\title{
Distribution of antimicrobial lipopeptides in Bacillus and Pseudomonas spp., two genera with antagonistic effects against plant pathogens
}

by

Rowida Mohamed

A thesis submitted to the Faculty of Graduate and Postdoctoral Affairs in partial fulfillment of the requirements for the degree of

Master of Science

in

Chemistry

(Concentration in Food Science and Nutrition)

Carleton University

Ottawa, Ontario

(C) 2015, Rowida Mohamed 


\begin{abstract}
Suppressive soils, composts, and compost teas have previously shown inhibitory effects against plant disease. A major reason for this suppressiveness has been their beneficial microbial populations. The present study was carried out to investigate the inhibitory activity of forty bacteria isolated from these three sources against the mycelial growth of six plant pathogens. Thirty-eight isolates inhibited at least one of the pathogens whereas sixteen of the isolates inhibited all the pathogens (36\% average inhibition). Crude lipopeptides extracts were precipitated from bacterial liquid cultures. All tested lipopeptide samples inhibited the mycelial growth or conidial germination of at least one of the pathogens. Known antimicrobial lipopeptides in selected samples were identified by LC-MS. Results showed that all Bacillus and Bacillus-related spp. produced one or more lipopeptides from the fengycin, iturin, and surfactin families. In addition, certain Pseudomonas spp. produced lipopeptides from the amphisin and putisolvin families.
\end{abstract}




\section{Acknowledgments}

It is with immense gratitude that I acknowledge the support and help of my supervisor, Dr. Tyler Avis. He has been the pivotal point of my academic growth. Dr. Avis' passion and positive attitude towards learning and teaching science has encouraged my educational aspirations. I sincerely thank him for allowing me to pursue research in his lab for five years.

I would also like to express my deep and sincere gratitude to my co-supervisor, Dr. Apollinaire Tsopmo. A great amount of his valuable time was used to give me constructive suggestions to complete this thesis. More specifically, I appreciate his warm and gentle approach to any issues that occurred with the data.

As well, I wish to acknowledge each of my past and present colleagues from Dr. Avis' lab for their friendly and open attitudes that made the lab a pleasant working environment.

And, I wish to thank the Chemistry Department and each of my undergraduate professors at Carleton University. A special thanks to Professor J. David Miller, and his lab members, for allowing the use of his specialized equipment.

Additionally, I would like to thank the Natural Sciences and Engineering Research Council (NSERC) of Canada, Les Fraises de l'Île d'Orléans, and Berger Peat Moss for funding this research project.

Finally, I want to appreciate my family and friends for their continuous interest in my research-oriented life. More specifically, I owe my most loving thanks to my mother. Without her encouragement, support, and assistance, this work would not have been completed work. Lastly, my thesis is dedicated to my nephew, Yasseen. 


\section{Table of contents}

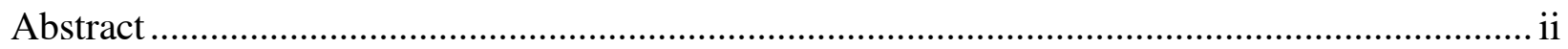

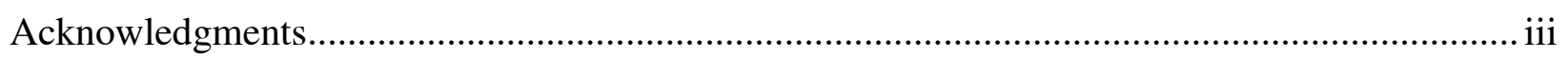

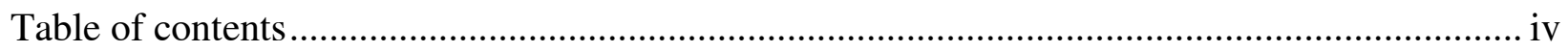

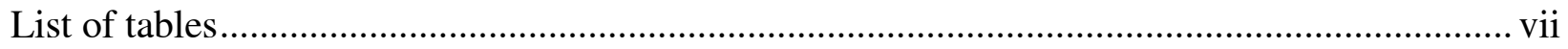

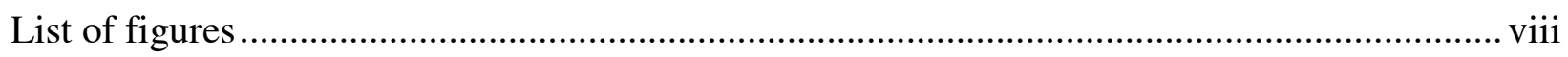

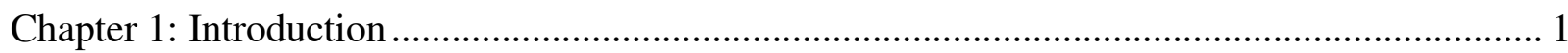

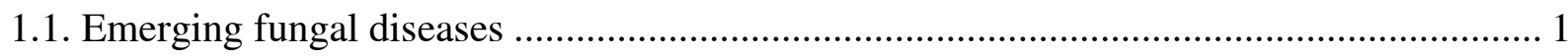

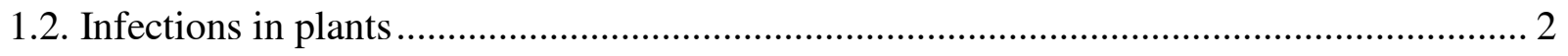

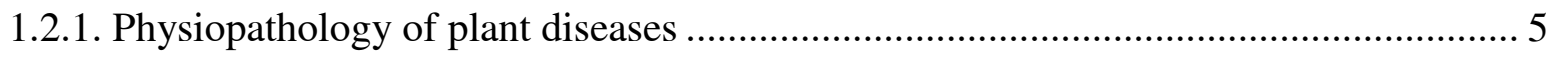

1.2.1.1. Alternaria solani ...................................................................................... 5

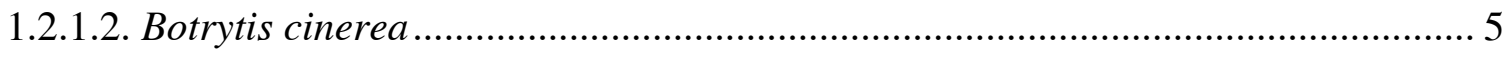

1.2.1.3. Fusarium sambucinum .......................................................................... 6

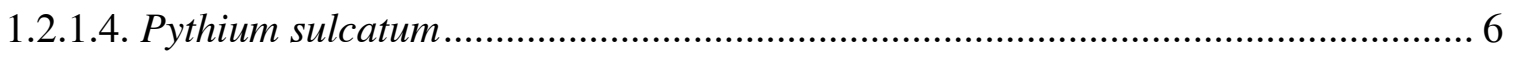

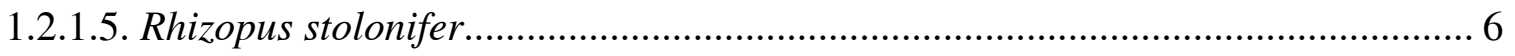

1.2.1.6. Verticillium dahliae .................................................................................... 7

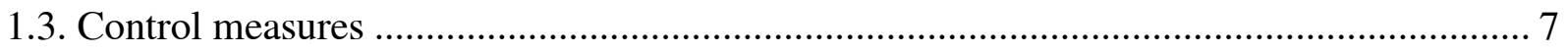

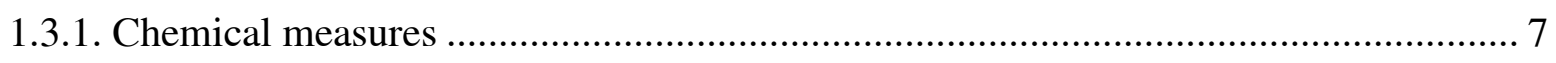

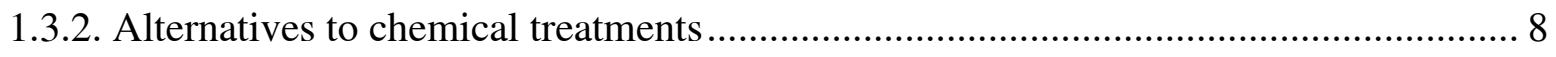

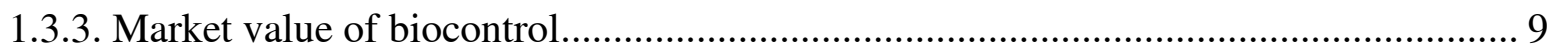

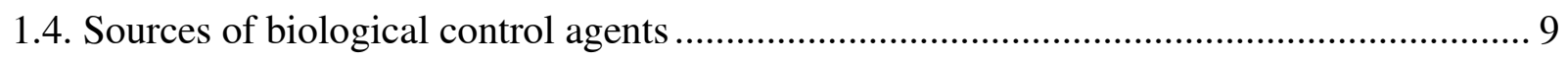

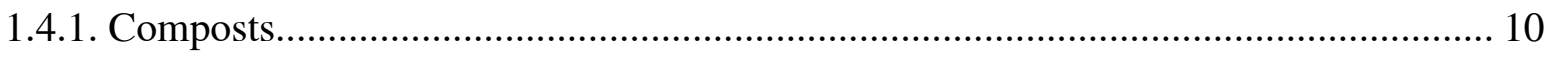

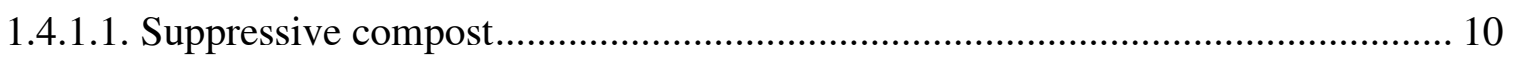

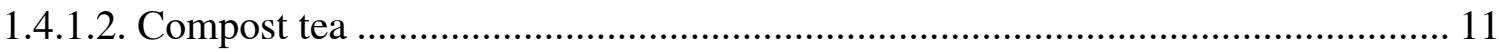




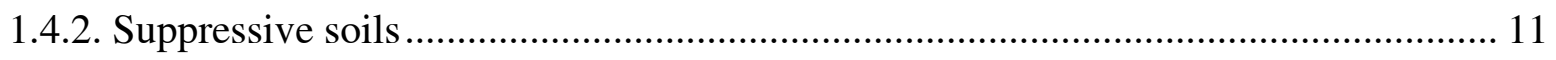

1.5. Antimicrobial metabolites from microorganisms …….................................................... 12

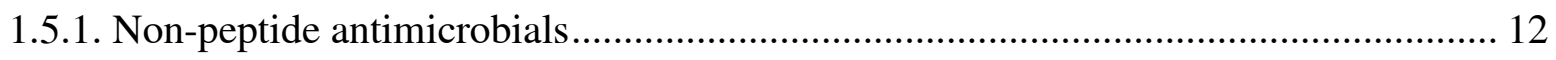

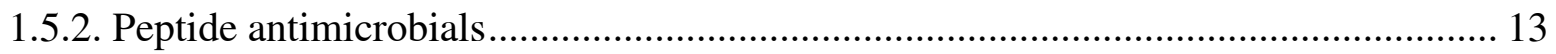

1.5.2.1. Cyclic lipopeptides (CLP) ............................................................................ 14

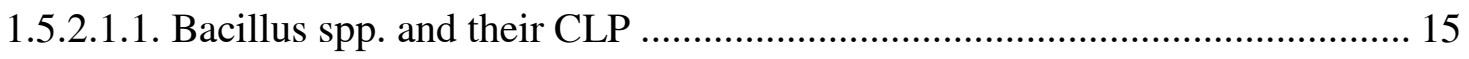

1.5.2.1.2. Pseudomonas spp. and their CLP............................................................ 19

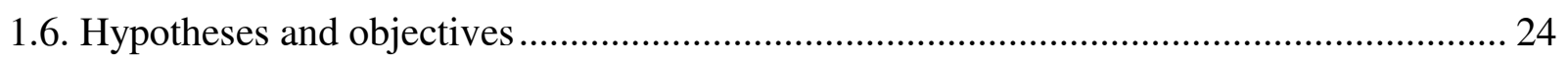

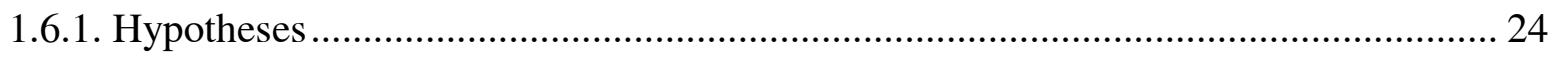

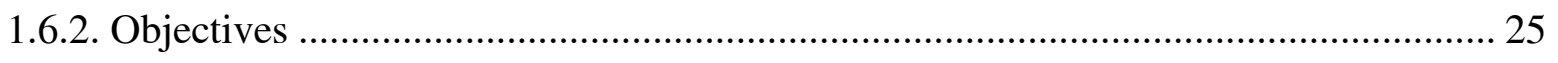

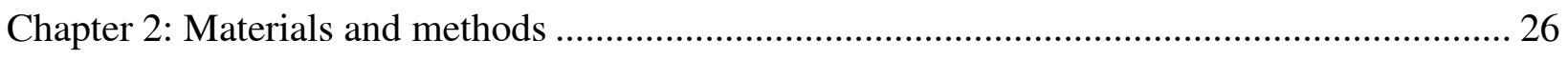

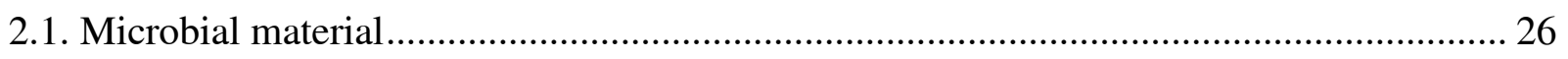

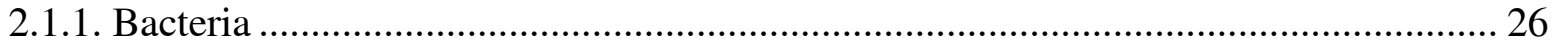

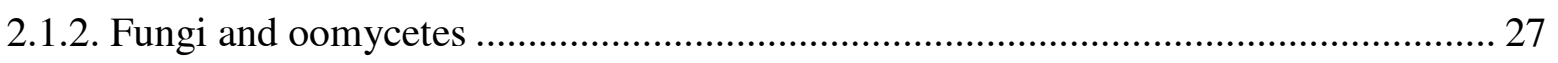

2.2. Antagonistic activity of bacterial isolates against pathogens .......................................... 29

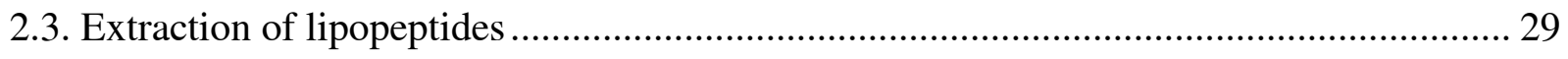

2.3.1. Preparation of medium optimized for lipopeptide production (MOLP) ..................... 29

2.3.2. Bacterial growth and recovery of cell-less culture medium ..................................... 30

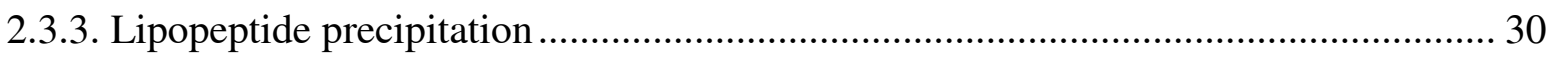

2.4. Antimicrobial activity of the lipopeptide extracts ......................................................... 30

2.4.1. Effect of crude lipopeptide extracts on mycelia growth ............................................ 31

2.4.2. Effect of crude lipopeptide extracts on spore germination ....................................... 32

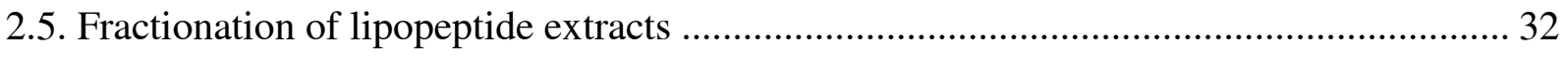


2.6. Characterization of lipopeptides in bacterial extracts

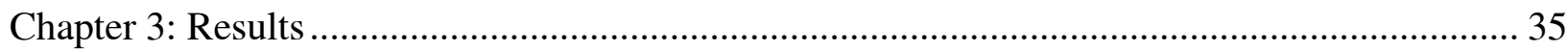

3.1. Antagonistic activity of bacterial isolates against fungi ................................................... 35

3.2. Effect of lipopeptide extracts on mycelial growth ........................................................... 43

3.3. Effect of lipopeptide extracts on conidial germination...................................................... 48

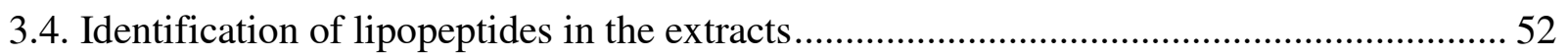

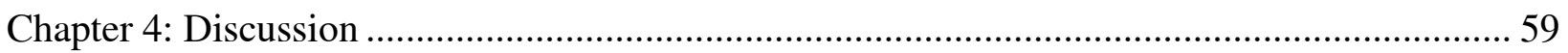

4.1. Evaluation of various bacterial antagonists through general plate inhibition assays......... 60

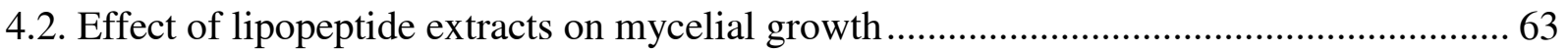

4.3. Antifungal activity of lipopeptide extracts on fungal pathogen conidial germination ...... 65

4.4. Correlation of lipopeptides extracts and inhibitory effects ................................................ 66

4.5. Identification of lipopeptides in extracts from bacterial antagonists ................................. 66

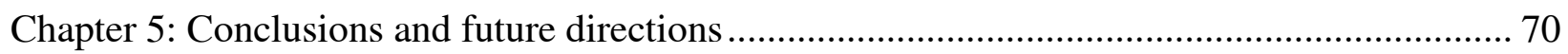

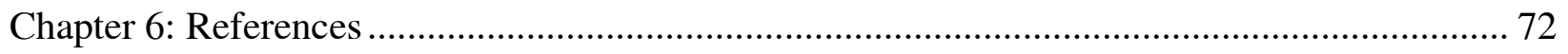

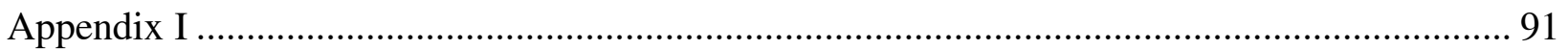




\section{List of tables}

Table 1. Taxonomic classification of the plant pathogens used in this study 3

Table 2. Examples of amino acid composition and fatty acyl group length of the Bacillus spp. lipopeptide families surfactin, iturin, and fengycin 18

Table 3. Primary structure of lipopeptide families and representative variants produced by Pseudomonas spp

Table 4. In vitro inhibitory activities of forty bacterial isolates from composts, compost tea, and soil against six pathogens: Alternaria solani, Botrytis cinerea, Fusarium sambucinum, Pythium sulcatum, Rhizopus stolonifer and Verticillium dahliae

Table 5. In vitro inhibitory activities of lipopeptide extracts from Pseudomonas arsenicoxydans F9-7, Pseudomonas koreensis F9-9, Pseudomonas proteolytica F9-10, Pseudomonas moraviensis F9-11, Bacillus subtilis B9-5, B9-14, CU12, F9-2, F9-8, F9-12, IC10, M9-7, and M9-9, and Bacillus badius M9-20 on the mycelial growth of Alternaria solani, Botrytis cinerea, Fusarium sambucinum, Pythium sulcatum, Rhizopus stolonifer and Verticillium dahliae ...... 46

Table 6. In vitro inhibitory activities of lipopeptide extracts from Pseudomonas arsenicoxydans F9-7, Pseudomonas koreensis F9-9, Pseudomonas proteolytica F9-10, Pseudomonas moraviensis F9-11, Pseudomonas libanensis F9-13, Bacillus subtilis isolates B9-5, B9-14, CU12, F9-2, F9-8, F9-12, IC10, M9-7, M9-9, and Bacillus badius M9-20 on conidial germination of Alternaria solani, Botrytis cinerea, Fusarium sambucinum, Rhizopus stolonifer and Verticillium dahliae. 50

Table 7. Fengycin homologs detected by LC-MS in Bacillus and Bacillus-related species .... 55

Table 8. Iturin homologs detected by LC-MS in Bacillus and Bacillus-related species 56

Table 9. Surfactin homologs detected by LC-MS in Bacillus and Bacillus-related species..... 57

Table 10. Amphisin and putisolvin homologs detected by LC-MS in Pseudomonas species.. 58 


\section{List of figures}

Figure 1. Worldwide reporting trends in emerging fungal diseases, (a) an increase in alerts concerning fungal infections in plants and animals in the past few decades and (b) the global distribution of alerts in the emergence of fungal pathogens (plants and animals) (Fisher et al., 2013).

\section{1}

Figure 2. Symptoms and signs of plant diseases in different food crops (a) Alternaria solani causal agent of early blight of tomato fruit; (b) Botrytis cinerea causal agent of gray mold of strawberries; (c) Fusarium sambucinum causal agent of potato dry rot; (d) Pythium sulcatum causal agent of cavity spot in carrot roots; (e) Rhizopus stolonifer causal agent of Rhizopus rot of tomato fruit; (f) Verticillium dahliae causal agent of Verticillium wilt in strawberry plants.. 4

Figure 3. Structure of two non-peptide biocontrol (a) 2,3-dihydroxybenzoyl-glycine and (b) pyrrolnitrin

Figure 4. Structural representation of three families of lipopeptides produced by Bacillus spp. (a) surfactin (b) fengycin and (c) iturin 17

Figure 5. Representative structures of cyclic lipopeptides families produced by Pseudomonas spp. (a) viscosin, (b) amphisin, (c) putisolvin, (d) syringomycin.....

Figure 6. Flow chart the experimental process for investigating antagonistic effects of bacterial isolates and identifying the presence of lipopeptide compounds

Figure 7. Relative inhibitory activity of pathogens mycelial growth by bacterial isolates from Bacillus and Bacillus-related spp., Pseudomonas spp. and other isolates. Values were calculated from Table 4. Relative inhibitory activity $=$ [(growth of mycelial radius control)-(growth of mycelial from the treatment) $] /$ (growth of mycelial radius control)

Figure 8. Correlation between reduction of mycelial growth and conidial germination (\% inhibition) of the pathogens. Data were obtained from Table 6 and 7. Presented data are means from three biological repeats 
Figure A1. Lipopeptides families produced by Bacillus subtilis CU12. A. Chromatogram showing the three families of lipopeptides; B. Mass spectrum of iturin, $m / z=1084$ and 1099; C. Mass spectrum of fengycin, $m / z=1462,1476,1490$; D. Mass spectrum of surfactin $m / z=1008$,

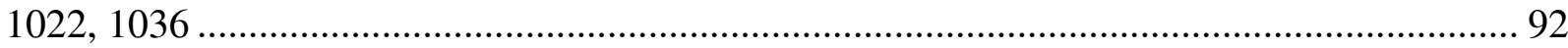

Figure A2. Lipopeptides families produced by Bacillus megaterium B9-9B. A. Chromatogram showing the two families of lipopeptides; B. Mass spectrum of surfactin, $m / z=1008,1022$, 1036; C. Mass spectrum of fengycin, $m / z=1476,1490,1492,1506$

Figure A3. Lipopeptides families produced by Pseudomonas moraviensis F9-11. A. Chromatogram showing the three families of lipopeptides; B. Mass spectrum of amphisin, $\mathrm{m} / \mathrm{z}$ $=1340,1354,1368,1382 ; \mathrm{C}$. Mass spectrum of putisolvin, $m / z=1383$ and 1397 94 


\section{Chapter 1: Introduction}

\subsection{Emerging fungal diseases}

In the last few decades, an increase in crop diseases, caused by emerging species of fungi in plants, was observed around the globe from 1995 to 2010 leading to major economic losses and starvation (Fisher et al., 2013; Figure 1). Fungal infections presently destroy at least 125 million tonnes of the top five food crops (rice, wheat, maize, potatoes, and soybeans) (Fisher et al., 2013). Because 59 percent of calories consumed by humans are derived from just four essential plant species (rice, wheat, maize, and potatoes), fungal diseases in these staple crops can catastrophically threaten local and global food security (Strange and Scott, 2005; Vurro et al., 2010). The ability of many plant pathogens, including fungi, to persist in the environment for long periods of time makes it difficult to eradicate fungal diseases, resulting in an economic burden to agricultural communities (Fisher et al., 2013, Figure 1b).

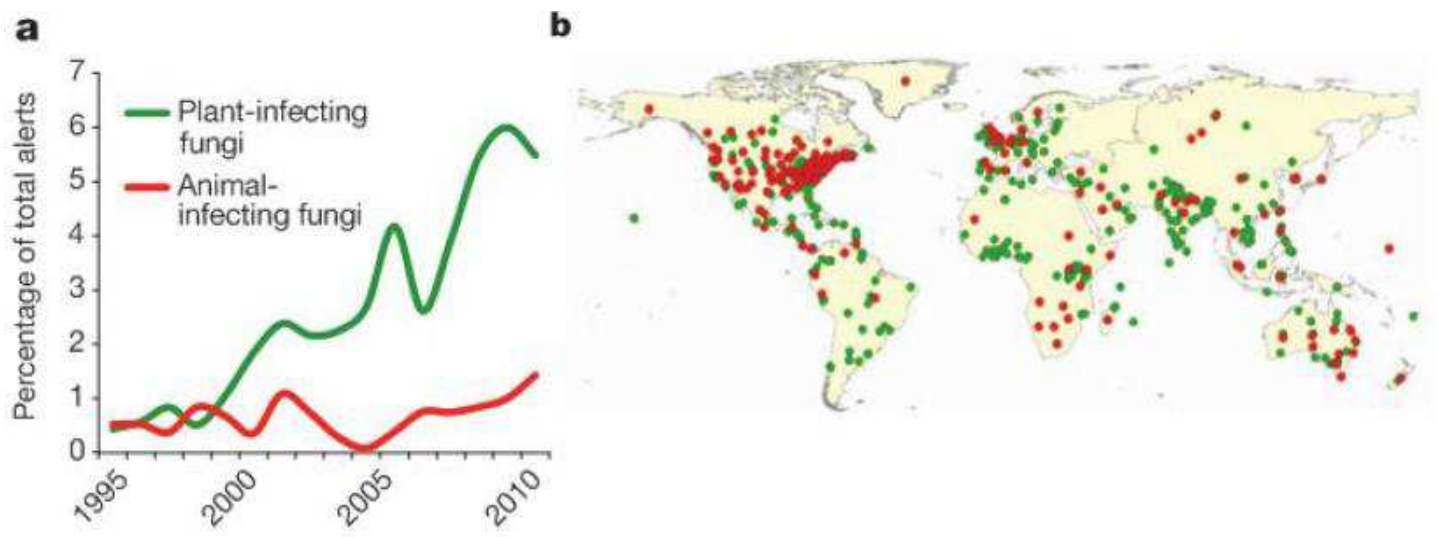

Figure 1. Worldwide reporting trends in emerging fungal diseases, (a) an increase in alerts concerning fungal infections in plants and animals in the past few decades and (b) the global distribution of alerts in the emergence of fungal pathogens (plants and animals) (Fisher et al., 2013). 


\subsection{Infections in plants}

Consumption of fruits and vegetables products has dramatically increased in the United States by more than $30 \%$ during the past few decades. It is also estimated that about $20 \%$ of all fruits and vegetables produced is lost each year to spoilage, representing 18.9 billion pounds of lost produce (Barth et al., 2009). Fungi are the predominant pathogens in plants (Avis, 2007) including fruits and vegetables. Some common fruit and vegetable pathogens of economic importance are Alternaria solani Sorauer, Botrytis cinerea Pers., Fusarium sambucinum Fuckel, Rhizopus stolonifer (Ehrenb.: Fr.) Vuill. and Verticillium dahliae Kleb. These pathogens are all fungi. In addition to these fungal pathogens, Pythium sulcatum is another important vegetable pathogen that was classified previously as a fungus, but has been reclassified and currently belongs to the oomycete class in the Chromalveolata kingdom. Taxonomic classification of the plant pathogens used in this thesis are listed in Table 1. These pathogens infect the host plants and cause symptoms such as: rotting, spotting, drying, wilting, and discoloration (Figure 2) as described in the following sections. 
Table 1. Taxonomic classification of the plant pathogens used in this study

\begin{tabular}{|c|c|c|c|c|c|c|}
\hline Kingdom & \multicolumn{5}{|c|}{ Fungi } & Chromalveolata \\
\hline Class & Dothideomycetes & Leotiomycetes & Sordariomycetes & Zygomycetes & Sordariomycetes & Oomycetes \\
\hline Subclass & Pleosporomycetidae & N/A & Hypocreomycetidae & N/A & Hypocreomycetidae & N/A \\
\hline Order & Pleosporales & Helotiales & Hypocreales & Mucorales & Incertae & Pythiales \\
\hline Genus & Alternaria & Botrytis & Fusarium & Rhizopus & Verticilium & Pythium \\
\hline Species & Solani & cinerea & sambucinum & stolonifer & dahliae & sulcatum \\
\hline
\end{tabular}

All information was obtained from the National Center for Biotechnology Information (NCBI, 2015) 
(a)

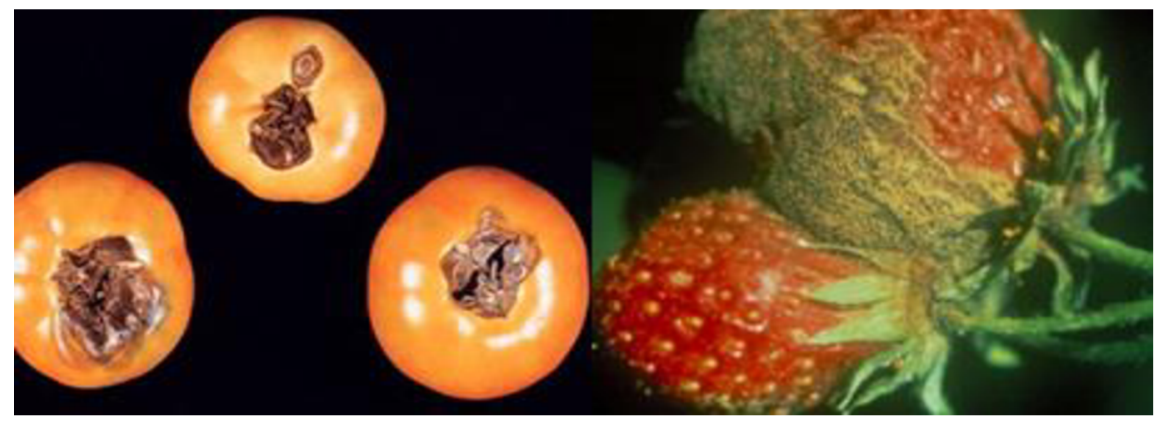

(c)

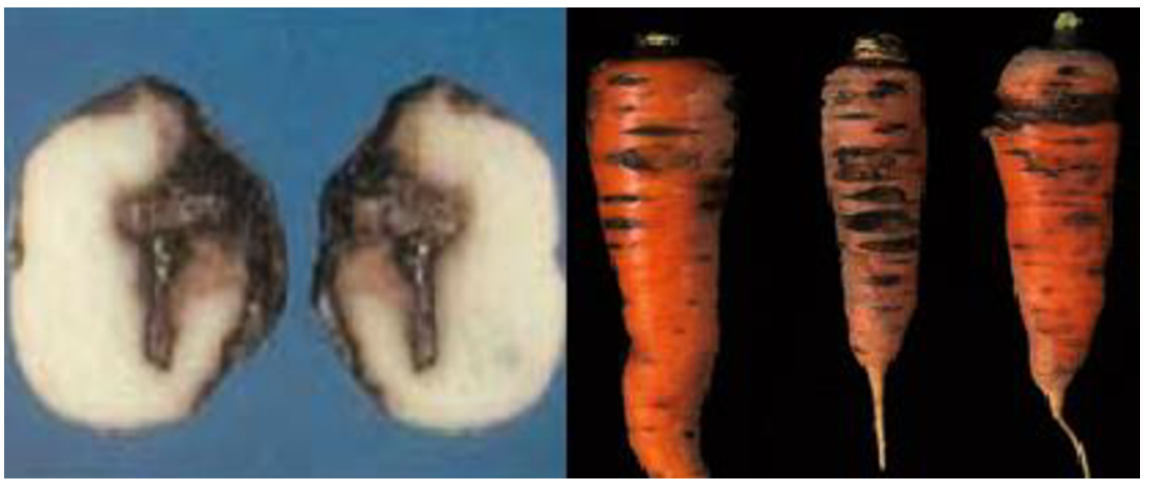

(e)

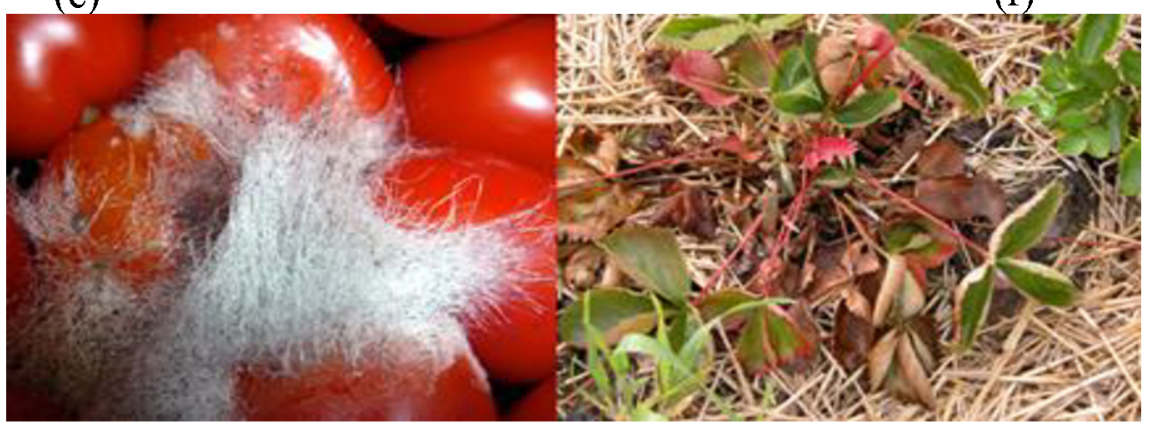

Figure 2. Symptoms and signs of plant diseases in different food crops (a) Alternaria solani causal agent of early blight of tomato fruit (Stevenson, 1993); (b) Botrytis cinerea causal agent of gray mold of strawberries (Caltex Mold Services, 2007); (c) Fusarium sambucinum causal agent of potato dry rot (Loria, 1993); (d) Pythium sulcatum causal agent of cavity spot in carrot roots (Davison and McKay, 2003); (e) Rhizopus stolonifer causal agent of Rhizopus rot of tomato fruit (Boyer, 2015); (f) Verticillium dahliae causal agent of Verticillium wilt in strawberry plants (Horst, 2001). 


\subsubsection{Physiopathology of plant diseases}

Most plant diseases are caused by fungi and fungus like pathogens, compare to losses to other classes of pathogens such bacteria and viruses. In this study, we focused on six plants pathogens that cause loss to important crops (Fisher et al., 2013) as described in the following sections.

\subsubsection{Alternaria solani}

Alternaria solani causes blight disease in tomatoes and potatoes, and produces various phytotoxins such as solanapyrones (Hideaki et al., 1998). In tomatoes, infected plants develop dark spots on older lower leaves and blackish-brown lesions with a yellow halo appear on older leaves and stems. Although these lesions are initially circular, they can become angular when they grow between leaf veins. Infection of the tomato fruit normally occurs through the calyx and lesions of a considerable size can be found on the fruit (Kemmitt, 2002) (Figure 2a). It is also a major concern for potato growers because the pathogen can persist and survive in the soil between crop harvests and can therefore be present to infect the next crop (Stevenson et al., 2001).

\subsubsection{Botrytis cinerea}

Botrytis cinerea is a phytopathogenic fungus which causes gray mold (Figure 2b) or Botrytis blight and is found in more than 200 host plant species. The fungus mostly affects vegetable and fruit crops such as grapes, strawberries and tomatoes (Nakajima and Akutsu, 2013). 


\subsubsection{Fusarium sambucinum}

Fusarium sambucinum is one of the most common fungi that causes dry rot of potatoes (Figure 2c) in Europe and North America (Ripperger et al., 1975). This pathogen produces many mycotoxins (Bojanowski et al., 2013) such as trichothecene and the mycotoxin 4,15diacetoxyscirpenol (DAS), which has teratogenic effects in animals (Sokolova and Voznesenskiǐ, 2011).

\subsubsection{Pythium sulcatum}

Pythium sulcatum is the most common cause of cavity spot in carrot roots (Davidson and McKay, 2003). Pythium sulcatum is not a fungus. It is a fungus-like organism from the oomycete class (kingdom Chromalveolata). The hyphae of Pythium have the ability to penetrate the carrot roots through cracks produced by the outgrowth of the lateral roots or other wounds (Zamski and Peretz, 1995). Characteristic symptoms of the disease are a cooked-tuber texture, while a discolored water-soaked area appears around the wound (Figure 2d). The rotted tissues are spongy and extremely watery (Du Toit and Derie, 2014). Diseased tissues are separated from healthy tissue by a dark line and affected tissues change their color from gray, to brown, and finally, to black when exposed to air (Christ, 1998).

\subsubsection{Rhizopus stolonifer}

Rhizopus stolonifer is a heterotrophic, thread-like mold. Rhizopus stolonifer produces a mass of mycelium, the vegetative filaments of the fungus, and a characteristic fruiting structure that contains spores. Rhizopus stolonifer breaks down soft fruits such as papaya and tomatoes (Figure 2e) (Fan and Tian, 2000). 


\subsubsection{Verticillium dahliae}

Verticillium dahliae is one of the main wilt causing fungi in numerous plants including strawberries (Figure 2f), potatoes, tomatoes, mint, and other plants (Horst, 2001). Verticillium dahliae is a conidia-forming fungus, producing one-celled, hyaline, fibrose to ellipsoid conidia at tips of whorled branches and separating readily forming tips. Verticillium dahliae is the only species of the genus forming microsclerotia, which help differentiate this species from other Verticillium spp. such as V. albo-atrum (Isaac, 1967).

\subsection{Control measures}

\subsubsection{Chemical measures}

The most common strategies available to manage plant diseases are chemical based methods (compounds with fungicidal or oomycetal activity). For example, although costly, fumigation with chemical biocides (which control fungi, nematodes, and weeds) are practically the only economically viable measure available to growers to control plant pathogens in some crops such as strawberries. However, these chemical methods may have major negative impacts on the environment and human health (Bae et al., 2008). Indeed, pesticides have been linked to a wide range of human health hazards, ranging from short-term impacts such as headaches and nausea to chronic impacts like cancer, reproductive harm, and endocrine disruption. Impacts of pesticides on the environment are also well known and some pesticides were shown to be toxic to living organisms. Some pesticides can accumulate in water systems, pollute the air, and in some cases have other dramatic environmental effects (Toxic Action Center, 2012). 
Furthermore, pesticide use can lead to the development of resistant plant pathogen strains (Trivedi, 2007).

\subsubsection{Alternatives to chemical treatments}

Many alternatives to chemical control measures seem promising. These alternative methods include: host resistance, crop rotation, and biological control (or biocontrol). Host resistance is the use of plants bred with improved genetic ability to stave off disease. A drawback of this method is that selection of resistance traits is delayed until later generations.

Rotation of crops with plants that are not susceptible to the particular disease (Martin and Bull, 2002) is another alternative. However, some plant pathogens persist for many years as they can survive extreme environmental conditions (Gomez-Alipzar, 2001). Thus, some pathogens may still be present when the main crop is returned to the field if the rotation was not sufficiently long (Njoroge et al., 2009).

In addition to the previous methods, biological control of pathogens with antagonists has been intensively investigated (Van Loon and Glick, 2004). According to Baker and Cook (1974), biocontrol is defined as "the reduction of inoculum density or disease producing activities of a pathogen or parasite in its active or dormant state, by one or more organisms accomplished naturally or through manipulation of the environment, host, or antagonist or by mass introduction of one or more antagonists". Biocontrol has different modes of action including (i) parasitism i.e., the ability to penetrate through the fungal tissue and produce metabolic substance (such as digestive enzymes) that damage the tissues of the pathogen; (ii) competition for nutrients and space; (iii) antibiosis i.e., the production of volatile and or non-volatile antimicrobial compounds; and (iv) induced resistance i.e., the ability of a beneficial 
microorganism or other elicitor to induce and/or enhance the host plant's ability to defend itself through plant defense mechanisms (Trivedi, 2007).

\subsubsection{Market value of biocontrol}

The global consumer market demands high quality food with reduced pesticide exposure. A recent study was conducted to report the state of the agricultural inoculants market (Markets and Markets, 2013). Agriculture inoculants are formulations containing one or more beneficial microorganism strains (or species), which help plants develop, directly or indirectly. They include plant growth promoting microorganisms, biocontrol agents, and plant resistance

stimulants. The global market for agricultural inoculants was valued at \$232 million in 2013 (Markets and Markets, 2013). This market is projected to grow at 9.5\% from 2014 to reach $\$ 398$ million by 2019. North America dominated in sales of these products in 2013. The Latin American demand for these inoculants are projected to emerge as the fastest growing market segment at rate of $\sim 10 \%$ from 2014 to 2019 (Markets and Markets, 2013). This indicates that biological control products are growing rapidly, and there is still a need to develop and optimize naturally-derived products.

\subsection{Sources of biological control agents}

Microorganisms that naturally antagonise plant pathogens and suppress plant diseases are found in many environmental materials such as compost, compost tea, and suppressive soils. 


\subsubsection{Composts}

According to Hoitink (1980) "composting is the breakdown of organic waste materials by mixed populations of microorganisms in a thermophilic aerobic environment". Compost has agricultural value because it improves the structure and moisture-retention properties of soil and provides plants with nutrients. Composts produced from various agricultural wastes, such as plant residues and animal manure (Chen et al., 1988; Inbar et al., 1991) have also been shown to suppress soil-borne plant pathogens (Hoitink et al., 1997; Cotxarrera et al., 2002). Disease suppression in these composts are in part attributed to their microbial populations (Avilés et al., 2011). Two main uses of composts for disease control are (i) the direct use of suppressive composts and (ii) the use of compost tea.

\subsubsection{Suppressive compost}

A suppressive compost can be defined as a compost providing reduced disease development in the presence of a pathogen and a susceptible plant. Plant disease suppression can be the direct result of the activity of antagonistic microorganisms, which naturally colonize compost (Mandelbaum et al., 1988). For example, compost from marine waste has been shown to increase crop yields and suppress plant diseases caused by several plant pathogens (Niisawa et al., 2008). This compost was also found to contain beneficial Bacillus spp., which had the ability to inhibit pathogenic Fusarium spp. (Niisawa et al., 2008). Other work on olive and grape marc compost showed that this compost consistently suppressed Fusarium wilt of tomatoes and Rhizoctonia damping-off (Avilés et al., 2011). 


\subsubsection{Compost tea}

Compost teas are "fermented watery extracts of composted materials that are used for their ability to decrease plant diseases" (Litterick et al., 2004). The resulting liquid can then be applied as a soil or foliar application (Scheuerell and Mahaffee, 2002). Compost tea is highly heterogeneous in nature and is a source of many microorganisms that compete with the pathogens, thereby reducing disease. Compost teas act on pathogens by inhibiting their spore germination, by increasing the amount of benign microorganisms that produces antifungal compounds, and/or by inducing systemic and local acquired resistance (Deepthi and Reddy, 2013). The disease suppressive ability of compost teas is mainly because of the presence of beneficial microorganisms (Dionne et al., 2012; On et al., 2015). For example, compost teas showed successful suppression of tomato plant pathogens because of the beneficial microorganisms they contained such as fluorescent Pseudomonas spp. and Actinomycetes (Koné et al., 2010). Bacteria of the genera Bacillus, Pseudomonas and Serratia, and filamentous fungi of the genus Trichoderma are commonly isolated antagonists from compost teas (Hoitink et al, 1991; Hoitink et al., 1997) and their antagonistic activity will be discussed in section 1.5.

\subsubsection{Suppressive soils}

A suppressive soil is one in which pathogens, although present, do not cause the expected damage due to the inhibitory activities of the soil (Termorshuizen and Jeger, 2008). Among the most reported causes for the disease suppressiveness in these soils is the presence of beneficial microorganisms (Martinez et al., 2002). Suppressive soils therefore provided a wealth of microbial resources with potential to be utilized as biological control agents of plant pathogens. 
Recently, B. subtilis CU12 was isolated from an agricultural field with a history of low plant disease and the bacterium showed antagonistic activities against plant pathogens such as A. solani, B. cinerea, F. sambucinum and P. sulcatum (Wise et al., 2012). Furthermore, other researchers isolated Bacillus cereus, Cellulomonas fimi, Kocuria varians, Pseudomonas putida, Rhodococcus erythropolis and Rhodococcus globerulus from different suppressive soils, which exhibited in vitro reduction of mycelial growth of Helminthosporium solani (Martinez et al., 2002). Among the antagonistic bacteria isolated from suppressive soils Bacillus spp. and Pseudomonas spp. are among the most common and well-studied (Trotel-Aziz et al., 2007) and will be the focus of the following sections.

\subsection{Antimicrobial metabolites from microorganisms}

As previously mentioned, several reports showed that microbial antagonists isolated from compost, compost teas and suppressive soils can play a role in the suppression of plant diseases (Avilés et al., 2011). Many studies showed that this suppression is linked, in part, to the production of antimicrobial compounds. For example, antimicrobial metabolites are linked to suppression of plant disease such Armillaria root rot by Trichoderma viride and Pythium and Rhizoctonia damping-off, stem and root rot by Pseudomonas fluorescens (Zintani, 2005). There are numerous types of these antimicrobial compounds that are generally classified into two groups: peptide and non-peptide antimicrobials.

\subsubsection{Non-peptide antimicrobials}

Pseudomonas spp. are among the most active and dominant bacteria producing nonpeptide antimicrobials such as pyrrolnitrin (Figure 3), pyoluteorin and phenazine-1-carboxylate. 
Previous work showed that these antimicrobial compounds are linked to the suppression of plant diseases (Duffy and Defago, 1999). Similarly, bacteria producing siderophores, compounds that mediate competition for iron, have emerged as a sustainable approaches for integrated plant disease management (Sayyed and Patel, 2011). A study showed that Pseudomonas spp. inhibited the growth of black root rot of tobacco caused by Chalara elegans and that suppression was linked to the production of siderophore (Voisard et al., 1994). Bacillus subtilis has also been shown to produce the siderophore 2,3-dihydroxybenzoyl-glycine (Figure 3), which is implicated in the suppressive activity toward a wide spectrum of plant pathogens (Leong, 1986). Furthermore, B. subtilis strain CU12 showed the production of 3-hydroxypropionaldehyde compounds with inhibitory properties against mycelial growth of $A$. solani, $B$. cinerea, and $P$. sulcatum (Wise et al., 2012). Also reported by Hamdache et al. (2011) showed that Bacillus spp. produce diverse groups of none-peptide metabolites with inhibitory activities such as polyene antimicrobials.

(a)

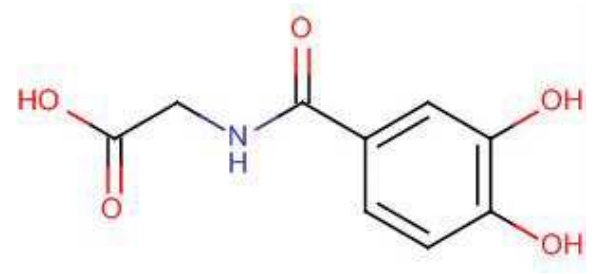

(b)<smiles>O=[N+]([O-])c1c(Cl)cccc1-c1c[nH]cc1Cl</smiles>

Figure 3. Structure of two non-peptide biocontrol (a) 2,3-dihydroxybenzoyl-glycine and (b) pyrrolnitrin (Adapted from the National Library of Medicine Database, 2015).

\subsubsection{Peptide antimicrobials}

Antimicrobial peptides, also known as peptide antibiotics, have been further defined in the past half-century. There are two classes of peptides: non-ribosomally synthesized peptides 
and ribosomally synthesized peptides. Antimicrobial peptides are largely produced by bacteria and other species as major components of the natural host defense system (Hancock and Chapple, 1999). Antimicrobial peptides are exceptional compounds due to their significant role in the health of plants. Living organisms secrete a wide range of antimicrobial peptides produced through ribosomal (defensins and small bacteriocins) or non-ribosomal synthesis (peptaibols,

cyclopeptides and pseudopeptides). Many antimicrobial peptides have shown high levels of protection against plant diseases (Montesinos, 2007). For examples, B. subtilis isolates was shown to control Pythium damping-off on tomatoes and its inhibitiory effects were attributed to the production of the peptide antimicrobial mycosubtilin (Leclère et al., 2005).

\subsubsection{Cyclic lipopeptides (CLP)}

Among peptide antimicrobials are a subcategory named cyclic lipopeptides (CLPs), which are biosynthesized by non-ribosomal peptide synthetases (NRPSs), which, unlike the ribosome, often utilize both regular and non-proteinogenic amino acids as substrates (Bockus et al., 2013). The general structure of CLP comprises a lactone or lactam ring (Bruner et al., 2002) with a fatty acyl tail. CLPs are characterized by structural diversity arising from differences in the carbon length $\left(\mathrm{C}_{6}-\mathrm{C}_{18}\right)$, composition of the fatty acid moiety ( $\beta-\mathrm{OH}$ groups, iso-, anteisomethyl branched forms) and from variations in the number of (2-25 AA), type of (basic, acidic, aromatic, aliphatic, cyclic, $\mathrm{OH} / \mathrm{SH}$-containing, $\alpha$ - or $\beta$-type), and configuration of (D, L) the amino acids in the peptide portion (Liu et al., 2008). The two major genera of bacteria that produce a wide range CLPs are Pseudomonas spp. and Bacillus spp. (Raaijmakers et al., 2010). In nature, antimicrobial biosynthesis by microorganisms can provide many different molecules (Schneider et al., 2009). Discovering and identifying which antagonists produce which 
antimicrobial compounds as well as the effect of these compounds in vitro and in vivo will provide a better understanding on how the antimicrobial and, ultimately, the antagonist will behave in the environment in terms of its biological control ability.

\subsection{Bacillus spp. and their CLP}

Bacillus spp. are typically Gram positive, rod-shaped, heterotrophic, and usually motile. Bacillus spp. produce three major families of CLPs: fengycin, iturin, and surfactin (Malfanova et al., 2012). Each lipopeptide family is further sub-divided based on amino acid composition. The CLPs produced by Bacillus spp. are some of the most powerful CLP with regard to their antifungal and biosurfactant activity (Ongena and Jacques, 2008; Jacques, 2011).

\subsection{Fengycin family}

Fengycins are a family of biologically active CLPs produced by various species of Bacilli, such as B. subtilis, B. cereus, B. amyloliquefaciens and B. globigii (Hu et al., 2007; Romero et al., 2007; Bie et al., 2009; Pyoung et al., 2010). The peptide portion of fengycins consist of 10 amino acids forming a peptide ring attached to a $\mathrm{C}_{14}-\mathrm{C}_{18}$ fatty acid chain (Figure 4b and Table 2) (Lang, 2002). Fengycin is synthesized non-ribosomally by peptide synthetases. The biosynthesis of fengycin requires five fengycin synthetases encoded by $f e n C, f e n D, f e n E$, fenA and $f e n B$ (Lin et al., 1998; Shu et al., 2002; Wu et al., 2007). Studies demonstrated that fengycins are implicated in the suppression of plant disease including preventing damping-off disease of bean seedlings caused by Pythium ultimum (Ongena et al., 2005). 


\subsection{Iturin family}

Iturins consist of 7 amino acids, which are linked to a $\mathrm{C}_{14}-\mathrm{C}_{17}$ fatty acid chain (Figure 6c and Table 3) (Lang, 2002). The iturin operon is composed of four open reading frames (ORFs): ituD, ituA, ituB, and $i t u \mathrm{C}$. The iturin family consists of many subgroups including iturin A, mycosubtilin, and bacillomycin, which showed effective antifungal activity against numerous plant pathogens (Thimon et al., 1995; Duitman et al., 1999; Tsuge et al., 2001; Moyne et al., 2004).

\subsection{Surfactin family}

Surfactins are the most commonly studied Bacillus lipopeptide family and their structures consist of a 7 amino acid cyclic sequence connected to a $\mathrm{C}_{13}-\mathrm{C}_{16}$ fatty acid chain (Figure 4a and Table 2) (Kakinuma et al., 1969). Surfactins contain $\beta$-hydroxyl fatty acid groups, usually $\beta$-hydroxytetradecanoic acid (Figure 4a and Table 2), synthesized by the srfA operon, and involve non-ribosomal peptide synthetases with ORFs that catalyse multifunctional enzymes for surfactin synthesis (Cosmina et al., 1993). Surfactins seem to also be key factors in the establishment of stable biofilms as they can inhibit the biofilm formation of other bacteria, thus protecting the host plant, as shown in Arabidopsis against Pseudomonas syringae (Bais et al., 2004). 


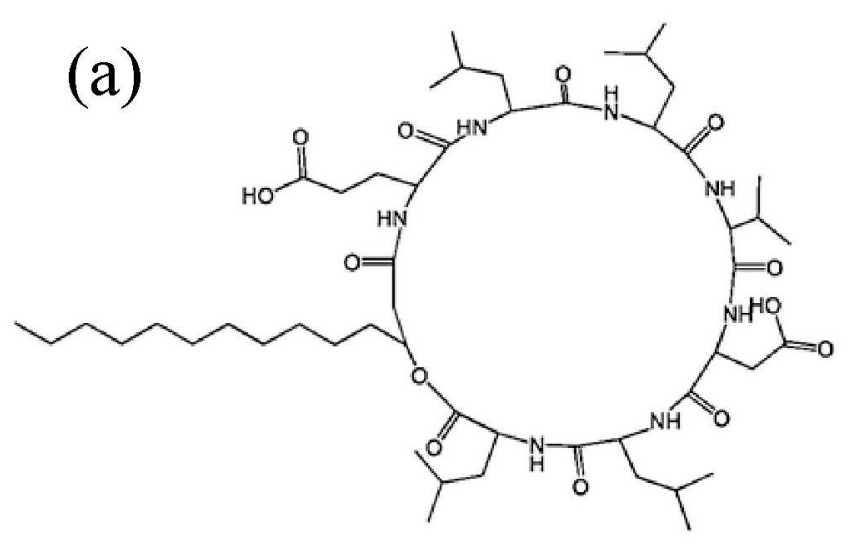

\section{(c)}

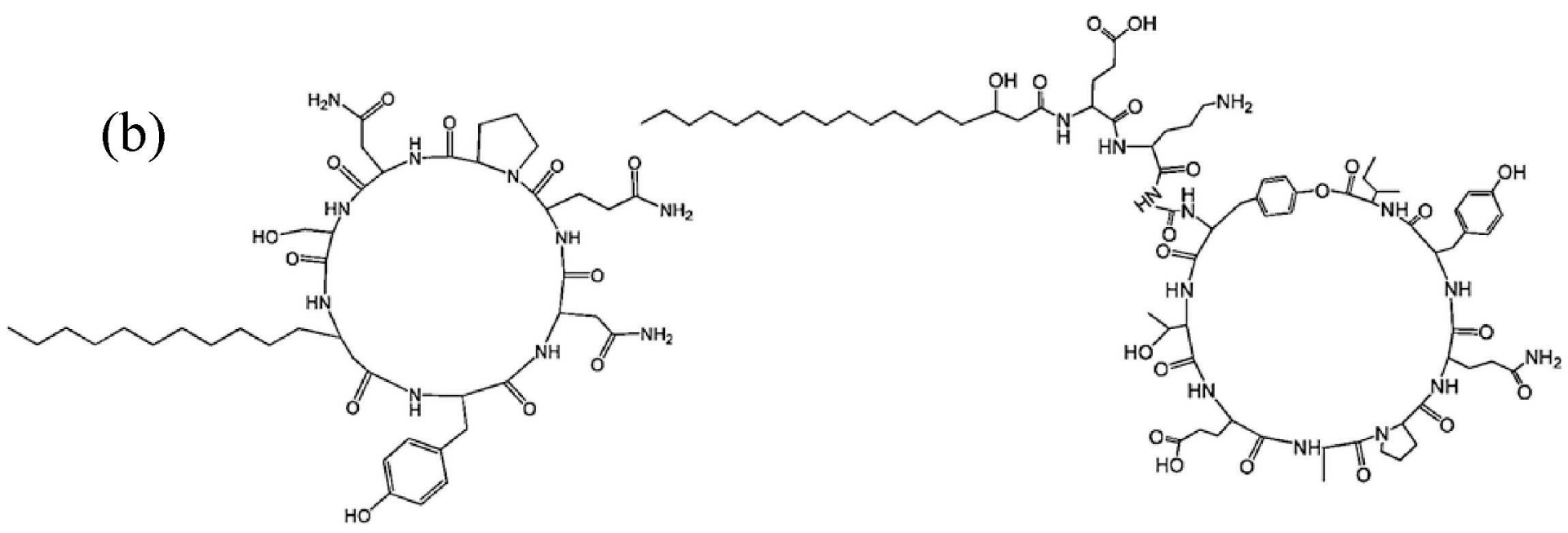

Figure 4. Structural representation of three families of lipopeptides produced by Bacillus spp. (a) surfactin (b) iturin and (c) fengycin (Ongena et al., 2005). 
Table 2. Examples of amino acid composition and fatty acyl group length of the Bacillus spp. lipopeptide families' surfactin, iturin, and fengycin. Structures were adapted from (Mondol et al., 2013).

\begin{tabular}{|c|c|}
\hline Lipopeptide family & Amino acid and fatty composition of variants and homologs* \\
\hline Surfactin & $\begin{array}{rr}\text { L-Ile } & \mathrm{C} \\
\text { L-Val } & \mathrm{B} \\
\mathrm{C}_{10-16} \mathrm{CHCH}_{2} \mathrm{CO}-\mathrm{L}-G l u-L-L e u-D-L e u-L-V a l-L-A s p-D-L e u-L-L e u & \mathrm{~A}\end{array}$ \\
\hline Iturin & $\mathrm{C}_{14-17} \mathrm{CHCH}_{2} \mathrm{CO}$-L-Asp \\
\hline Fengycin & 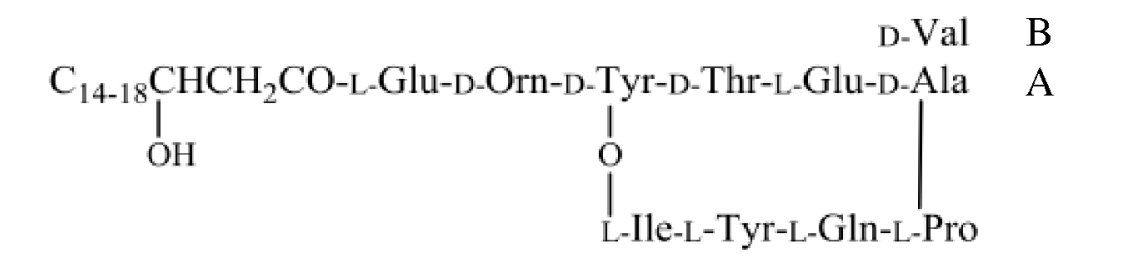 \\
\hline
\end{tabular}

*A, B, and $\mathrm{C}$ indicate different homologs of lipopeptides within each family Surfactin: (A) surfactin, (B) [Val7] surfactin, (C) [Ile7] surfactin Iturin: (A) iturin A-1, (B) iturin C-1 Fengycin: (A) fengycin A, (B) fengycin B 


\subsection{Pseudomonas spp. and their CLP}

Pseudomonas strains are one of the most intensively investigated sources of potential biocontrol agents. Among Pseudomonas spp., the most prevalent species that suppress plant diseases include $P$. aureofaciens, $P$. cepacia, $P$. chlororaphis, $P$. fluorescens and $P$. putida (Janisiewicz et al., 1997; 1992; Meena and Kanwar, 2015). Additionally, non-plant pathogenic isolates of $P$. syringae have been identified as useful biocontrol agents (Hildebrand et al., 1998). Strains of Pseudomonas spp. are typically Gram negative, chemoheterotrophic motile rods with polar flagella. They are non-spore forming and can produce pigments as defined by Palleroni et al. (1993). The extensive interest in Pseudomonas spp. is due in part to the production of a wide variety of metabolites, including enzymes, bacteriocins, toxins, antibiotics, and cyclic lipopeptides, which are a result of their interactions with multiple plant hosts (Haas and Défago 2005; Raaijmakers et al., 2006). The following sections include some of the most commonly reported families of antimicrobial CLP in Pseudomonas spp.

\subsection{Amphisin family}

Amphisins produced by Pseudomonas spp. have both biosurfactant and antifungal properties and inhibit plant pathogenic fungi (Sorensen et al., 2001). The primary structure of amphisin consists of 11 amino acids attached to 3-hydroxydecanoic acid (Figure 5b and Table

3). The structure of amphisin is distinguished by a cyclic peptide wrapping around a hydrogenbonded water molecule, which is important for its function (Raaijmakers et al., 2010). Amphisin is synthetized from non-ribosomal proteins encoded by large multifunctional peptide synthetases (Marahiel, 1997). Previous work showed that amphisin has the ability to suppress plant diseases caused by Pythium ultimum and Rhizoctonia solani (Nielsen et al., 2002). The 
amphisin family includes variants such as arthrofactin, tensin and lokisin (Table 3) (Sorensen et al., 2001).

\subsection{Putisolvin family}

Pseudomonas putida PCL1445 was found to produce two surface-active cyclic lipopeptides, putisolvins I and II. The ORF encoding the synthesis of the putisolvins bears amino acid homology to various lipopeptide synthetases (Kuiper et al., 2003). Putisolvins are produced by putisolvin synthetases designated as $p s o A, p s o B$ and $p s o V$ and were shown to encode NRPs (Dubern et al., 2008). Putisolvins I and II have a similar structure that consists of 12 amino acid polar peptide heads linked to hexanoic acid moiety (Figure 5c and Table 3). Putisolvins can inhibit the growth of microorganisms by inhibiting the formation of biofilms or breaking down previously formed biofilms (Kuiper et al., 2003).

\subsection{Syringomycin family}

Many strains of the bacterial pathogen Pseudomonas syringae, produce syringomycin lipopeptides (Segre et al., 1989). Syringomycin consists of 10 amino acid bonded to dodecanoic acid (Figure 5d and Table 3) (Guenzi et al., 1998). Syringomycin is synthesized by two nonribosomal peptide (NRP) (SyrB1 and $S y r E)$ and three modifying protein systems (SyrB2, SyrC and $\operatorname{Syr} P$ ) (Roongsawang et al., 2011). Syringomycin displays inhibitory activities against a broad spectrum of fungi, particularly yeasts (Sorensen et al. 1996; Lavermicocca et al. 1997). Syringomycin acts on membranes of the target fungus by forming voltage-dependent and nonselective ion channels (Takemoto et al., 2003). 


\subsection{Viscosin family}

Viscosin was first isolated from a Pseudomonas spp. in 1951. The CLP consists of 9 amino acid cyclic oligopeptides linked to a 3-hydroxydecanoic acid (Figure 5a and Table 3). Viscosin is synthesized by NRP systems that are encoded by three large ORFs, termed viscA, $v i s c B$ and visc $C$. Viscosin's mode of action is to induce surfactant activity by reducing the surface tension of water (Roongsawang et al., 2011). There are many variants of the viscosin family such as massetolide $(\mathrm{C}, \mathrm{G}, \mathrm{A}, \mathrm{H}, \mathrm{L}, \mathrm{B}, \mathrm{F}$ and $\mathrm{D})$, white line inducing principle, viscosin, pseudophomin (A and B), and viscosinamine (Table 3) (Roongsawang et al., 2011). 
Table 3. Primary structure of lipopeptide families and representative variants produced by Pseudomonas spp. Adapted from Roongsawang et al. (2011).

\begin{tabular}{|c|c|}
\hline Group/Name & Structure \\
\hline \multicolumn{2}{|l|}{ Viscosin ${ }^{A}$} \\
\hline Viscosin & FA- $\beta$-OH-L-Leu-D-Glu-D- $\alpha$ Thr-D-Val-L-Leu-D-Ser-L-Leu-D-Ser-L-Ile \\
\hline Viscosinamide & FA- $\beta$-OH-L-Leu-D-Gin-D- $\alpha$ Thr-D-Val-L-Leu-D-Ser-L-Leu-D-Ser-L-Ile \\
\hline Massetolide A & FA- $\beta$-OH-L-Leu-D-Glu-D- $\alpha$ Thr-D- $a$ lle-L-Leu-D-Ser-L-Leu-D-Ser-L-Ile \\
\hline Pseudophomin A & FA- $\beta$-OH-L-Leu-D-Glu-D- $a$ Thr-D- Ile-D-Leu-D-Ser-L-Leu-D-Ser-L-Ile \\
\hline Pseudodesmin A & FA- $\beta$-OH-L-Leu-D-Gln-D- $\alpha$ Thr-D-Val-D-Leu-D-Ser-L-Leu-D-Ser-L-Ile \\
\hline \multicolumn{2}{|l|}{ Syringomycin $^{\mathrm{B}}$} \\
\hline Syringomycin A & FA- $\beta$-OH-L-Ser-D-Ser-D-Dab-L-Dab-L-Arg-L-Phe-Z-Dhb-L-Asp $p_{(3-O H)}-$ L-Thr ${ }_{(+-C l)}$ \\
\hline Syringostatin A & FA- $\beta-O H-L-S e r-D-D a b-L-D a b-D-H s e-L-O r n-L-a T h r-Z-D h b-L-A s p_{(3-O H)}-L-T_{h} r_{(4-C)}$ \\
\hline Syringotoxin B & FA- $\beta$-OH-L-Ser-D-Dab-L-Gly-D-Hse-L-Orn-L-a Thr-Z-Dhb-L-Asp $(3-O H)^{-L-T h r}(4-C)$ \\
\hline Pseudomycin A & FA- $\beta-O H-L-S e r-D-D a b-L-A s p-D-L y s-L-D a b-L-a T h r-Z-D h b-L-A s p_{(3-O H)}-L-T_{14} r_{(4-C)}$ \\
\hline Cormycin A & FA- $\beta$-OH-L-Ser-D-Orn-L-Asn-D-Hse-L-His-L-aThr-Z-Dhb-L-Asp (3-OH) -L-Thr ${ }_{(4-C)}$ \\
\hline \multicolumn{2}{|l|}{ Amphisin ${ }^{\wedge}$} \\
\hline Arthrofactin & FA- $\beta$-OH-D-Leu-D-Asp-D- $a$ Thr-D-Leu-D-Leu-D-Ser-L-Leu-D-Ser-L-Ile-L-Ile-L-Asp \\
\hline Amphisin & FA- $\beta$-OH-D-Leu-D-Asp-D- $a$ Thr-D-Leu-D-Leu-D-Ser-L-Leu-D-Gln-L-Leu-L-Ile-L-Asp \\
\hline Lokisin & FA- $\beta$-OH-D-Leu-D-Asp-D- $a$ Thr-D-Leu-D-Leu-D-Ser-L-Leu-D-Ser-L-Leu-L-Ile-L-Asp \\
\hline Pholipeptin & FA- $\beta$-OH-D-Leu-L-Asp-L- Thr-D-Leu-D-Leu-D-Ser-D-Leu-D-Ser-D-Leu-L-Ile-D-Asp \\
\hline Tensin & FA- $\beta$-OH-D-Leu-D-Asp-D- $a$ Thr-D-Leu-D-Leu-D-Ser-L-Leu-D-Gln-L-Leu-L-Ile-L-Glu \\
\hline \multicolumn{2}{|l|}{ Putisolvin ${ }^{\mathrm{C}}$} \\
\hline Putisolvin I & $\mathrm{CH}_{3}(\mathrm{CH})_{4} \mathrm{CO}$-D-Leu-D-Glu-D-Leu-D-Ile-D-Gin-D-Ser-D-Val-D-lle-D-Ser-L-Leu-L-Val-X-Ser \\
\hline Putisolvin II & $\mathrm{CH}_{3}(\mathrm{CH})_{4} \mathrm{CO}$-D-Leu-D-Glu-D-Leu-D-Ile-D-Gln-D-Ser-D-Val-D-Ile-D-Ser-L-Leu-L-Xle-X-Ser \\
\hline
\end{tabular}

A the hydroxyl group of aThr or Thr form an ester bond with the carboxyl group of the C-terminal amino acid

B the hydroxyl group of L-Ser1 form an ester bond with the carboxyl group of the C-terminal amino acid

${ }^{\mathrm{C}}$ the hydroxyl group of D-Ser9 form an ester bond with the carboxyl group of the C-terminal amino acid 
(a)

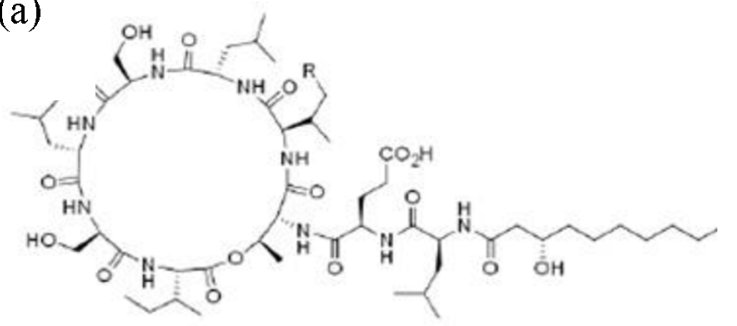

(c)

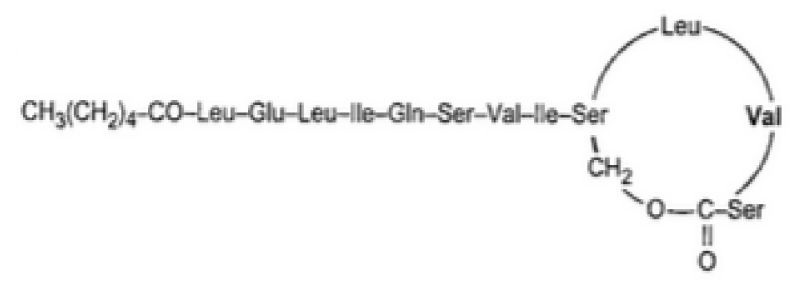

(b)

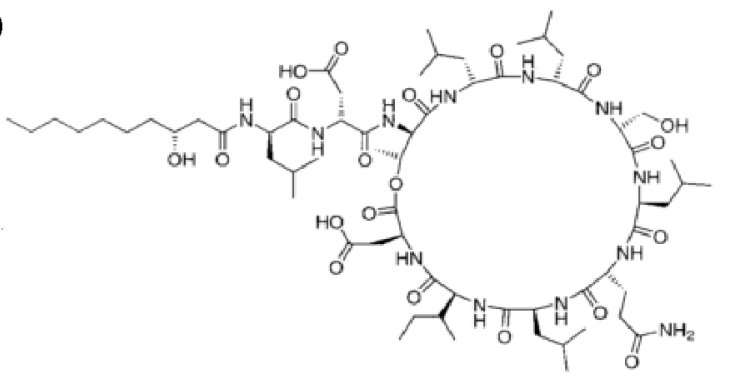

(d)

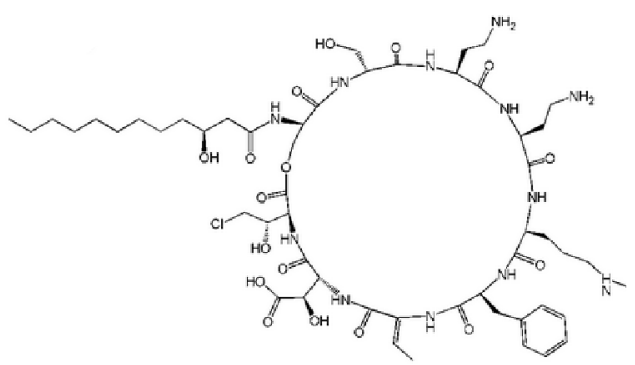

Figure 5: Representative structures of cyclic lipopeptides families produced by Pseudomonas spp. (a) viscosin (Gross and Loper, 2009), (b) amphisin (Sorensen et al., 2001), (c) putisolvin (Kuiper et al., 2003), and (d) syringomycin (Galonic et al., 2006). 


\subsection{Hypotheses and objectives}

Most of the studies on biological control indicated the promise of strains of antagonists to decrease disease incidence or severity. However, the lack of information on secondary metabolites, such as antimicrobials, produced by microbial antagonists has hampered the development of biocontrol agents with consistent disease control.

Bacterial genomes produce many different of bioactive compounds. In Bacillus spp., 4$5 \%$ of their genomes are devoted towards producing more than two dozen antimicrobial compounds (Stein, 2005). In Pseudomonas spp., approximately 6\% (Gross and Loper, 2009) of their genomes are devoted to produce antimicrobial compounds such as phenazine, siderophores, and HCN (Haas and Defago, 2005). Although are large proportion of these bacterial genomes are devoted to antimicrobial production, little is known of the different antimicrobials produced by different antagonistic species, as well as by different isolates or strains with the same species.

Currently, the major challenge in plant pathology is to successfully introduce biological control agents as disease strategies. Additional knowledge of the antimicrobial compounds involved in the inhibition of plant pathogens will undoubtable help in the selection of the most promising antagonists for successful biological control.

\subsubsection{Hypotheses}

(I) Bacteria isolated from suppressive soils, composts, and compost teas will inhibit the growth of plant pathogens.

(II) Compounds isolated from these bacteria will inhibit mycelial growth and spore germination of plant pathogens. 
(III) Conidia will be more susceptible than mycelia to bioactive compounds from Bacillus, Bacillus-related, and Pseudomonas spp.

(IV) Compounds from bacterial extracts contain different families of known antimicrobial lipopeptides.

\subsubsection{Objectives}

The objectives of this study were (I) to investigate the potential antimicrobial activity in various bacteria isolated from suppressive soils, disease suppressive composts, and compost teas, (II) to assay lipopeptide fractions from selected bacteria against mycelial growth and spore germination of plant pathogens, and (III) to detect the presence of various known antimicrobial lipopeptides in the extracts from Bacillus, Bacillus-related, and Pseudomonas spp. 


\section{Chapter 2: Materials and methods}

\subsection{Microbial material}

\subsubsection{Bacteria}

The bacteria Bacillus subtilis isolates B9-1, B9-5, B9-7, B9-8, B9-9A, and B9-14, Paenibacillus favisporus isolate B9-4, Pseudomonas gessardii isolate B9-3, and Bacillus megaterium isolate B9-9B were isolated from a disease suppressive compost prepared with bovine manure and peat moss. Pseudomonas moraviensis isolates F9-2 and F9-11, Pseudomonas arsenicoxydans isolate F9-7, Pseudomonas koreensis isolate F9-9, Pseudomonas proteolytica isolate F9-10, Pseudomonas libanensis isolate F9-13, and B. subtilis isolates F9-2, F9-8, and F912 were isolated from a disease suppressive compost composed of forestry residue and peat moss. Arthrobacter humicola isolates M9-1A, M9-2 and M9-8, B. megaterium isolate M9-1B, B. subtilis isolates M9-3, M9-4, M9-7, M9-9 and M9-14, P. gessardii isolate M9-16, Arthrobacter psychrophenolicus isolate M9-17, Brevibacillus borstelensis isolate M9-18, Rummeliibacillus pycnus isolate M9-19 and Bacillus badius isolate M9-20 were isolated from a disease suppressive compost prepared from marine residue and peat moss. All composts were produced by Berger Peat Moss (Saint-Modeste, QC) (Figure 6).

Bacillus subtilis isolate CU12 (Wise et al. 2012) and Bacillus licheniformis isolate PSA1 were isolated from disease suppressive soils in Ottawa, ON (Figure 6).

Aminobacter aminovorans isolate IB-2, B. subtilis isolates IB-16 and IC-10, Brevibacterium iodinum isolates IB-48 and IC-23, and Advenella kashmirensis isolate IC-6 were isolated from a compost tea prepared from sheep manure compost (Koné et al., 2010; Dionne et al., 2012) (Figure 6). 
All bacteria were stored in glycerol stocks at $-80^{\circ} \mathrm{C}$ and maintained on tryptic soy agar (TSA, Becton Dickinson, Sparks, MD).

\subsubsection{Fungi and oomycetes}

The plant pathogenic fungi A. solani, B. cinerea, F. sambucinum, R. stolonifer, and $V$. dahliae were obtained from the Laboratoire de diagnostic en phytoprotection (MAPAQ, Québec, QC). The plant pathogenic oomycete $P$. sulcatum was isolated from an infected carrot root and is available at the Canadian Collection of Fungal Cultures (Agriculture and Agri-Food

Canada, Ottawa, ON). The pathogens were stored as freeze-dried stocks and maintained on potato dextrose agar (PDA, Becton Dickinson). 


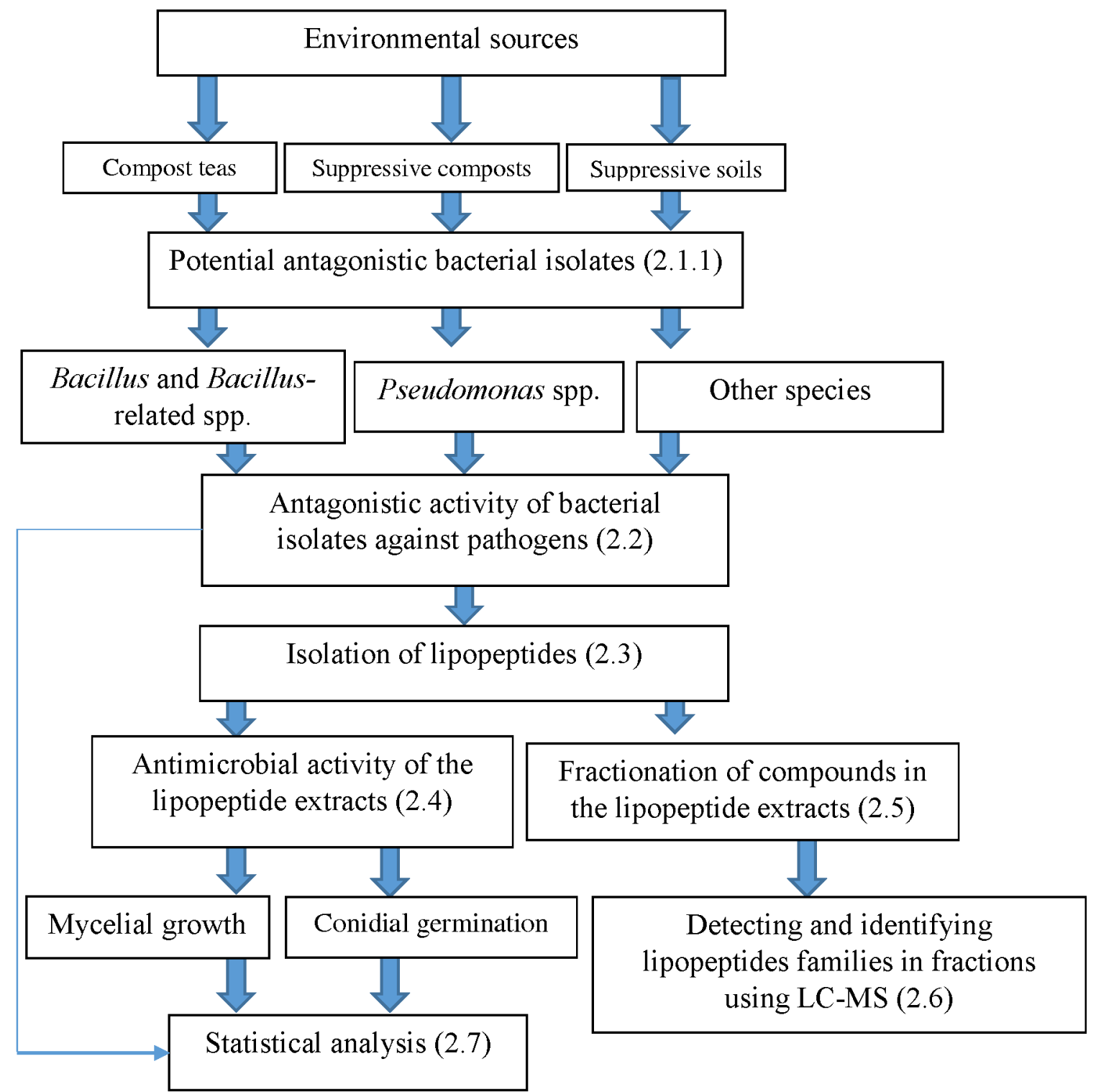

Figure 6. Flow chart showing the experimental samples and methodology for determining antagonistic effects of bacterial isolates and the presence of lipopeptide compounds. 


\subsection{Antagonistic activity of bacterial isolates against pathogens}

The six pathogens were confronted with the isolated bacteria to determine their antagonistic activity. The 40 bacterial isolates were individually inoculated at the four cardinal points on PDA by streaking 1-cm line of each bacterium at a distance of $2 \mathrm{~cm}$ (for A. solani), $3.5 \mathrm{~cm}$ (for B. cinerea, F. sambucinum, P. sulcatum and $R$. stolonifer), and $1 \mathrm{~cm}$ (for $V$. dahliae) from the center of the dish. A 5-mm diameter agar plug containing actively growing mycelium was placed in the center of each Petri dish. Control dishes were inoculated with the pathogens

without bacterial streaks. Petri dishes were incubated for 5, 4, 8, 6, 2, and 10 days for A. solani, B. cinerea, F. sambucinum, $P$. sulcatum, $R$. stolonifer and $V$. dahliae, respectively, at $23^{\circ} \mathrm{C}$ in the dark. Following the incubation period, growth was measured and expressed as the average of two perpendicular diameters of the thallus. The experiments were conducted according to a completely randomized design with three replicates (Figure 6).

\subsection{Extraction of lipopeptides}

\subsubsection{Preparation of medium optimized for lipopeptide production (MOLP)}

Individual bacterial isolates were grown in medium optimized for lipopeptide production (MOLP) as described by Akpa et al. (2001). Briefly, MOLP contains 20 g sucrose, 30 g peptone, $7 \mathrm{~g}$ yeast extract, $1.9 \mathrm{~g} \mathrm{KH}_{2} \mathrm{PO}_{4}, 0.45 \mathrm{~g} \mathrm{MgSO}_{4}, 9 \mathrm{ml}$ Trace Element Solution (TES), and $9 \mathrm{ml}$ of a citric acid solution $\left(10 \mathrm{~g} / \mathrm{L} \mathrm{ddH_{2 } \mathrm { O }}\right)$. TES was prepared by adding $\mathrm{CuSO}_{4}(0.001 \mathrm{~g}), \mathrm{FeCl}_{3}$ (0.005 g), $\mathrm{Na}_{2} \mathrm{MoO}_{4}(0.004 \mathrm{~g}), \mathrm{KI}(0.002 \mathrm{~g}), \mathrm{ZnSO}_{4}(0.014 \mathrm{~g}), \mathrm{H}_{3} \mathrm{BO}_{3}(0.01 \mathrm{~g}), \mathrm{MnSO}_{4}(0.0036$ g) to $1 \mathrm{~L}$ of sterile ultra-pure water. MOLP components were added to $982 \mathrm{ml}$ of $\mathrm{ddH}_{2} \mathrm{O}$ and sterilized. 


\subsubsection{Bacterial growth and recovery of cell-less culture medium}

Selected isolates representing Pseudomonas, Bacillus and Bacillus-related spp. were individually inoculated into three $250-\mathrm{ml}$ Erlenmeyer flasks containing $50 \mathrm{ml}$ of sterilized MOLP. Inoculated samples were incubated at $30^{\circ} \mathrm{C}$ and $130 \mathrm{rpm}$ for $72 \mathrm{~h}$ (for isolates B9-1, B9-3, B9-4, B9-5, B9-7, B9-8, B9-9A, B9-9B, B9-14, CU12, IB16, IC10, M9-3, M9-4, M9-7, M9-9, M9-14, M9-16, M9-18, M9-19, and M9-20) or 96 h (for isolates F9-2, F9-6, F9-7, F9-8, F9-9, F9-10, F9-11, F9-12, F9-13 and PSA1). Incubated isolates were transferred to 50-ml sterile plastic tubes and centrifuged at $4,300 \mathrm{rpm}$ for $30 \mathrm{~min}$ at $4{ }^{\circ} \mathrm{C}$. The supernatant was then filtered through sterile, $500-\mathrm{ml} 0.45 \mu \mathrm{m}$ polyether sulfone (PES) filter units (Celltreat, Mandel Scientific, Guelph, ON). The cell-free filtrates were stored at $4^{\circ} \mathrm{C}$ until use (Figure 6).

\subsubsection{Lipopeptide precipitation}

The lipopeptides in the filtrates were precipitated using $30 \% \mathrm{w} / \mathrm{v}$ ammonium sulfate $\left[\left(\mathrm{NH}_{4}\right)_{2} \mathrm{SO}_{4}\right]$ by adding $15 \mathrm{~g}$ of $\left(\mathrm{NH}_{4}\right)_{2} \mathrm{SO}_{4}$ to each tube. The tubes were then shaken and incubated at $4^{\circ} \mathrm{C}$ overnight. Samples were centrifuged for $60 \mathrm{~min}$ at $4,300 \mathrm{rpm}$ and $4^{\circ} \mathrm{C}$ to recover lipopeptides. Supernatants were discarded and the precipitated lipopeptides were suspended in $5 \mathrm{ml}$ of $10 \mathrm{mM}$ phosphate buffer $(\mathrm{pH}=6.1)$ (Figure 6).

\subsection{Antimicrobial activity of the lipopeptide extracts}

Fourteen bacterial isolates were chosen to test the antimicrobial activity of lipopeptide extracts in the inhibition of mycelial growth and conidial germination. Three categories representing isolates from different inhibition class (from section 2.2) were chosen: class 1 
(containing B. subtilis B9-5, B9-14, IC10, CU12, M9-9, P. proteolytica F9-10 and P. koreensis F9-11) reduced the growth of all pathogens; class 2 (containing B. subtilis M9-7, F9-8, F9-2 and F9-12, P. koreensis F9-9 and P. arsenicoxydans F9-7) reduced the growth of some, but not all of the pathogens; and class 3 (containing B. badius M9-20) did not reduce the growth of any of the tested pathogens. Tests were performed to assess the extracts against different morphological structures (mycelium and/or conidia) of the pathogens.

\subsubsection{Effect of crude lipopeptide extracts on mycelia growth}

The antifungal activities of lipopeptide extracts were tested using a disc diffusion assay with A. solani, B. cinerea, F. sambucinum, $P$. sulcatum, R. stolonifer and $V$. dahliae. Briefly, 25 $\mu \mathrm{L}$ of each crude extract $(10 \times$ concentrated $)$ was placed on sterile filter paper disks $(0.5 \mathrm{~cm}$ diameter) and left to dry for $1 \mathrm{~h}$. Sterile ultra-pure water was used as a control. Petri dishes containing PDA were inoculated with a 5-mm diameter agar plug containing actively growing mycelium. The dried paper disks containing lipopeptide extracts or controls were placed at a distance of $2 \mathrm{~cm}$ (for A. solani), $3.5 \mathrm{~cm}$ (for B. cinerea, F. sambucinum, P. sulcatum and $R$. stolonifer), and $1 \mathrm{~cm}$ (for $V$. dahliae) from the agar plugs. All Petri dishes were incubated at $23^{\circ} \mathrm{C}$ in the dark for $6,3,5,6,2$ and 12 days for A. solani, B. cinerea, $F$. sambucinum, $P$. sulcatum, R. stolonifer and $V$. dahliae, respectively. Mycelial growth was measured as the radius of the thallus facing the paper disc containing samples or controls. The experiments were conducted according to a completely randomized design with three replicates (Figure 6). 


\subsubsection{Effect of crude lipopeptide extracts on spore germination}

Antifungal activities were tested using a spore germination assay with A. solani, B. cinerea, $F$. sambucinum, $R$. stolonifer, and $V$. dahliae. Each sample was concentrated 10 times and $25 \mu \mathrm{L}$ was placed in a sterile $1.5 \mathrm{~mL}$ conical snap-cap tube (Eppendorf tube) evaporated and re-suspended in $90 \mu \mathrm{L}$ of sterile water. $90 \mu \mathrm{L}$ of sterile water without sample served as the control. $10-\mu \mathrm{L}$ spore suspensions $\left(5 \times 10^{5}\right.$ spores $/ \mathrm{mL}$ in sterile water) of $A$. solani, B. cinerea, $F$. sambucinum, $R$. stolonifer and $V$. dahliae were individually added to each treatment. The treated spores were incubated at $23^{\circ} \mathrm{C}$ for $30 \mathrm{~min}$ and $100 \mu \mathrm{L}$ of the suspension was spread on water agar (containing $15 \mathrm{~g} / \mathrm{L}$ agar). The Petri dishes were incubated for $24 \mathrm{~h}$ (R. stolonifer), 28 h $(B$. cinerea and $F$. sambucinum $)$ or $48 \mathrm{~h}(V$. dahliae and $A$. solani $)$ at $23^{\circ} \mathrm{C}$ in the dark. Following the incubation period, Petri dishes were observed under visible light using an inverted microscope. Spores were considered germinated when the length of the germ tube equaled at least the length of the spore. The percentage of germinated cells was calculated as follows: percent germination $=$ germinated spores/total spores $\times 100$. The experiment was performed according to a completely randomized design with three replicates (Figure 6).

\subsection{Fractionation of lipopeptide extracts}

Reverse-phase sterile $5 \mathrm{~mL} \mathrm{C}_{18}$ cartridges (Bond Elut, Varian, Mississauga, ON) were used for fractionation. The extracts in phosphate buffer were concentrated 5 times by bringing samples to dryness using a rotary evaporator at $150 \mathrm{rpm}$ and $35-40^{\circ} \mathrm{C}$ and resuspended in $1 \mathrm{~mL}$ of phosphate buffer (pH 6.4). The column was conditioned twice with $5 \mathrm{~mL}$ of ultra-pure water. Samples were placed on the column and the flow through was collected. The column was sequentially eluted with $5 \mathrm{~mL}$ of various ratios of methanol:water as follows: 0:100, 20:80, 
50:50, 80:20, and 100:0. Five fractions (F1-F5) obtained were brought to dryness using a rotary evaporator at $150 \mathrm{rpm}$ and $35-40^{\circ} \mathrm{C}$. Samples were suspended in $200 \mu \mathrm{l}$ of $100 \%$ methanol, passed through syringe filters $(0.45 \mu \mathrm{m})$ and transferred to auto-sampler vials containing $250-\mu 1$ inserts (Figure 6).

To characterize the presence of lipopeptides produced by the antagonistic bacterial isolates, preliminary study was done to screen all the fractions from the various ratios of methanol:water as follows: 0:100, 20:80, 50:50, 80:20, and 100:0. Previous work on these lipopeptide extracts with this methodology showed that the $80 \%$ and $100 \%$ methanol fractions (F4 and F5) contained the lipopeptides. Therefore, these two fractions were the samples analyzed by LCMS.

\subsection{Characterization of lipopeptides in bacterial extracts}

Liquid chromatography-electrospray ionization-mass spectrometry (LC-ESI-MS) was performed using a Waters 2795 separations module and MicroMass Quatro Ultima triple quadrupole mass spectrometer. Samples were separated by a Phenomenex Kinetix $C_{18}(100 \times$ $4.6 \mathrm{~mm}, 2.6 \mu \mathrm{m}, 100 \AA$ ) column (Torrance, California) using a mobile phase consisting of acetonitrile-water $\left(\mathrm{ACN}-\mathrm{H}_{2} \mathrm{O}\right)$ with formic acid (FA) $[0.1 \%$, (v/v)]. The solvent gradient was

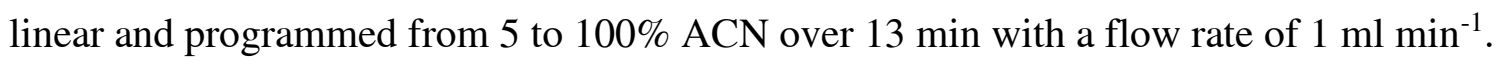

Positive ESI conditions included: capillary voltage $3.5 \mathrm{kV}$, cone voltage $20 \mathrm{~V}$, source temperature $80^{\circ} \mathrm{C}$, desolvation temperature $180^{\circ} \mathrm{C}$, cone gas flow $\left(\mathrm{N}_{2}\right) 90 \mathrm{l} / \mathrm{h}$, desolvation gas flow $\left(\mathrm{N}_{2}\right) 540 \mathrm{l} / \mathrm{h}$, and multiplier voltage of $650 \mathrm{~V}$. The mass range examined was $\mathrm{m} / z$ 900-1600. Lipopeptides were identified by comparison with authentic standards and MS data available in the literature. 
Comparative analysis of mass spectra of the two methanolic fractions (80\% and 100\%), revealed quantitative variability of $\mathrm{m} / \mathrm{z}$ ions masses and series of homologs corresponding to lipopeptides families belonging Bacillus and Pseudomonas spp. Identification of lipopeptides was further confirmed by comparing to retention time to specific region of spectra that belongs to each family of the lipopeptides and by comparing these to authentic standards (Figure 6).

\subsection{Statistical analysis}

For the antagonistic confrontation trials, the disc diffusion assay, and spore germination assay, analysis of variance (ANOVA) was performed and, when significant $(\mathrm{P}<0.05)$, means were compared using Fisher's protected least significant difference (LSD) test $(\alpha$ level $=0.05)$ (Figure 6). 


\section{Chapter 3: Results}

\subsection{Antagonistic activity of bacterial isolates against fungi}

Antifungal activities of forty bacterial isolates were investigated by testing their potential to inhibit the mycelial growth of $A$. solani, B. cinerea, F. sambucinum, P. sulcatum, R. stolonifer and $V$. dahliae in vitro (Table 4). The following sixteen isolates were able to reduce the growth of all six tested pathogens (Table 4): P. proteolytica F9-10 (61\% inhibition), P. libanensis F9$13(56 \%)$, B. subtilis IC10 and IB2 (39\%), CU12 and B9-5 (37\%), B9-14 and M9-14 (36\%), B9-7 and B9-9A (35\%), M9-4 and M9-9 (33\%), and M9-3 (29\%), and P. moraviensis F9-6 (37\%), A. kashmirensis IC6 (34\%) and F9-11 (36\%).

In addition, nine of the bacterial isolates inhibited five of the six pathogens. Specifically, B. subtilis B9-1 (39 \% average inhibition), F9-12 (37\%), F9-8 and IB16 (36\%), F9-2 and B9-8 (34\%) reduced the growth of all pathogens with the exception of R. stolonifer. Also, R. pycnus M9-19 (29\%) reduced the growth of all pathogens with the exception of P. sulcatum. P. koreensis F9-9 (31\% inhibition) reduced the growth of all pathogens with the exception of $F$. sambucinum, and B. subtilis M9-7 (36\%) reduced the growth of all pathogens with the exception of B. cinerea (Table 4).

Furthermore, five bacterial isolates inhibited four of the six pathogens. B. subtilis M9-2 (42\% inhibition) reduced the growth of all pathogens with the exception of $F$. sambucinum and R. stolonifer. Additionally, P. arsenicoxydans F9-7 (28\%) reduced the growth of all pathogens with the exception of $B$. cinerea and $R$. stolonifer. P. gessardii B9-3 (27\%) reduced the growth of all pathogens with the exception of P. sulcatum and V. dahliae. B. borstelensis M9-18 (22\%) reduced the growth of all pathogens with the exception of $P$. sulcatum and $R$. stolonifer. Finally, 
A. psychrophenolicus M9-17 (16\%) reduced the growth of all pathogens with the exception of A. solani and P. sulcatum (Table 4).

Moreover, two bacterial isolates inhibited three of the six pathogens. B. megaterium B99B (30\% inhibition) reduced the growth of A. solani, B. cinerea and F. sambucinum. P. gessardii M9-16 (30\%) reduced the growth of A. solani, F. sambucinum and V. dahliae (Table 4).

Three other bacterial isolates inhibited two of the six pathogens. Arthrobacter humicola M9-1A (26\% inhibition) reduced the growth of $F$. sambucinum and $V$. dahliae. B. iodinum IB48 (19\%) reduced the growth $A$. solani and F. sambucinum. Finally, B. subtilis M9-8 (24\%) reduced the growth of B. cinerea and F. sambucinum (Table 4).

Three additional bacterial isolates inhibited only one of the six pathogens. B. megaterium M9-1B only inhibited the growth of $P$. sulcatum (25\%), B. iodinum IC 23 only reduced the mycelial growth of $R$. stolonifer (13\%), and B. licheniformis PSA1 only inhibited the growth of A. solani (25\%) (Table 4).

Finally, two bacterial isolates (P. favisporus B9-4 and B. badius M9-20) showed no significant reduction on the mycelial growth of any of the six pathogens (Table 4).

With regard to the inhibition of $A$. solani, $P$. proteolytica F9-10, B. subtilis IB-2 and $P$. libanensis F9-13 showed the highest inhibitory effect (68\% inhibition) whereas P. favisporus B9-4, B. badius M9-20, A. humicola M9-1A, B. megaterium M9-1B, B. iodinum IC-23, B. subtilis M9-8 and A. psychrophenolicus M9-17, showed no significant inhibitory effect on its mycelial growth (Table 4).

In B. cinerea trails, $P$. libanensis F9-13, A. humicola M9-2 and P. koreensis F9-9 showed the highest inhibition (49\%) of mycelial growth whereas P. favisporus B9-4, B. badius M9-20, A. humicola M9-1A, B. megaterium M9-1B, B. iodinum IC-23, P. gessardii M9-17 and B9-3, 
B. subtilis M9-7, B. iodinum IB48 and B. licheniformis PSA1 had no significant inhibitory effect on its mycelial growth (Table 4).

Pseudomonas proteolytica F9-10 showed the highest inhibitory effect on the mycelial growth of $F$. sambucinum (58\%) whereas $P$. favisporus B9-4, B. badius M9-20, B. megaterium M9-1B, B. iodinum IC-23, P. koreensis F9-9, A. humicola M9-2, and B. licheniformis PSA1 had no significant inhibitory effect on its mycelial growth (Table 4).

Two isolates, $P$. proteolytica F9-10 and P. libanensis F9-13, decreased the mycelial growth of $P$. sulcatum by 68\%. Conversely, P. favisporus B9-4, B. megaterium B9-9B, P. arsenicoxydans F9-7, B. iodinum IB48 and IC23, B. badius M9-20, A. humicola M9-1A, M9-8, P. gessardii M9-16, A. psychrophenolicus M9-17, B. borstelensis M9-18, R. pycnus M9-19 and B. licheniformis PSA1 had no significant inhibitory effect on its mycelial growth (Table 4).

For R. stolonifer, P. proteolytica F9-10, P. libanensis F9-13, P. moraviensis F9-11 and R. pycnus M9-19 showed the highest reduced the mycelial growth (50\%) whereas P. favisporus B9-4, B. badius M9-20, A. humicola M9-2, M9-1A and M9-8, B. megaterium M9-1B, $P$. gessardii M9-16 and B9-3, B. subtilis B9-1, IB16, F9-2, B9-8, F9-8 and F9-12 B. megaterium B9-9B, B. iodinum IB48, B. borstelensis M9-18 and B. licheniformis PSA1 had no significant inhibitory effect on its mycelial growth (Table 4).

Pseudomonas proteolytica F9-10, P. libanensis F9-13 and P. moraviensis F9-6 showed the highest inhibition of mycelial growth of $V$. dahliae (57\%) whereas P. favisporus B9-4, B. badius M9-20, A. humicola M9-8, B. megaterium M9-1B, B. megaterium B9-9B, B. iodinum IB48, B. iodinum IC23, P. arsenicoxydans F9-7 and B. licheniformis PSA1 revealed no significant inhibitory effect on its mycelial growth (Table 4). 
In addition to measurement of mycelial growth shown in Table 4, relative inhibitory activity was calculated for the isolates in three groups (Bacillus spp. and Bacillus-related spp., Pseudomonas spp., and other tested species) (Figure 7). The Pseudomonas spp. group showed the greatest relative efficiency in inhibiting combined pathogens. Bacillus and Bacillus-related spp. showed less total relative inhibition in mycelial growth. Finally, isolates from species other than Bacillus and Bacillus-related or Pseudomonas spp. showed the least total relative inhibition of the pathogens (Figure 7). 
Table 4. In vitro inhibitory activities of forty bacterial isolates from composts, compost tea, and soil against six pathogens: Alternaria solani, Botrytis cinerea, Fusarium sambucinum, Pythium sulcatum, Rhizopus stolonifer and Verticillium dahliae.

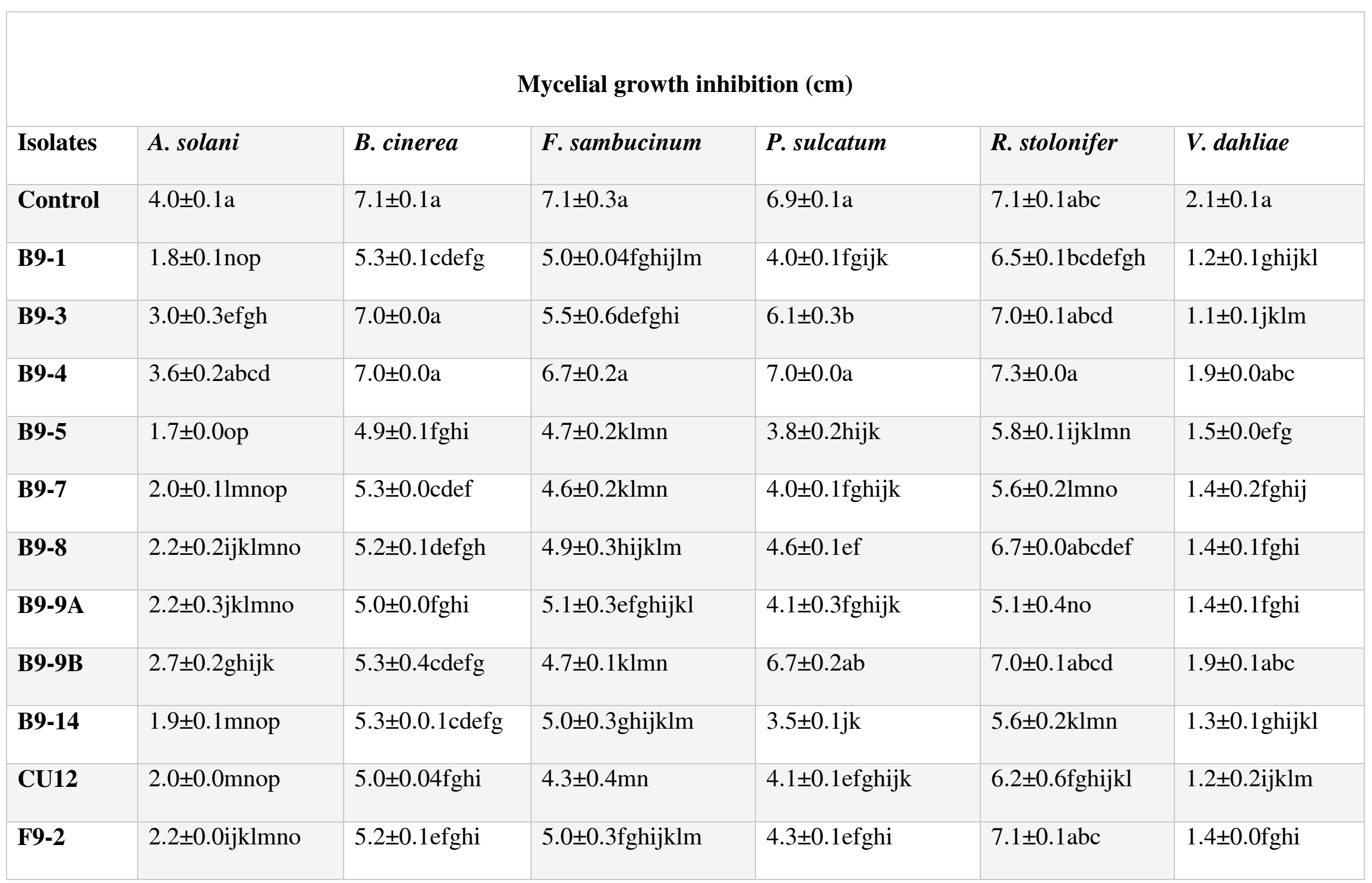




\section{Mycelial growth inhibition (cm)}

\begin{tabular}{|c|c|c|c|c|c|c|}
\hline Isolates & A. solani & B. cinerea & F. sambucinum & P. sulcatum & R. stolonifer & V. dahliae \\
\hline F9-6 & $3.0 \pm 0.0 \mathrm{defgh}$ & $4.30 \pm 0.2 \mathrm{k}$ & $4.8 \pm 0.2 \mathrm{ijklm}$ & $4.6 \pm 0.2 \mathrm{ef}$ & $4.9 \pm 0.10$ & $0.92 \pm 0.0 \mathrm{mn}$ \\
\hline F9-7 & $3.3 \pm 0.0 \mathrm{bcdef}$ & $4.3 \pm 0.1 \mathrm{k}$ & $4.7 \pm 0.1$ efghijkl & $7.0 \pm 0.0 \mathrm{a}$ & $5.2 \pm 0.0 \mathrm{mno}$ & $2.0 \pm 0.0 \mathrm{ab}$ \\
\hline F9-8 & $2.7 \pm 0.7$ ghij & $4.9 \pm 0.0$ ghij & $4.7 \pm 0.3 \mathrm{jklm}$ & $3.8 \pm 0.4 \mathrm{ghijk}$ & $6.5 \pm 0.4 \mathrm{bcdefg}$ & $1.3 \pm 0.0 \mathrm{ghijkl}$ \\
\hline F9-9 & $2.8 \pm 0.1$ fghi & $3.6 \pm 0.7 \mathrm{~m}$ & $6.3 \pm 0.5 \mathrm{abcd}$ & $5.3 \pm 0.1 \mathrm{~cd}$ & $4.9 \pm 0.10$ & $1.3 \pm 0.2 \mathrm{ghijkl}$ \\
\hline F9-10 & $0.9 \pm 0.2 q$ & $4.1 \pm 0.0 \mathrm{kl}$ & $2.9 \pm 0.0 \mathrm{o}$ & $2.0 \pm 0.11$ & $3.7 \pm 0.2 p$ & $0.70 \pm 0.0 \mathrm{n}$ \\
\hline F9-11 & 2.6 \pm 0.0 ghijkl & $4.5 \pm 0.1 \mathrm{jk}$ & $5.5 \pm 0.1$ efghij & $4.5 \pm 0.4 \mathrm{efgh}$ & $3.9 \pm 0.3 p$ & $1.2 \pm 0.0 \mathrm{hijkl}$ \\
\hline F9-12 & $1.8 \pm 0.1$ nop & $5.2 \pm 0.2 \mathrm{defgh}$ & $4.6 \pm 0.1 \mathrm{klmn}$ & $4.5 \pm 0.0 \mathrm{efg}$ & $7.0 \pm 0.1 \mathrm{abc}$ & $1.3 \pm 0.0$ ghijkl \\
\hline F9-13 & $1.5 \pm 0.1 \mathrm{pq}$ & $3.6 \pm 0.3 \mathrm{~m}$ & $3.9 \pm 0.3 n$ & $2.4 \pm 0.31$ & $3.5 \pm 0.3 p$ & $0.78 \pm 0.0 \mathrm{n}$ \\
\hline IB-2 & $1.4 \pm 0.2 \mathrm{pq}$ & $5.0 \pm 0.0$ fghi & $5.0 \pm 0.1$ hijklm & $3.8 \pm 0.1$ ghijk & $5.5 \pm 0.11 \mathrm{mno}$ & $1.3 \pm 0.1$ ghijkl \\
\hline IB-16 & $2.2 \pm 0.11 \mathrm{jklmno}$ & $5.2 \pm 0.0 \mathrm{defgh}$ & $4.7 \pm 0.2 \mathrm{jklmn}$ & $3.9 \pm 0.1$ fghijk & $6.5 \pm 0.2 \mathrm{bcdfgh}$ & $1.5 \pm 0.1 \mathrm{efgh}$ \\
\hline IB-48 & $3.1 \pm 0.1 \mathrm{cdefg}$ & $6.9 \pm 0.1 \mathrm{a}$ & $5.9 \pm 0.1 \mathrm{bcde}$ & $7.0 \pm 0.0 \mathrm{a}$ & $6.8 \pm 0.1 \mathrm{abcdef}$ & $2.0 \pm 0.0 \mathrm{ab}$ \\
\hline IC-6 & $2.5 \pm 0.2 \mathrm{hijklm}$ & $4.8 \pm 0.1 \mathrm{ij}$ & $4.7 \pm 0.2 \mathrm{jklm}$ & $4.8 \pm 0.4 \mathrm{de}$ & 5.9 \pm 0.6 ghijkl & $1.1 \pm 0.01 \mathrm{~m}$ \\
\hline IC-10 & $1.9 \pm 0.1 \mathrm{mnop}$ & $4.8 \pm 0.1 \mathrm{hij}$ & $4.7 \pm 0.2 \mathrm{jklm}$ & $3.6 \pm 0.2 \mathrm{ijk}$ & $5.9 \pm 0.04 \mathrm{ijklmn}$ & $1.1 \pm 0.1 \mathrm{jklm}$ \\
\hline
\end{tabular}




\section{Mycelial growth inhibition (cm)}

\begin{tabular}{|c|c|c|c|c|c|c|}
\hline Isolates & A. solani & B. cinerea & F. sambucinum & P. sulcatum & R. stolonifer & V. dahliae \\
\hline IC-23 & $3.5 \pm 0.1 \mathrm{abcde}$ & $6.9 \pm 0.0 \mathrm{ab}$ & $6.7 \pm 0.2 \mathrm{a}$ & $7.0 \pm 0.0 \mathrm{a}$ & $6.3 \pm 0.3$ efghijk & $1.9 \pm 0.1 \mathrm{abc}$ \\
\hline M9-1A & $3.4 \pm 0.1 \mathrm{abcde}$ & $7.0 \pm 0.0 \mathrm{a}$ & $5.8 \pm 0.5$ bcdefg & $7.0 \pm 0.1 \mathrm{a}$ & $6.9 \pm 0.2 \mathrm{abcde}$ & $1.4 \pm 0.2 \mathrm{ghijk}$ \\
\hline M9-1B & $3.4 \pm 0.1 \mathrm{abcde}$ & $6.9 \pm 0.1 \mathrm{a}$ & $6.4 \pm 0.4 \mathrm{abc}$ & $6.0 \pm 0.8 b c$ & 7.0 $\pm 0.0 \mathrm{abcd}$ & $2.0 \pm 0.0 \mathrm{ab}$ \\
\hline M9-2 & $2.4 \pm 0.1$ hijklm & $3.4 \pm 0.1 \mathrm{~m}$ & $6.4 \pm 0.1 \mathrm{ab}$ & $3.5 \pm 0.8 \mathrm{jk}$ & $6.4 \pm 0.4$ cdefghi & $1.4 \pm 0.0 \mathrm{efgh}$ \\
\hline M9-3 & $2.3 \pm 0.0 \mathrm{ijklmn}$ & $5.5 \pm 0.1 \mathrm{cde}$ & $4.7 \pm 0.3 \mathrm{klmn}$ & $4.2 \pm 0.3$ efghij & $5.5 \pm 0.11 \mathrm{mno}$ & $1.7 \pm 0.2 \mathrm{cde}$ \\
\hline M9-4 & $2.0 \pm 0.1 \mathrm{mnop}$ & $5.3 \pm 0.1 \mathrm{cdefg}$ & $4.8 \pm 0.3 \mathrm{ijklm}$ & $3.7 \pm 0.1 \mathrm{ijk}$ & $6.3 \pm 0.4$ defghij & $1.5 \pm 0.1 \mathrm{efg}$ \\
\hline M9-7 & $1.8 \pm 0.2 \mathrm{nop}$ & $7.0 \pm 0.0 \mathrm{a}$ & $4.7 \pm 0.1 \mathrm{jklm}$ & 4.1 \pm 0.1 efghijk & $5.9 \pm 0.1$ ghijkl & $1.4 \pm 0.1 \mathrm{ghijk}$ \\
\hline M9-8 & $3.5 \pm 0.1 \mathrm{abcde}$ & $5.2 \pm 0.0 \mathrm{defghi}$ & $5.6 \pm 0.2 \mathrm{cdefgh}$ & $6.9 \pm 0.1 \mathrm{a}$ & $7.0 \pm 0.0 \mathrm{abcd}$ & $1.8 \pm 0.2 \mathrm{abcd}$ \\
\hline M9-9 & $2.1 \pm 0.1 \mathrm{klmno}$ & $5.2 \pm 0.0 \mathrm{defgh}$ & 5.5 \pm 0.0 defghi & $3.4 \pm 0.1 \mathrm{k}$ & $5.8 \pm 0.3 \mathrm{hijklm}$ & $1.4 \pm 0.0$ fghij \\
\hline M9-14 & $2.0 \pm 0.3 \mathrm{mnop}$ & $5.3 \pm 0.1 \mathrm{cdefg}$ & $4.5 \pm 0.41 \mathrm{mn}$ & $3.6 \pm 0.1 \mathrm{ijk}$ & $5.7 \pm 0.1 \mathrm{jklmn}$ & $1.4 \pm 0.1 \mathrm{fghi}$ \\
\hline M9-16 & $3.0 \pm 0.0 \mathrm{efgh}$ & $7.0 \pm 0.0 \mathrm{a}$ & $5.8 \pm 0.7 \mathrm{bcdef}$ & $7.0 \pm 0.3 \mathrm{ab}$ & $6.9 \pm 0.1 \mathrm{abcde}$ & $1.2 \pm 0.1 \mathrm{hijkl}$ \\
\hline M9-17 & $3.7 \pm 0.1 \mathrm{abc}$ & $6.5 \pm 0.2 b$ & $5.1 \pm 0.2$ efghijkl & $6.9 \pm 0.1 \mathrm{a}$ & $6.1 \pm 0.4$ fghijkl & $1.8 \pm 0.1 \mathrm{bcd}$ \\
\hline M9-18 & $3.1 \pm 0.2 \mathrm{cdefg}$ & $5.7 \pm 0.04 c$ & $5.3 \pm 0.2$ efghijk & $7.0 \pm 0.0 \mathrm{a}$ & $6.4 \pm 0.5$ bcdefgh & $1.6 \pm 0.1 \mathrm{def}$ \\
\hline
\end{tabular}




\section{Mycelial growth inhibition (cm)}

\begin{tabular}{|l|l|l|l|l|l|l|}
\hline Isolates & A. solani & B. cinerea & F. sambucinum & P. sulcatum & R. stolonifer & V.dahliae \\
\hline M9-19 & $3.0 \pm 0.6 \mathrm{efgh}$ & $5.6 \pm 0.0 \mathrm{~cd}$ & $4.9 \pm 0.5 \mathrm{hijklm}$ & $6.9 \pm 0.0 \mathrm{a}$ & $3.7 \pm 0.0 \mathrm{p}$ & $1.8 \pm 0.1 \mathrm{bcd}$ \\
\hline M9-20 & $3.9 \pm 0.1 \mathrm{ab}$ & $7.0 \pm 0.0 \mathrm{a}$ & $7.0 \pm 0.0 \mathrm{a}$ & $7.0 \pm 0.0 \mathrm{a}$ & $7.1 \pm 0.1 \mathrm{abc}$ & $2.0 \pm 0.0 \mathrm{ab}$ \\
\hline PSA1 & $3.0 \pm 0.4 \mathrm{efgh}$ & $7.0 \pm 0.1 \mathrm{a}$ & $7.1 \pm 0.1 \mathrm{a}$ & $7.0 \pm 0.1 \mathrm{a}$ & $7.1 \pm 0.1 \mathrm{ab}$ & $2.0 \pm 0.0 \mathrm{ab}$ \\
\hline
\end{tabular}

Values are growth diameter of the pathogen thallus (averages of three replicates \pm SEM).

Within a column, values sharing the same letter are not significantly different according to Fisher's protected LSD test $(\alpha$ level $=0.05)$. 


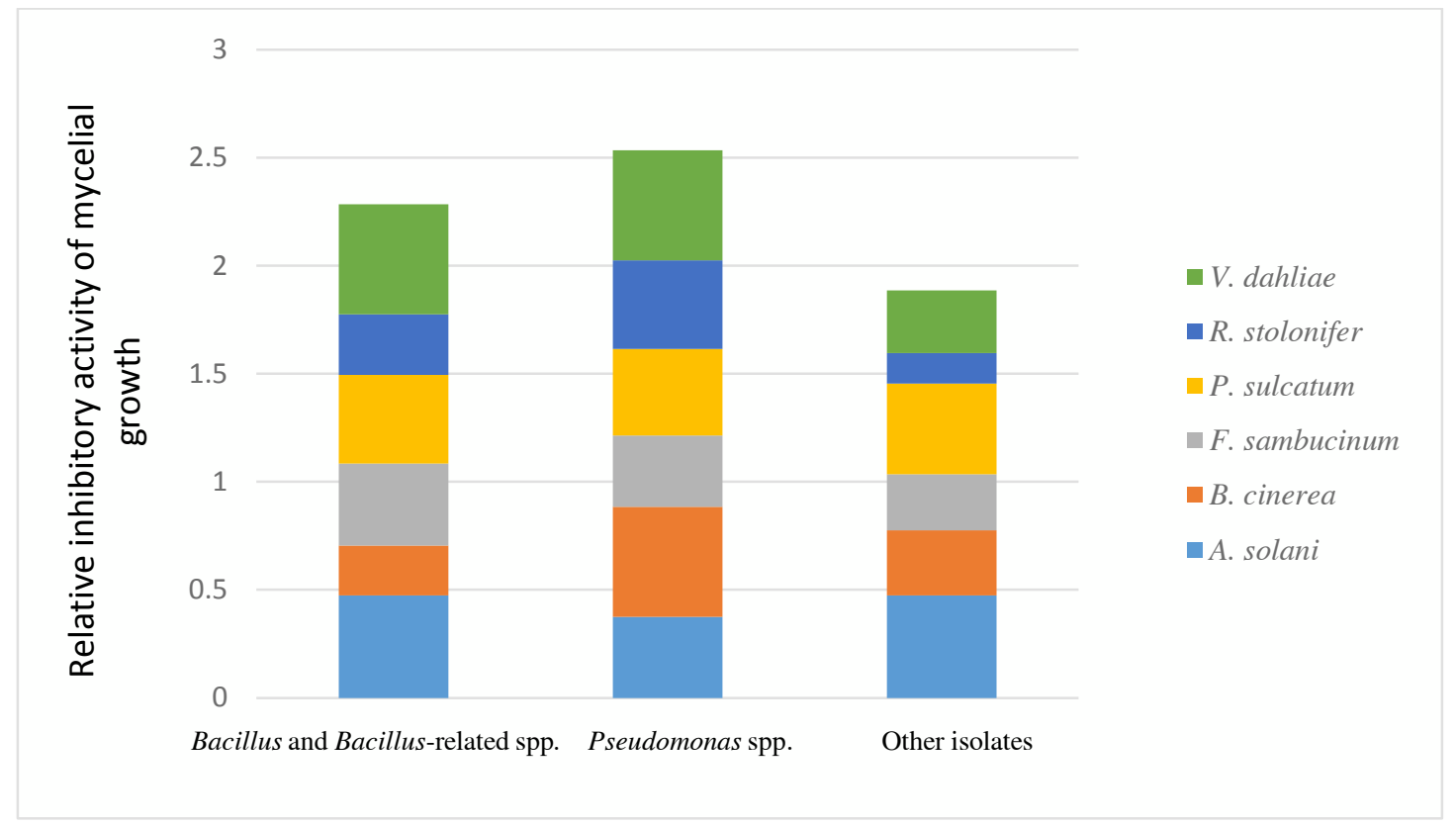

Figure 7. Relative inhibitory activity on pathogen mycelial growth by bacterial isolates from Bacillus and Bacillus-related spp., Pseudomonas spp. and other isolates. Values were calculated from Table 4. Relative inhibitory activity $=$ [(growth of mycelial radius control)(growth of mycelial from the treatment)]/(growth of mycelial radius control).

\subsection{Effect of lipopeptide extracts on mycelial growth}

In order to assess the involvement of lipopeptide compounds in the observed inhibition, extracts from fourteen isolates representing different inhibition groups were used to examine their inhibitory effect on mycelial growth of the pathogens.

Among the tested bacterial isolates, samples from B. subtilis isolates F9-8, M9-7, M9-9, CU12 and B9-5 showed the highest antagonist activity against A. solani, reducing mycelial growth by $29 \%$ (Table 5). A group consisting of B. subtilis IC10 and B9-1, B. badius M9-20, P. arsenicoxydans F9-7, P. proteolytica F9-10 and P. moraviensis F9-11, also reduced the mycelial growth of A. solani. Samples from P. koreensis F9-9 and B. subtilis F9-2 and F9-12, were not significantly inhibitory to A. solani mycelial growth (Table 5). 
Furthermore, samples from B. subtilis M9-9, CU12, IC10, B9-5, and P. koreensis F9-9 showed a significant reduction (10\%) of the mycelial growth of $B$. cinerea (Table 5). The remaining isolates exhibited no inhibitory effect on $B$. cinerea mycelial growth.

Four lipopeptide samples were equally efficient in reducing mycelial growth of $F$. sambucinum. Indeed, B. subtilis CU12, B9-14, and M9-7 and P. koreensis F9-9 caused a 17\% reduction in mycelial growth (Table 5). No other samples showed inhibitory effect against $F$. sambucinum (Table 5).

Ten lipopeptide samples showed significant reduction in the mycelial growth of $P$. sulcatum when compared to the control group (Table 5). The highest inhibition found for samples from $P$. koreensis F9-9 and B. subtilis M9-9, CU12, and IC10 (16\% inhibition). $P$. proteolytica F9-10, B. subtilis B9-5, B9-14 and M9-7, B. badius M9-20, P. arsenicoxydans F97 also demonstrated significant inhibition when compared to the control. Conversely, samples from $B$. subtilis F9-2, F9-8 and F9-12, and $P$. moraviensis F9-11, exhibited no inhibitory effect on the mycelial growth of $P$. sulcatum.

Furthermore, eleven samples showed significant reduction of mycelial growth of $R$. stolonifer. Among these samples B. subtilis F9-8 and F9-12 and P. koreensis F9-9 exhibited the highest reduction (8\%) in mycelial growth. A group consisting of B. subtilis B9-5, B9-14, F9-2, M9-7, and M9-9, P. proteolytica F9-10, B. badius M9-20, and P. moraviensis F9-11 also reduced the mycelial growth. Three samples including $B$. subtilis CU12, IC10 and $P$. arsenicoxydans F97, showed no inhibitory effect on the mycelial growth of R. stolonifer (Table 5).

Moreover, ten of the fourteen treatments with lipopeptide extracts from antagonistic bacteria showed a marked reduction of the mycelial growth of $V$. dahliae (Table 5). Among the ten lipopeptide extracts, samples from B. subtilis F9-12 and M9-9 and P. moraviensis F9-11 
showed the highest inhibitory activity against $V$. dahliae (82\% inhibition). B. subtilis B9-5, B914, IC10, M9-7, and CU12, P. koreensis F9-9, P. proteolytica F9-10, also significantly inhibited its growth. However, B. subtilis F9-2, F9-8, P. arsenicoxydans F9-7, and B. badius M9-20 revealed no inhibitory effect on the mycelial growth of $V$. dahliae (Table 5). 
Table 5. In vitro inhibitory activities of lipopeptide extracts from Pseudomonas arsenicoxydans F9-7, Pseudomonas koreensis F9-9, Pseudomonas proteolytica F9-10, Pseudomonas moraviensis F9-11, Bacillus subtilis B9-5, B9-14, CU12, F9-2, F9-8, F9-12, IC10, M9-7, and M9-9, and Bacillus badius M9-20 on the mycelial growth of Alternaria solani, Botrytis cinerea, Fusarium sambucinum, Pythium sulcatum, Rhizopus stolonifer and Verticillium dahliae

Mycelial growth inhibition zone (cm)

\begin{tabular}{|c|c|c|c|c|c|c|}
\hline Treatment & A. solani & B. cinerea & F. sambucinum & P. sulcatum & R. stolonifer & V. dahliae \\
\hline Control & $2.0 \pm 0.1 \mathrm{a}$ & $3.5 \pm 0.0 \mathrm{a}$ & $3.4 \pm 0.0 \mathrm{ab}$ & $3.5 \pm 0.0 \mathrm{a}$ & $3.5 \pm 0.0 \mathrm{a}$ & $1.0 \pm 0.0 \mathrm{a}$ \\
\hline B9-5 & $1.5 \pm 0.1 \mathrm{cdef}$ & $3.2 \pm 0.0 \mathrm{bcd}$ & $3.3 \pm 0.1 \mathrm{abcd}$ & $3.0 \pm 0.0 \mathrm{def}$ & $3.4 \pm 0.0 \mathrm{~b}$ & $0.6 \pm 0.1 \mathrm{bcd}$ \\
\hline B9-14 & $1.6 \pm 0.1 \mathrm{bcde}$ & $3.4 \pm 0.0 \mathrm{ab}$ & $2.8 \pm 0.2 \mathrm{de}$ & $3.2 \pm 0.2 \mathrm{cde}$ & $3.4 \pm 0.0 \mathrm{bc}$ & $0.5 \pm 0.1$ cde \\
\hline CU12 & $1.4 \pm 0.1 \mathrm{def}$ & $3.2 \pm 0.1 \mathrm{bcd}$ & $2.6 \pm 0.3 \mathrm{e}$ & $3.0 \pm 0 . \mathrm{efg}$ & $3.5 \pm 0.0 \mathrm{a}$ & $0.5 \pm 0.2 \mathrm{cde}$ \\
\hline IC10 & $1.7 \pm 0.1 b c$ & $3.2 \pm 0.0 \mathrm{bcd}$ & $3.4 \pm 0.1 \mathrm{abc}$ & $3.0 \pm 0.2 \mathrm{efg}$ & $3.5 \pm 0.0 \mathrm{a}$ & $0.6 \pm 0.2 \mathrm{~cd}$ \\
\hline M9-7 & $1.7 \pm 0.1 b c$ & $3.3 \pm 0.0 \mathrm{abc}$ & $2.9 \pm 0.2 \mathrm{cde}$ & $3.1 \pm 0 . \mathrm{def}$ & $3.4 \pm 0.0 \mathrm{~b}$ & $0.5 \pm 0.2 \mathrm{cde}$ \\
\hline M9-9 & $1.3 \pm 0.1 \mathrm{ef}$ & $3.0 \pm 0.3 \mathrm{~d}$ & $3.0 \pm 0.2 \mathrm{abcde}$ & $2.9 \pm 0.2 \mathrm{fg}$ & $3.4 \pm 0.0 \mathrm{~b}$ & $0.2 \pm 0.1 \mathrm{ef}$ \\
\hline F9-2 & $2.0 \pm 0.0 \mathrm{a}$ & $3.5 \pm 0.0 \mathrm{a}$ & $3.2 \pm 0.1 \mathrm{abcde}$ & $3.5 \pm 0.0 \mathrm{abc}$ & $3.4 \pm 0.0 \mathrm{bc}$ & $0.8 \pm 0.1 \mathrm{abc}$ \\
\hline F9-7 & $1.6 \pm 0.0 \mathrm{bcd}$ & $3.3 \pm 0.0 \mathrm{abc}$ & $3.2 \pm 0.1$ abcde & $3.3 \pm 0 . \mathrm{bcd}$ & $3.5 \pm 0.0 \mathrm{a}$ & $0.7 \pm 0 . a b c$ \\
\hline F9-8 & $1.3 \pm 0.0 f$ & $3.4 \pm 0.0 \mathrm{ab}$ & $3.2 \pm 0.1 \mathrm{abcde}$ & $3.5 \pm 0.0 \mathrm{ab}$ & $3.2 \pm 0.1 \mathrm{~d}$ & $0.9 \pm 0.1 \mathrm{ab}$ \\
\hline F9-9 & $2.0 \pm 0.0 \mathrm{a}$ & $3.1 \pm 0.0 \mathrm{~cd}$ & $2.7 \pm 0.4 \mathrm{de}$ & $2.8 \pm 0.0 \mathrm{~g}$ & $3.3 \pm 0.6 \mathrm{~cd}$ & $0.4 \pm 0.1 \mathrm{cde}$ \\
\hline F9-10 & $1.6 \pm 0 . \mathrm{bcd}$ & $3.5 \pm 0.0 \mathrm{a}$ & $3.1 \pm 0.2 \mathrm{abcde}$ & 3.1 \pm 0. def & $3.4 \pm 0.0 \mathrm{~b}$ & $0.50 \pm 0.1 \mathrm{cde}$ \\
\hline
\end{tabular}




\begin{tabular}{|c|l|l|l|l|l|l|}
\hline F9-11 & $1.7 \pm 0 . \mathrm{bc}$ & $3.5 \pm 0.0 \mathrm{a}$ & $3.0 \pm 0.1 \mathrm{bcde}$ & $3.5 \pm 0.0 \mathrm{abc}$ & $3.4 \pm 0.0 \mathrm{~b}$ & $0.30 \pm 0.2 \mathrm{def}$ \\
\hline F9-12 & $1.8 \pm 0 . \mathrm{ab}$ & $3.5 \pm 0.0 \mathrm{a}$ & $3.5 \pm 0.0 \mathrm{a}$ & $3.4 \pm 0.0 \mathrm{abc}$ & $3.1 \pm 0.03 \mathrm{e}$ & $0.07 \pm 0.0 \mathrm{f}$ \\
\hline M9-20 & $1.5 \pm 0 . \mathrm{bcde}$ & $3.3 \pm 0.0 \mathrm{abc}$ & $3.4 \pm 0 . \mathrm{ab}$ & $3.3 \pm 0.9 \mathrm{bcd}$ & $3.4 \pm 0.03 \mathrm{bc}$ & $0.73 \pm 0.1 \mathrm{abc}$ \\
\hline
\end{tabular}

Values are expressed as radial growth of the mycelial in the direction of the disc containing the extracts (averages of three replicates \pm SEM)

Within a column, values sharing the same letter are not significantly different according to Fisher's protected LSD test $(\alpha$ level $=$ 0.05 ). 


\subsection{Effect of lipopeptide extracts on conidial germination}

The fourteen selected lipopeptide extracts were also assayed against conidia to determine the relative activity of the extract against both morphological structures.

All treatments showed a significant inhibition of the conidial germination on A. solani (Table 6). Among the test samples, those from P. arsenicoxydans F9-7, P. koreensis F9-9, P. moraviensis F9-11, B. subtilis isolates B9-14, F9-2, F9-8, F9-12, IC10, and M9-7 (86\% inhibition) exhibited the greatest reduction on conidial germination.

Similarly, all the extracts showed significant decrease on the conidial germination growth of B. cinerea (Table 6). Among the tested extracts, those from P. arsenicoxydans F9-7, P. koreensis F9-9, P. proteolytica F9-10, P. moraviensis F9-11, B. subtilis isolates B9-5, B9-14, CU12, F9-2, F9-8, IC10, M9-7, and B. badius M9-20 (89\%) revealed the greatest reduction in conidial germination.

On the other hand, only six of the fourteen tested isolates showed significant reduction of conidial germination in F. sambucinum (Table 6). B. subtilis B9-5 and F9-8, P. arsenicoxydans F9-7, and P. koreensis F9-9 (76\%) exhibited the highest reduction of $F$. sambucinum conidial germination. B. subtilis F9-2 and M9-9 also exhibited inhibition of $F$. sambucinum conidial germination when compared to the control whereas B. subtilis B9-14, CU12, F9-12, IC10 and M9-7, P. moraviensis F9-11, P. proteolytica F9-10 and B. badius M920 revealed no inhibitory effect on the conidial germination (Table 6).

$B$ subtilis CU12 showed a significant reduction (74\%) of conidial germination of $R$. stolonifer (Table 6). No other tested isolate was significantly inhibitory to $R$. stolonifer conidial germination (Table 6). Finally, thirteen of the tested samples showed marked reduction of $V$. dahliae conidial germination (Table 6). Among the inhibitory extracts, those of $P$. 
arsenicoxydans F9-7, P. koreensis F9-9, P. moraviensis F9-11, B. subtilis isolates B9-14, F9-2, F9-8, F9-12, IC10, M9-7, and B. badius M9-20 revealed the highest inhibitory effect on $V$. dahliae conidial germination (81\% inhibition). B. subtilis M9-9 was the only sample that did not provide inhibitory effects on $V$. dahliae conidial germination (Table 6).

This data was also used to establish any correlation between the effectiveness of the extract in inhibiting mycelial growth and conidial germination (Figure 8). The results indicated no linear correlation, indicating a differential effect of the extract on inhibition of the two morphological structures. 
Table 6. In vitro inhibitory activities of lipopeptide extracts from Pseudomonas arsenicoxydans F9-7, Pseudomonas koreensis F9-9, Pseudomonas proteolytica F9-10, Pseudomonas moraviensis F9-11, Pseudomonas libanensis F9-13, Bacillus subtilis isolates B9-5, B9-14, CU12, F9-2, F9-8, F9-12, IC10, M9-7, M9-9, and Bacillus badius M9-20 on conidial germination of Alternaria solani, Botrytis cinerea, Fusarium sambucinum, Rhizopus stolonifer and Verticillium dahliae

\begin{tabular}{|c|c|c|c|c|c|}
\hline \multicolumn{6}{|c|}{ Conidial germination $(\%)$} \\
\hline Treatment & A. solani & B. cinerea & F. sambucinum & R. stolonifer & V. dahliae \\
\hline Control & $87 \pm 6.1 \mathrm{a}$ & $91 \pm 1.5 a$ & $83 \pm 8.9 a$ & $97 \pm 1.2 \mathrm{a}$ & $90 \pm 3.5 a$ \\
\hline B9-5 & $27 \pm 2.0 \mathrm{cde}$ & $10 \pm 0.7 b c$ & $34 \pm 16$ cde & $84 \pm 7.5 \mathrm{ab}$ & $42 \pm 21 \mathrm{bcd}$ \\
\hline B9-14 & $21 \pm 7.3 \mathrm{cdef}$ & $15 \pm 6.4 \mathrm{bc}$ & $91 \pm 1.7 \mathrm{a}$ & $83 \pm 14 \mathrm{ab}$ & $9.0 \pm 1.0 \mathrm{e}$ \\
\hline CU12 & $37 \pm 15 b c$ & $9.3 \pm 4.4 \mathrm{bc}$ & $90 \pm 3.8 \mathrm{a}$ & $72 \pm 14 b$ & $42 \pm 23 b c$ \\
\hline IC10 & $5 \pm 0.9 f$ & $9.0 \pm 4.0 \mathrm{bc}$ & $80 \pm 13 a$ & $92 \pm 3.2 \mathrm{ab}$ & $20 \pm 1.8 \mathrm{cde}$ \\
\hline M9-7 & $17 \pm 6.5 \mathrm{def}$ & $18 \pm 2.7 b c$ & $87 \pm 1.9 \mathrm{a}$ & $99 \pm 0.7 \mathrm{a}$ & $1.7 \pm 0.3 \mathrm{e}$ \\
\hline M9-9 & $46 \pm 11 b$ & $28 \pm 12 b$ & $64 \pm 20 \mathrm{bcd}$ & $77 \pm 21 \mathrm{ab}$ & $71 \pm 13 \mathrm{ab}$ \\
\hline F9-2 & $4.7 \pm 0.9 f$ & $6.7 \pm 0.9 b c$ & $43 \pm 23 \mathrm{bcd}$ & $97 \pm 1.5 \mathrm{ab}$ & $14 \pm 3.8 \mathrm{cde}$ \\
\hline F9-7 & $11 \pm 5.8 \mathrm{ef}$ & $9.7 \pm 0.7 \mathrm{bc}$ & $20 \pm 5.2 \mathrm{de}$ & $80 \pm 2.9 \mathrm{ab}$ & $13 \pm 4.0 \mathrm{cde}$ \\
\hline F9-8 & $21 \pm 7.9 \mathrm{cdef}$ & $3.7 \pm 0.9 c$ & $6.0 \pm 1 \mathrm{e}$ & $98 \pm 0.6 a$ & $10 \pm 4.4 \mathrm{e}$ \\
\hline F9-9 & $11 \pm 3.2 \mathrm{ef}$ & $6.7 \pm 1.5 b c$ & $35 \pm 10$ cde & $93 \pm 3.3 \mathrm{ab}$ & $10 \pm 5.6 \mathrm{e}$ \\
\hline F9-10 & $16 \pm 4.7 \mathrm{def}$ & $25 \pm 21 b c$ & $76 \pm 4.9 \mathrm{ab}$ & $96 \pm 2.5 a$ & $56 \pm 18 b$ \\
\hline
\end{tabular}




\begin{tabular}{|c|c|c|c|c|}
\hline \multicolumn{2}{|c|}{ Conidial germination (\%) } \\
\hline Treatment & A. solani & B. cinerea & F. sambucinum & R. stolonifer \\
\hline F9-11 & $18 \pm 2.9 \mathrm{def}$ & $5.7 \pm 1.9 \mathrm{bc}$ & $65 \pm 16 \mathrm{abc}$ & $95 \pm 2.0 \mathrm{~b}$ \\
\hline F9-12 & $15 \pm 3.9 \mathrm{def}$ & $28 \pm 18 \mathrm{~b}$ & $70 \pm 23 \mathrm{abc}$ & $88 \pm 3.8 \mathrm{ab}$ \\
\hline M9-20 & $34 \pm 3.0 \mathrm{bcd}$ & $9.7 \pm 5.7 \mathrm{bc}$ & $94 \pm 0.7 \mathrm{a}$ & $97 \pm 0.3 \mathrm{ab}$ \\
\hline
\end{tabular}

Values are percent conidial germination (average of three replicates \pm SEM)

Within a column, values sharing the same letter are not significantly different according to Fisher's protected LSD test $(\alpha$ level $=0.05$ 


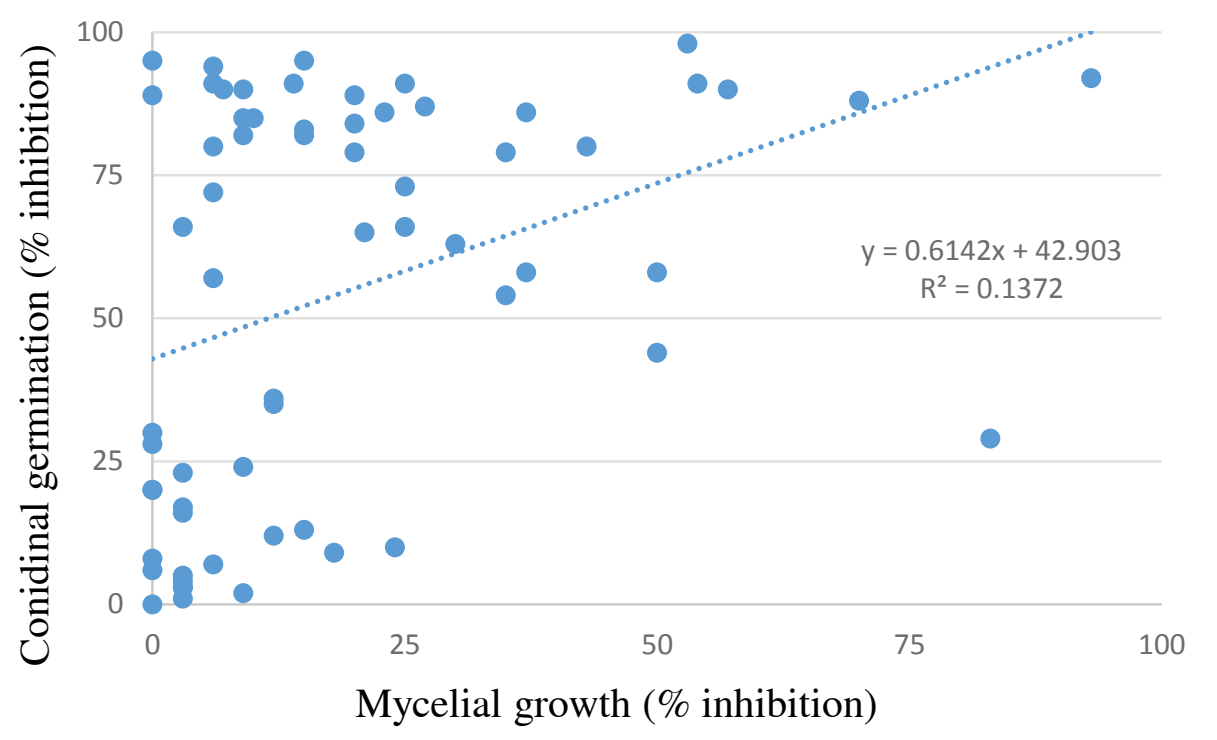

Figure 8. Correlation between reduction of mycelial growth and conidial germination (\% inhibition) of the pathogens. Data were obtained from Table 6 and 7. Presented data are means from three biological repeats

\subsection{Identification of lipopeptides in the extracts}

LC-MS was performed on lipopeptide fractions from $\mathrm{C}_{18}$ cartridges. Results showed that lipopeptides were concentrated in fractions F4 and F5 and eluted with 80 and 100\% methanol, respectively. Fengycin homologs were produced by B. subtilis B9-1, CU12, IC10, M9-7, M9-9, B9-5, M9-4, M9-14, B9-14, B9-7, B9-9A, B. megaterium M9-1B and B. badius M9-20, as well as by Bacillus-related species P. favisporus B9-4, B. borstelensis M9-18, and R. pycnus M9-19. In Bacillus and Bacillus-related spp., LC-MS data showed multiple fengycin homologs with side chain lengths from $\mathrm{C}_{13}-\mathrm{C}_{19}$. The most common side chains observed were $\mathrm{C}_{16}$ and $\mathrm{C}_{18}$ with fengycin molecular weight of 1463 and $1491 \mathrm{Da}$. Both protonated ion peaks $\left([\mathrm{M}+\mathrm{H}]^{+}\right.$ions 1463 , 1477 , and 1491) and sodiated ion peaks $\left([\mathrm{M}+\mathrm{Na}]^{+}\right.$ions 1485,1499 and 1514), observed in fractions from B. subtilis CU12, M9-4, and M9-14, varied by $14 \mathrm{Da}\left(\mathrm{CH}_{2}-\right)$ indicating fengycin homologs with identical peptide sequence, but variable beta hydroxyl fatty acid chain lengths (Table 7) (Malfanova et al., 2012). 
Additionally, LC-MS data showed the presence of iturin in B. subtilis F9-8, M9-9, and CU12 (Table 8). The homologs of iturin identified had side chain length of $\mathrm{C}_{14}, \mathrm{C}_{15}, \mathrm{C}_{16}, \mathrm{C}_{17}$ and $\mathrm{C}_{18}$. The most common homologs were $\mathrm{C}_{14}$ and $\mathrm{C}_{17}$ with molecular weight 1043 and 1085 Da and is consistent with data from literature (Velho et al., 2011; Zhang et al., 2012)

Moreover, the LC-MS analysis showed the presence of surfactin. Surfactin peaks were observed in the following bacteria: B. subtilis B9-1, F9-2, F9-8, M9-7, M9-9, F9-12, M9-3, M94, M9-14, B9-8, B9-7, B9-9A, IC10 and IB16, B. badius M9-20, B. borstelensis M9-18, $R$. pycnus M9-19, B. licheniformis PSA1 and B. megaterium B9-4 and M9-1B (Table 9). The most common protonated ions $\left([\mathrm{M}+\mathrm{H}]^{+}\right)$were $994,1008,1022,1036,1050$ and 1064 Da indicating homologs with side chains of $\mathrm{C}_{13}-\mathrm{C}_{18}$. The most common sodiated adducts $\left([\mathrm{M}+\mathrm{Na}]^{+}\right)$were $1016,1030,1044$, and 1058 corresponding to surfactin homologs with side chain of $\mathrm{C}_{13}-\mathrm{C}_{16}$ (Table 9). Overall, the most commonly occurring family cyclic lipopeptide in the Bacillus and Bacillus-related spp. was surfactin followed by fengycin and lastly iturin.

B. subtilis CU12 and M9-9 revealed the presence of all three families (surfactin, iturin, and fengycin). B. subtilis F9-8 produced iturin and surfactin, but not fengycin. Moreover, $B$. subtilis B9-1, M9-7, IC10, M9-3, M9-4, M9-14, B9-14, B9-7 and B9-9A, B. badius M9-20, B. borstelensis M9-18, R. pycnus M9-19 and B. megaterium B9-4 and M9-1B produced fengycin and surfactin, but not iturin. Other extracts from B. subtilis F9-2, F9-12, IB16, B9-8, and M9-3 and B. licheniformis PSA1 produced only surfactin, while B. subtilis B9-5, produced only fengycin (Table 7 and Table 9).

In Pseudomonas spp. isolates, amphisin was produced by $P$. moraviensis $\mathrm{F9}-11$ and $P$. koreensis F9-9. LC-MS analysis showed amphisin homologs from $\mathrm{C}_{9}-\mathrm{C}_{13}\left([\mathrm{M}+\mathrm{H}]^{+}\right.$ions 1326 , $1340,1354,1368$, and $1382 \mathrm{Da}$ ), with the most observed homolog being $\mathrm{C}_{11}$ (1354 Da) (Table 
10). The data also showed that $P$. moraviensis F9-11 also produced putisolvin (Table 10), with side chains of $\mathrm{C}_{6}$ and $\mathrm{C}_{7}$ with molecular weight of 1380 and $1393 \mathrm{Da}$, respectively (Table 10).

Finally, P. gessardii B9-3 and M9-16, P. moraviensis F9-6, P. arsenicoxydans F9-7, P. moraviensis F9-10, and P. libanensis F9-13 did not reveal any known Pseudomonas lipopeptides from the amphisin, putisolvin, viscosin or syringomycin families. 
Table 7. Fengycin homologs detected by LC-MS in Bacillus and Bacillus-related species.

\begin{tabular}{|c|c|c|c|}
\hline 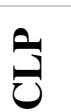 & $\begin{array}{c}\text { Molecular mass }[\mathrm{M}-\mathrm{H}]^{+} \\
/[\mathrm{M}+\mathrm{Na}]^{+}\end{array}$ & Homolog & Microorganism \\
\hline \multirow{19}{*}{ 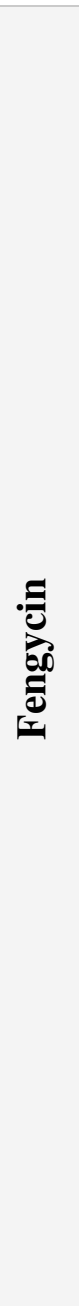 } & $1463,1477,1491,1505$ & $\mathrm{C} 16, \mathrm{C} 17, \mathrm{C} 18, \mathrm{C} 19$ & Bacillus badius M9-20 \\
\hline & $1462,1476,1490$ & $\mathrm{C} 16, \mathrm{C} 17, \mathrm{C} 18$ & Bacillus subtilis CU12 \\
\hline & $\begin{array}{c}1441,1454,1467,1481 \\
1495,1508\end{array}$ & $\begin{array}{c}\mathrm{C} 14, \mathrm{C} 15, \mathrm{C} 16, \mathrm{C} 17, \\
\mathrm{C} 18, \mathrm{C} 19\end{array}$ & Bacillus subtilis M9-7 \\
\hline & $1462,1476,1490$ & $\mathrm{C} 16, \mathrm{C} 17, \mathrm{C} 18$ & Bacillus subtilis M9-9 \\
\hline & 1449,1463 & $\mathrm{C} 15, \mathrm{C} 16$ & Bacillus subtilis IC-10 \\
\hline & $1463,1477,1491$ & $\mathrm{C} 16, \mathrm{C} 17, \mathrm{C} 18$ & $\begin{array}{c}\text { Paenibacillus favisporus } \\
\text { B9-4 }\end{array}$ \\
\hline & $\begin{array}{c}1448,1461,1475,1489 \\
1503,1517\end{array}$ & $\begin{array}{l}\mathrm{C} 15, \mathrm{C} 16, \mathrm{C} 17 \\
\mathrm{C} 18, \mathrm{C} 19, \mathrm{C} 20\end{array}$ & $\begin{array}{c}\text { Brevibacillus borstelensis } \\
\text { M9-18 }\end{array}$ \\
\hline & $1461,1475,1489$ & $\mathrm{C} 16, \mathrm{C} 17, \mathrm{C} 18$ & \multirow{2}{*}{$\begin{array}{l}\text { Rummeliibacillus pycnus M9- } \\
19\end{array}$} \\
\hline & $1479,1493,1507$ & $\mathrm{C} 17, \mathrm{C} 18, \mathrm{C} 19$ & \\
\hline & $1479,1493,1506$ & $\mathrm{C} 17, \mathrm{C} 18, \mathrm{C} 19$ & \multirow[t]{3}{*}{ Bacillus subtilis M9-4 } \\
\hline & $1463,1477,1491$ & $\mathrm{C} 16, \mathrm{C} 17, \mathrm{C} 18$ & \\
\hline & $1485,1499,1514$ & $\mathrm{C} 18, \mathrm{C} 19, \mathrm{C} 20$ & \\
\hline & $1463,1477,1491,1506$ & C16, C17, C18, C19 & Bacillus subtilis M9-14 \\
\hline & $\begin{array}{c}1449,1463,1477,1491 \\
1505\end{array}$ & $\begin{array}{c}\mathrm{C} 15, \mathrm{C} 16, \mathrm{C} 17, \mathrm{C} 18, \\
\mathrm{C} 19\end{array}$ & Bacillus subtilis B9-14 \\
\hline & $1448,1462,1476,1489$ & $\mathrm{C} 15, \mathrm{C} 16, \mathrm{C} 17, \mathrm{C} 18$ & Bacillus subtilis B9-7 \\
\hline & $1464,1478,1492,1506$ & $\mathrm{C} 16, \mathrm{C} 17, \mathrm{C} 18, \mathrm{C} 19$ & Bacillus subtilis B9-9B \\
\hline & 1463,1491 & $\mathrm{C} 16, \mathrm{C} 18$ & $\begin{array}{c}\text { Bacillus megaterium } \\
\text { M9-1B }\end{array}$ \\
\hline & $\begin{array}{c}1448,1464,1478,1492 \\
1506\end{array}$ & $\begin{array}{c}\mathrm{C} 15, \mathrm{C} 16, \mathrm{C} 17, \mathrm{C} 18, \\
\mathrm{C} 19\end{array}$ & Bacillus subtilis B9-1 \\
\hline & 1504,1521 & $\mathrm{C} 17, \mathrm{C} 18$ & Bacillus subtilis B9-5 \\
\hline
\end{tabular}


Table 8. Iturin homologs detected by LC-MS in Bacillus and Bacillus-related species.

\begin{tabular}{|c|c|c|c|}
\hline 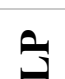 & Molecular mass $[\mathrm{M}-\mathrm{H}]^{+}$ & Homolog & Microorganism \\
\hline \multirow{6}{*}{ 葛 } & 1043,1057 & $\mathrm{C} 14, \mathrm{C} 16$ & \multirow{2}{*}{ Bacillus subtilis F9-8 } \\
\hline & 1079,1093 & $\mathrm{C} 17, \mathrm{C} 18$ & \\
\hline & 1044,1085 & $\mathrm{C} 14, \mathrm{C} 17$ & \multirow{2}{*}{ Bacillus subtilis M9-9 } \\
\hline & 1049,1063 & $\mathrm{C} 14, \mathrm{C} 15$ & \\
\hline & 1084,1099 & $\mathrm{C} 17, \mathrm{C} 18$ & \multirow[t]{2}{*}{ Bacillus subtilis CU12 } \\
\hline & 1069,1083 & C16, C17 & \\
\hline
\end{tabular}


Table 9. Surfactin homologs detected by LC-MS in Bacillus and Bacillus-related species.

\begin{tabular}{|c|c|c|c|}
\hline$\theta$ & $\begin{array}{c}\text { Molecular mass }[\mathrm{M}-\mathrm{H}]^{+} / \\
{[\mathrm{M}+\mathrm{Na}]^{+}}\end{array}$ & Homolog & Microorganism \\
\hline \multirow{22}{*}{ 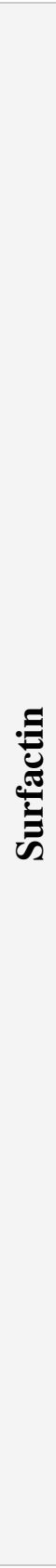 } & $994,1008,1022,1036$ & $\mathrm{C} 13, \mathrm{C} 14, \mathrm{C} 15, \mathrm{C} 16$ & Bacillus subtilis F9-2 \\
\hline & $994,1008,1022,1036$ & $\mathrm{C} 13, \mathrm{C} 14, \mathrm{C} 15, \mathrm{C} 16$ & Bacillus subtilis F9-8 \\
\hline & $994,1008,1022,1036,1050$ & $\begin{array}{c}\mathrm{C} 13, \mathrm{C} 14, \mathrm{C} 15, \mathrm{C} 16, \\
\mathrm{C} 17\end{array}$ & Bacillus badius M9-20 \\
\hline & $994,1008,1022,1036,1050$ & $\begin{array}{c}\mathrm{C} 13, \mathrm{C} 14, \mathrm{C} 15, \mathrm{C} 16 \\
\mathrm{C} 17\end{array}$ & Bacillus subtilis M9-7 \\
\hline & $1008,1022,1036$ & $\mathrm{C} 14, \mathrm{C} 15, \mathrm{C} 16$ & Bacillus subtilis M9-9 \\
\hline & $922,950,964,992$ & C8, C10, C11, C13 & Bacillus subtilis IC-10 \\
\hline & $994,1008,1022,1036,1050$ & $\begin{array}{c}\mathrm{C} 13, \mathrm{C} 14, \mathrm{C} 15, \mathrm{C} 16 \\
\mathrm{C} 17\end{array}$ & Bacillus subtilis F9-12 \\
\hline & $994,1008,1022,1036,1050$ & $\begin{array}{c}\mathrm{C} 13, \mathrm{C} 14, \mathrm{C} 15, \mathrm{C} 16 \\
\mathrm{C} 17\end{array}$ & $\begin{array}{l}\text { Paenibacillus favisporus } \\
\text { B9-4 }\end{array}$ \\
\hline & $\begin{array}{c}994,1008,1022,1036,1050 \text {, } \\
1064\end{array}$ & $\begin{array}{c}\mathrm{C} 13, \mathrm{C} 14, \mathrm{C} 15, \mathrm{C} 16, \\
\mathrm{C} 17, \mathrm{C} 18\end{array}$ & $\begin{array}{c}\text { Brevibacillus borstelensis } \\
\text { M9-18 }\end{array}$ \\
\hline & 994, 1008, 1022, 1036 & $\mathrm{C} 13, \mathrm{C} 14, \mathrm{C} 15, \mathrm{C} 16$ & $\begin{array}{c}\text { Bacillus megaterium } \\
\text { B9-9B }\end{array}$ \\
\hline & $994,1008,1022,1036,1050$ & $\begin{array}{c}\mathrm{C} 13, \mathrm{C} 14, \mathrm{C} 15, \mathrm{C} 16, \\
\mathrm{C} 17\end{array}$ & $\begin{array}{c}\text { Rummeliibacillus pycnus } \\
\text { M9-19 }\end{array}$ \\
\hline & $994,1008,1022,1036$ & $\mathrm{C} 13, \mathrm{C} 14, \mathrm{C} 15, \mathrm{C} 16$ & $\begin{array}{c}\text { Bacillus subtilis } \\
\text { M9-3 }\end{array}$ \\
\hline & $994,1008,1022,1036$ & $\mathrm{C} 13, \mathrm{C} 14, \mathrm{C} 15, \mathrm{C} 16$ & Bacillus subtilis M9-4 \\
\hline & $994,1008,1022,1036,1050$ & $\begin{array}{c}\mathrm{C} 13, \mathrm{C} 14, \mathrm{C} 15, \mathrm{C} 16 \\
\mathrm{C} 17\end{array}$ & Bacillus subtilis M9-14 \\
\hline & 994, 1008, 1022, 1036 & $\mathrm{C} 13, \mathrm{C} 14, \mathrm{C} 15, \mathrm{C} 16$ & Bacillus subtilis B9-7 \\
\hline & $994,1008,1022,1036$ & $\mathrm{C} 13, \mathrm{C} 14, \mathrm{C} 15, \mathrm{C} 16$ & Bacillus subtilis B9-8 \\
\hline & $994,1008,1022,1036$ & $\mathrm{C} 13, \mathrm{C} 14, \mathrm{C} 15, \mathrm{C} 16$ & Bacillus subtilis B9-9A \\
\hline & $994,1008,1022,1036$ & C13, C14, C15, C16 & Bacillus subtilis IB-16 \\
\hline & $994,1008,1022,1036$ & $\mathrm{C} 13, \mathrm{C} 14, \mathrm{C} 15, \mathrm{C} 16$ & $\begin{array}{c}\text { Bacillus licheniformis } \\
\text { PSA1 }\end{array}$ \\
\hline & $994,1008,1022,1036$ & C13, C14, C15, C16 & $\begin{array}{c}\text { Bacillus megaterium } \\
\text { M9-1B }\end{array}$ \\
\hline & $994,1008,1022,1036$ & $\mathrm{C} 13, \mathrm{C} 14, \mathrm{C} 15, \mathrm{C} 16$ & Bacillus subtilis CU12 \\
\hline & $1008,1022,1036$ & C14, C15, C16 & $\begin{array}{l}\text { Bacillus subtilis } \\
\text { B9-1 }\end{array}$ \\
\hline
\end{tabular}


Table 10. Amphisin and putisolvin homologs detected by LC-MS in Pseudomonas species.

\begin{tabular}{|c|c|c|c|}
\hline 己 & Molecular mass $[\mathrm{M}-\mathrm{H}]^{+}$ & Homolog & Microorganism \\
\hline \multirow{3}{*}{$\frac{.}{\frac{\mathrm{g}}{\mathrm{Z}}}$} & $\begin{array}{c}1326,1340,1354,1368 \\
1382\end{array}$ & $\begin{array}{l}\text { C9, C10, C11, } \\
\text { C12, C13 }\end{array}$ & \multirow[t]{2}{*}{$\begin{array}{c}\text { Pseudomonas koreensis } \\
\text { F9-9 }\end{array}$} \\
\hline & $1376,1390,1404$ & $\mathrm{C} 12, \mathrm{C} 13, \mathrm{C} 14$ & \\
\hline & $1326,1340,1354,1368$ & $\begin{array}{c}\mathrm{C} 9, \mathrm{C} 10, \mathrm{C} 11, \\
\mathrm{C} 12\end{array}$ & $\begin{array}{c}\text { Pseudomonas moraviensis } \\
\text { F9-11 }\end{array}$ \\
\hline \multirow{2}{*}{ 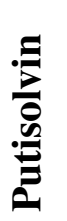 } & $1354,1382,1397$ & C4, C6, C7 & \multirow[b]{2}{*}{$\begin{array}{c}\text { Pseudomonas moraviensis } \\
\text { F9-11 }\end{array}$} \\
\hline & 1380,1393 & C6, C7 & \\
\hline
\end{tabular}




\section{Chapter 4: Discussion}

Currently, with increasing awareness of possible deleterious effect of fungicides on the ecosystem, there is a growing interest in pesticide-free agricultural products (David, 2008). A major challenge in plant pathology is to introduce or develop new strategies to control plant diseases as more traditional controls and methods become obsolete (Pal and Gardener, 2006), and to create solutions that reduce or exclude the use of synthetic chemical products. As an alternative to the use of synthetic chemicals, biological control offers many advantages to growers and to society. Among the benefits, biocontrol is generally deemed a more sustainable and safer method to produce and preserve food. An important aspect for commercial purposes that should be kept in mind is that in order for biocontrol products to be accepted in agricultural communities, they must be safe and economical (Wilkinson and Fitzgerald, 1997). These issues can be addressed by understanding how the biological controls agents act, their inhibitory properties, and through the understanding and analysis of the production of antimicrobial secondary metabolites. Such antimicrobial compounds are widespread in nature and are produced by a wide spectrum of microorganisms. Compounds that are produced by biocontrol agents as treatments for plant pathogens may have advantages over their synthetic counterparts because they are often more biodegradable, effective at extreme temperatures and $\mathrm{pH}$ values (Cameotra and Makkar, 1998), and may be more active and selective as membrane-

permeabilizers (Nielsen et al., 2009). In the past few years, biocontrol agents from Bacillus and Pseudomonas isolates have become a highly effective and environmentally friendly alternative to traditional pesticides. The antimicrobial activities are linked, in part, to the production of molecules that have the ability to suppress plant diseases. 
This study was carried out to investigate the antifungal ability of various bacterial isolates that inhibit the in vitro growth of plant pathogens and to gain further knowledge on the means by which these bacterial antagonists exert their antifungal activity.

\subsection{Evaluation of various bacterial antagonists through general plate inhibition assays}

Forty bacterial isolates were tested in vitro for their ability to reduce the mycelial growth of six plant pathogens: A. solani, B. cinerea, F. sambucinum, $P$. sulcatum, $R$. stolonifer and $V$. dahliae. Among the eighteen different species of bacteria that were tested for inhibitory properties, sixteen showed significant reduction of the mycelial growth of at least one of the six pathogens. The presence of an inhibition zone in solid culture media indicated that growth reduction was most likely due to the production of diffusible extracellular metabolites.

All six tested Pseudomonas spp. were members of the P.fluorescens group (Mulet et al., 2010) and showed marked reduction of the pathogens. P. gessardii, $P$. moraviensis, $P$. arsenicoxydans, $P$. koreensis, $P$. proteolytica and $P$. libanensis caused significant reduction in growth of at least three of the plant pathogens. Of particular note, $P$. proteolytica $\mathrm{F} 9-10$ and $P$. libanensis F9-13 were generally the best inhibitors of pathogen growth of all the bacterial antagonists tested. Previous studies have shown that different Pseudomonas spp. have the ability to reduce the mycelial growth of many plant pathogens (Haas and Defago, 2005) including those from genera tested in this study. For example, $P$. fluorescens has been reported to inhibit Pythium ultimum (Mezaache-Aichour et al., 2012), and A. solani (El Sayed et al., 2008) mycelial growth in vitro. Other Pseudomonas spp. were reported to inhibit the mycelial growth of $B$. cinerea (Bryk et al., 2004), V.dahliae (Martin-Lapierre, 2011; Trivedi, 2007) and Fusarium spp. (Duijff 
et al., 1993). To our knowledge, this is the first time that mycelial inhibition of $R$. stolonifer by Pseudomonas spp. has been reported.

In addition to Pseudomonas spp., three of the four Bacillus spp. tested (thirteen isolates of B. subtilis, two isolates of B. megaterium and one isolate of B. licheniformis), showed inhibition of at least one of the tested plant pathogens. Bacillus spp. are well-known for their ability to reduce the growth of plant pathogens (Ongena and Jacques, 2008; Falardeau et al. 2013). For example, B. subtilis has been previously shown to inhibit the growth of $A$. solani and B. cinerea (Wise et al., 2012; On et al., 2015) as well as F. sambucinum and P. sulcatum (Wise et al., 2012). Previous studies have also shown that B. licheniformis was antagonistic to Alternaria alternata and Fusarium solani (Lira-de León et al., 2014). B. megaterium has previously shown inhibitory effects on the growth of Aspergillus flavus (Kong et al., 2014). Although B. badius had previously shown inhibitory effects on $V$. dahliae (Martin-Lapierre, 2011), it did not inhibit mycelial growth of the plant pathogen in our test conditions.

Among the non-Bacillus bacteria isolated from compost teas, A. aminovorans IB2 and A. kashmirensis IC6 both decreased the mycelial growth of the six tested pathogens and $B$. iodinum isolates inhibited 1 or 2 of these pathogens. Previous work reported that these bacterial isolates inhibited the mycelial growth of $A$. solani and B. cinerea (On et al., 2015). To our knowledge, this is the first report of A. aminovorans, A. kashmirensis and B. iodinum inhibiting the growth of $F$. sambucinum, P. sulcatum, R. stolonifer and V.dahliae (Table 4).

In Arthrobacter spp. tested in this study, A. humicola M9-2 decreased the mycelial growth of all the fungal pathogens tested except F. sambucinum. Furthermore, A. humicola M91A showed inhibition to $F$. sambucinum and $V$. dahliae and A. humicola M9-8 reduced the growth of $F$. sambucinum and B. cinerea. Finally, A. psychrophenolicus revealed inhibition of 
all the tested pathogens with exception of $A$. solani and P. sulcatum (Table 4). Previous work showed that Arthrobacter citreus, Arthrobacter nicotianae, Arthrobacter oxydans, Arthrobacter viscosus and an unidentified Arthrobacter sp. have been shown to possess activity against plant pathogens such as F. oxysporum, Cylindrocarpon destructans and Pythium spp. (Axelrood et al., 1996).

The remaining isolates B. borstelensis (Wang et al., 2015), P. favisporus (Velázquez et al., 2004) and R. pycnus (Vaishampayan et al., 2009) are aerobic spore-forming bacteria that are related to Bacillus. B. borstelensis M9-18 and R. pycnus M9-19 both reduced the mycelial growth of five pathogens (but not P. sulcatum) (Table 4). To the best of our knowledge this is the first report that these bacteria have antagonistic activities against plant pathogens, however it has been reported previously that a strain of B. borstelensis was inhibitory to foodborne microorganisms that include Listeria monocytogenes, B. subtilis, Clostridium perfringens, Staphylococcus aureus, and others (Sharma et al., 2014). P. favisporus did not inhibit any of the tested plant pathogens in our test conditions. Other studies showed that the Paenibacillus genus displayed efficient biocontrol activity against oomycete pathogens (Li et al., 2007).

Finally, we also compared the relative inhibitory activity of the different bacterial groups which revealed that the Pseudomonas spp. group exhibited higher inhibitory activity than the Bacillus spp. and Bacillus-related spp. group. These two groups were also more inhibitory to the pathogens than the group composed of the tested bacterial species (Figure 7). The higher inhibitory effect of Pseudomonas spp. is likely because the group produce various potent antimicrobial compounds such as those from the two families of lipopeptides (amphisin and putisolvin) identified in our work (Table 10). Some Pseudomonas spp. also showed inhibitory effects against the pathogens, but did not reveal lipopeptides from the families of amphisin, 
putisolvin, syringomycin and viscosin. Their activity may be due to the presence of other reported inhibitory compound such as $\mathrm{HCN}$, siderophores, phenazine (Haas and Defago, 2005) and proteases (Bruijin and Raaujmakers, 2009). Further investigation is needed to identify the presence of these antimicrobial compounds from our four isolates. As mentioned previously, all lipopeptide extracts from Bacillus and Bacillus-related spp. revealed the presence at least of one of the three families of lipopeptide fengycin, iturin or surfactin. We hypothesized that inhibitory activities from Bacillus and Bacillus-related spp., are due, at least in part, to the presence of the lipopeptides. However, the presence of other bioactive compounds may also be implicated in the observed activity (Wise et al., 2012).

\subsection{Effect of lipopeptide extracts on mycelial growth}

Lipopeptide samples from the four Pseudomonas isolates (P.arsenicoxydans F9-7, $P$. koreensis F9-9, P. proteolytica F9-10, and P. moraviensis F9-11) significantly inhibited the mycelial growth of two out of six of the tested pathogens in vitro. This suggested that extracellular antimicrobial products were released when the bacteria were confronted with a competing microorganism. Previous work showed that extracts from Pseudomonas chlororaphis resulted in the inhibition of the growth of $P$. ultimum and $F$. oxysporum (Mezaache-Aichour et al., 2012). Moreover, P. fluorescens isolates were previously shown to produce antibiotics as well as volatile compounds such as hydrogen cyanide that decreased the mycelial growth of $V$. dahliae (Tehrani et al., 2001). Another study showed that a Pseudomonas chlororaphis strain producing pyrrolnitrin was able to control the spread of B. cinerea in tomatoes (Ajouz et al., 2011). Furthermore, Pseudomonas isolates producing phenazine-1-carboxylic acid were shown 
to be inhibitory to A. solani (El Sayed et al., 2008). This is, to the best of our knowledge, the first report of compounds from Pseudomonas inhibiting the growth of $R$. stolonifer.

The tested Bacillus spp. isolates demonstrated that the lipopeptide extracts were also inhibitory to at least one of the pathogen assayed. Our laboratory previously indicated similar results showing extracts from $B$. subtilis were able to reduce the mycelial growth of $A$. solani, B. cinerea, and P. sulcatum (Wise et al., 2012). In addition, On et al. (2015) showed that extracts from $B$. subtilis inhibited mycelial growth of $A$. solani and B. cinerea. Multiple isolates of $B$. subtilis (B9-5, B9-14, M9-7, M9-9, F9-2, F9-8, and F9-12) as well as B. badius M9-20 inhibited the growth of $R$. stolonifer in this work. A previous study showed the in vitro antagonistic effect of another Bacillus species (B. amyloliquefaciens) on the mycelial growth of B. cinerea, $P$. expansum and $R$. stolonifer due to the presence of antifungal secondary metabolites in its culture filtrates (Arrebola et al., 2009).

Two bacterial isolates $B$. badius M9-20 and P. favisporus B9-4 showed no inhibitory effect against of the six pathogens (Table 4), but the samples from B. badius M9-20 showed inhibitory properties against mycelial growth of the pathogens. It is hypothesized that these bacterial isolates were not effective in inhibiting the growth of the mycelium because the antimicrobial compounds were produced at a low concentration by the bacterium when the bacteria and pathogens were confronted on Petri dishes whereas extracts were enriched in lipopeptide that are known to possess antifungal activity. Moreover, the lower concentration of antimicrobial compounds produced by these bacterial isolates may be completely degraded by the pathogens (no inhibition) (Sonnenbichler et al., 1997; Martinez et al., 2006), whereas a higher concentration is more difficult to degrade completely, thus providing inhibition. 


\subsection{Antifungal activity of lipopeptide extracts on fungal pathogen conidial germination}

Extracts from P. arsenicoxydans F9-7, P. koreensis F9-9, P. proteolytica F9-10, and $P$. moraviensis F9-11 reduced the amount of conidial germination in A. solani, B. cinerea, and $V$. dahliae. $P$. arsenicoxydans F9-7 and $P$. koreensis F9-9 extracts also reduced the conidial germination of $F$. sambucinum. Previous work showed that culture filtrate of $P$. fluorescens inhibited spore germination in A. alternata, Curvularia andropogonis, Fusarium moniliforme and Colletotrichum acutatum (Mishra et al., 2011). Previous work also indicated that $P$. chlororaphis producing pyrrolnitrin was able to inhibit spore germination of B. cinerea (Ajouz et al., 2011). Furthermore, this is, to the best of our knowledge, the first report of compounds from Pseudomonas showing inhibitory effect on the conidial germination of $V$. dahliae.

Extracts from various isolates of $B$. subtilis as well as B. badius M9-20 reduced the spore germination in A. solani, B. cinerea and V. dahliae. Previous work showed that extracts from a strain of $B$. subtilis also inhibited the spore germination of $A$. solani and $B$. cinerea (On et al., 2015). Moreover, samples from isolates B. subtilis B9-5, M9-9, F9-2 and F9-8, decreased the conidial germination of $F$. sambucinum. Previous work showed that volatile compounds from B. amyloliquefaciens also inhibited the spores of F. oxysporum (Yuan et al., 2012). Lastly, samples from the strain B. subtilis CU12 and M9-9, showed decreased growth rate on the conidial germination of $R$. stolonifer. A previous study showed that B. subtilis compounds reduced the conidial germination of $R$. stolonifer (Zhou et al., 2011). To the best of our knowledge, this is the first report of Bacillus compounds inhibiting $V$. dahliae conidial germination. 


\subsection{Correlation of lipopeptides extracts and inhibitory effects}

The effect of fourteen lipopeptide extracts from the bacterial isolates of Bacillus, Bacillus-related and Pseudomonas spp. showed inhibitory activities against mycelial growth and conidial germination with conidial germination showing higher sensitivity to the extracts. We hypothesized that lipopeptide extracts have more significant effects on the early stages of the plant pathogen development (i.e., the fragile germinating conidium) compared to the more tough structure that is the mycelium. There was no correlation between the inhibition of mycelium growth and conidial germination, indicating that extracts did not affect these two morphological structures in the same way (Figure 8). Therefore, it would seem necessary to perform antimicrobial testing on both structures in order to more completely understand the inhibitory activity of the extracts.

\subsection{Identification of lipopeptides in extracts from bacterial antagonists}

The success of biocontrol depends on the screening process for the biocontrol agent, such as its potential ability to produce antimicrobial compounds, which can affect its ability to survive in different environments containing multiple biotic and abiotic stressors (Pal et al., 2006; Delfosse, 2005). Lipopeptides extracts from thirty two bacterial isolates were submitted to reverse-phase column chromatography and were screened for the presence of known lipopeptides using LC-MS. In this study, we have described the use of Bacillus, Bacillus-related and Pseudomonas spp. isolates that showed inhibitory activity against plant pathogens. It is well known that several species of Bacillus and Pseudomonas are capable of producing biologically active molecules (Chen et al., 2009; Niu et al., 2011; Rückert et al., 2011), including lipopeptides (Gardener, 2004). LC-MS analysis showed the presence the three lipopeptides families 
(fengycin, iturin, and surfactin) in Bacillus or Bacillus-related spp. Every isolate tested produced lipopeptides belonging to one, two or all three main Bacillus lipopeptide families.

Some isolates showed inhibitory activities against the tested pathogens and showed the presence of lipopeptides. Specifically, B. subtilis B9-1, B9-5, and B9-14 and B. megaterium M91B produced fengycin, B. subtilis B9-9A, F9-12, F9-2, B9-8 and IB16 and B. licheniformis PSA1 produced surfactin, B. subtilis B9-7, M9-4 and M9-7, R. pycnus M9-19 and B. borstelensis M918 and B. megaterium B9-9B produce fengycin and surfactin, B. subtilis F9-8 produce surfactin and iturin, and B. subtilis CU12 and M9-9 produce fengycin, iturin and surfactin as possible compounds leading to their inhibitory effects on the pathogens. Previous studies showed that $B$. subtilis and B. amyloliquefaciens revealed the presence of lipopeptides fengycin, iturin, and surfactin (Cawoy et al., 2014). A previous study also demonstrated that Paenibacillus spp. IIRAC30 produced surfactins, which proved to be effective in controlling $R$. solani in vitro, through its ability to form pores in membranes (Canova et al., 2010; Mandal et al., 2013). Other work done on characterization of lipopeptides from B. licheniformis revealed the production of the fengycin and surfactin families (Pecci et al., 2010; Thaniyavarn et al., 2003). Additionally, Brevibacillus brevis, a species of Brevibacillus different from the one we tested in our study, was shown to produce the surfactin family of lipopeptides (Wang et al., 2010). R. pycnus M919, B. badius M9-20 and B. borstelensis M9-18, revealed the presence of these lipopeptides (fengycins, iturins or surfactins) and are reported, to the best of our knowledge, for the first time.

The Pseudomonas isolates exhibited the presence of two families of lipopeptides. $P$. koreensis F9-9 revealed the presence of the amphisin family and P. moraviensis F9-11 showed both the amphisin family and the putisolvin family. Because we observed the antagonistic effect of these two bacterial isolates, we attributed the inhibitory activity to the production of these 
antimicrobial lipopeptides that are present in the samples. However, other types of antimicrobial compounds may also contribute to the observed inhibitory activity. Many studies have linked Pseudomonas lipopeptides and their major role in inhibiting plant pathogens. Cyclic lipopeptides produced by $P$. fluorescens strains showed the production of amphisin (Gross and Loper, 2009), while isolates such as $P$. putida produced lipopeptides that belong to the putisolvin family (Kuiper et al., 2003).

P. moraviensis F9-6, P. arsenicoxydans F9-7, P. gessardii B9-3 and M9-16, $P$. proteolytica F9-10, and P. libanensis F9-13 showed inhibition through confrontation assays, but no production of lipopeptides was detected. This result may be because of the production of other types of secondary metabolites that were not screened using our identification methodology. Some of the more common antimicrobial compounds such as 2,4diacetylphloroglucinol and phenazine (Trivedi, 2007) may be responsible for this observed inhibition. We also hypothesize that the media used for inducing lipopeptides production (MOLP) was developed for the isolation of Bacillus lipopeptides. Its use may therefore not be optimal for isolation of lipopeptides from Pseudomonas.

Two bacterial isolates $B$. badius M9-20 and P. favisporus B9-4 showed no inhibitory effect against any of the six pathogens (Table 4), but when lipopeptide extracts were screened using LC-MS, they were shown to produce fengycins and surfactins (Table 7 and 9). We hypothesized that the concentration of lipopeptides produced was too low to show inhibition in the confrontation assay and/or that the presence of lipopeptides alone is not sufficient to provide inhibition.

It was found that lipopeptide extracts from some of isolates were not inhibitory against mycelial growth or conidial germinations despite the bacterial antagonists showing inhibitory 
effect against the pathogens (Table 2). It was found that these samples did not reveal any of the specifically tested lipopeptides. As previously mentioned, it is hypothesized that other antimicrobial compounds were being produced by these isolates to provide this inhibitory effect.

In summary, our results strongly suggest that lipopeptides are partly responsible for the inhibitory activity showed in vitro by Bacillus, Bacillus-related and Pseudomonas spp. toward multiple plant pathogens. Our data suggests that the inhibitory effects were not limited to the presence of the identified lipopeptides as we also noticed inhibitory effects in the absence of antimicrobial lipopeptides in the samples. We concluded that other types of bioactive compounds are present in our samples such as non-peptide antimicrobials.

Finally, this study also showed that three families of lipopeptides (fengycin, iturin, and surfactin) were produced by Bacillus spp. and Bacillus-related species. Also, two other families of lipopeptides (amphisin and putisolvin) were produced by certain Pseudomonas spp. 


\section{Chapter 5: Conclusions and future directions}

Overall, this study showed that biological control agents from Bacillus spp., Pseudomonas spp., Brevibacillus spp., Rummeliibacillus spp., Arthrobacter spp., Aminobacter spp., Brevibacterium spp., and Advenella spp. reveal antagonistic activities against plant pathogens. A total of sixteen bacterial isolates B. subtilis CU12, M9-9, B9-5, B9-7, M9-3, M94, M9-14, B9-14, IC-10, IB-2 and B9-9A and Pseudomonas isolates consisting P. moraviensis F9-6, $P$. proteolytica F9-10, $P$. moraviensis F9-11 and P. libanensis F9-13, and from other isolates A. kashmirensis IC6, exhibited inhibitory effects against the six pathogens. Furthermore, some lipopeptide extracts from these bacteria were able to inhibit mycelial growth and conidial germination of the plant pathogens. A possible explanation for these effects could be the presence of lipopeptides in all of these isolates. Previous literature indicates a strong correlation between lipopeptides and the reduction of various phytopathogens (Malfanova et al., 2012; Meena and Kanwar, 2015). We also concluded that some of the bacterial isolates exhibit an inhibitory effect because of the presence of other types of antimicrobial compounds.

Future investigation is needed to purify additional bioactive compounds from these extracts in order to identify unknown antimicrobials. These purified compounds may also be used to test their effectiveness against pathogens as well as to test their combined (potentially synergistic) effects with the lipopeptides. In addition, Bacillus and Pseudomonas spp. produce a heterogeneous mixture of homologous lipopeptides, which makes it difficult to identify subfamilies, which is why additional work is needed to identify sub groups using techniques such as nuclear magnetic resonance (NMR). This may be complemented with analytical, chromatographic, and bioassay methods with known antimicrobial compounds from these species to determine if the metabolites produced by these isolates are known or novel 
compounds. Finally, the discovery of the precise mode of action of any novel antimicrobial compounds from these bacterial isolates and in vivo testing in greenhouse or field trials would be necessary for the registration of these bacteria as biocontrol agents. Additionally, safety testing for practical application of these potential biocontrol agents will need to be performed. 


\section{Chapter 6: References}

Ajouz, S., Walker, A. S., Fabre, F., Leroux, P., Nicot, P. C., Bardin, M. 2011. Variability of Botrytis cinerea sensitivity to pyrrolnitrin, an antibiotic produced by biological control agents. Biological Control 56: 353-363.

Akpa, E., Jacques, P., Wathelet, B., Paquot, M., Fuchs, R., Budzikiewicz, H., Thonart, P. 2001. Influence of culture conditions on lipopeptide production by Bacillus subtilis. Applied Biochemical and Biotechnology 91-93: 551-561.

Arrebola, E., Sivakumar, D., Bacigalupo, R., Korsten, L. 2009. Combined application of antagonist Bacillus amyloliquefaciens and essential oils for the control of peach postharvest diseases. Crop Protection 29: 369-377.

Avilés, M., Borrero, C., Trillas, M. 2011. Review on compost as an inducer of disease suppression in plants grown in soilless culture. Issue Compost III Dynamic Plant 2: 111.

Avis, T.J. 2007. Antifungal compounds that target fungal membranes: applications in plant disease control. Canadian Journal of Plant Pathology 29: 323-329.

Axelrood, P.E., Clarke, A.M., Radley, R., Zemcov, S.J. 1996. Douglas-fir root-associated microorganisms with inhibitory activity bacterial inhibition of fungal growth 139 towards fungal plant pathogens and human bacterial pathogens. Canadian Journal of Microbiology 42: 690-700.

Bae, J., Jansky, S.H., Rouse, D.I. 2008. The potential for early generation selection to identify potato clones with resistance to Verticillium wilt. Euphytica 164: 385-393. 
Bais, H.P., Fall, R., Vivanco, J.M. 2004. Biocontrol of Bacillus subtilis against infection of Arabidopsis roots by Pseudomonas syringae is facilitated biofilm formation and surfactin production. Plant Physiology 134: 307-319.

Baker, K.F., Cook, R.J. 1974. Biological Control of Plant Pathogens. W.H. Freeman and Co., San Francisco, CA. 433 pages.

Barth, M., Hankinson, T.R., Zhuang, H., Breidt, F. 2009. Compendium of the Microbiological Spoilage of Foods and Beverages. W.H. Sperber, M.P. Doyle (eds.) pp $135-183$.

Bie, X.M., Lu, Z.X., Lu, X. 2009. Identification of fengycin homologues from Bacillus subtilis with ESI-MS/CID. Microbiology Methods 79: 272-278

Bockus, A.T., McEwen, C. M., Lokey, R.S. 2013. Form and function in cyclic peptide natural products: a pharmacokinetic perspective. Current Topics in Medicinal Chemistry 13: $821-36$.

Bojanowski, A., Avis, T.J., Pelletier, S., Tweddell, R.J. 2013. Management of potato dry rot. Postharvest Biology and Technology 84: 99-109.

Boyer, J. 2015. Sugar molds: Rhizopus spp. Diversity of Plants: https://sites.google.com/site/botany317/session-2/eukaryotes/unikonts/s2fungi/zygomycota

Bruner, S.D., Weber, T., Kohli, R.M., Schwarzer, D., Marahiel, M.A., Walsh, C.T., Stubbs, M.T. 2002. Structural basis for the cyclization of the lipopeptide antibiotic surfactin by the thioesterase domain SrfTE. Structure 10: 301-310. 
Bryk, H., Dyki, B., Sobiczewski1, P. 2004. Inhibitory Effect of Pseudomonas spp. on the Development of Botrytis cinerea and Penicillium expansum. Plant Protection Science 40: $128-134$.

Caltex Mold $\quad$ Services. 2007. Botrytis General Information. http://www.caltexmoldservices.com/Caltex/section/mold_library/botrytis/

Cameotra, S.S., Makkar, R.S. 1998. Synthesis of biosurfactants in extreme conditions. Applied Microbiology and Biotechnology 50: 520-529.

Canova, S.P., Petta, T., Reyes, L.F., Zucchi, T.D., Moraes, L.A.B., Melo, I.S. 2010. Characterization of lipopeptides from Paenibacillus sp. (IIRAC30) suppressing Rhizoctonia solani. World Journal of Microbiology and Biotechnology 26: 2241-2247.

Cawoy, H., Debois, D., Franzil, L., De Pauw, E., Thonart, P., Ongena, M. 2014. Lipopeptides as main ingredients for inhibition of fungal phytopathogens by Bacillus subtilis/amyloliquefaciens. Microbial Biotechnology 8: 281-295.

Chen, X.H., Koumaoutsi, K., Scholz, R., Borriss, R. 2009. More than anticipated-production of antibiotics and other secondary metabolites by B. amyloliquefaciens FZB42. Journal of Molecular Microbiology and Biotechnology 16: 14-24.

Chen, W., Hoitink, H. A. J., Madden, L.V. 1988. Microbial activity and biomass container media for predicting suppressiveness to damping-off caused by Pythium ultimum. Phytopathology 78: 314-322.

Christ, B. 1998. Identification of potatoes diseases in Pennsylvania. Department of plant pathology, Penn State University, US. 
Cosmina, P., Rodriguez, F., De Ferra, F., Grand i, G., Perego, M., Venema, G., Van Sinderen, D. 1993. Sequence and analysis of the genetic locus responsible for surfactin synthesis in Bacillus subtilis. Molecular Microbiology 8: 821-831.

Cotxarrera, L., Trillas-Gay, M.I., Steinberg, C., Albouvette, C. 2002. Sewage sludge compost and Trichoderma asperellum isolates to suppress Fusarium wilt of tomato. Soil Biology and Biochemistry 34: 467-476.

David, B.V. 2008. Biotechnological approaches in IPM and their impact on environment. Journal of Biopesticides 1: 1-5.

Davison, E.M., McKay, A.G. 2003. Host range of Pythium sulcatum and the effects of rotation on Pythium diseases of carrots. Australasian Plant Pathology 32:339-346.

Deepthi, K.P., Reddy, P.N. 2013. Compost teas : a potential source of antagonistic microflora against plant diseases. Journal of Cell and Life Sciences 1: 6-19.

Delfosse, E.S. 2005. Risk and ethics in biological control. Biological Control 35: 319-329.

Dionne, A., Tweddell, R.J., Antoun, H., Avis, T.J. 2012. Effect of non-aerated compost teas on damping-off pathogens of tomato. Canadian Journal of Plant Pathology 34: 51-57.

Dubern, J.F., Coppoolse, E.R., Stiekema, W.J., Bloemberg, G.V. 2008. Genetic and functional characterization of the gene cluster directing the biosynthesis of putisolvin I and II in Pseudomonas putida strain PCL1445. Microbiology 154: 2070-2083.

Duffy, B.K., Défago, G. 1999. Environmental factors modulating antibiotic and siderophore biosynthesis by Pseudomonas fluorescens biocontrol strains. Applied and Environmental Microbiology 65: 2429-2438.

Duijff, B.J., Meijer, J.W., Bakker, P.A.H.M., Schippers, B. 1993. Siderophore-mediated competition for iron and induced resistance in the suppression of fusarium wilt of 
carnation by fluorescent Pseudomonas spp. Netherland Journal of Plant Pathology 99: $277-289$.

Duitman, E.H., Hamoen, L.W., Rembold, M., Venema, G., Seitz, H., Saenger, W., Bernhard, F., Reinhardt, R., Schmidt, M., Ulrich, C., Stein, T., Leenders, F., Vater, J. 1999.The mycosubtilin synthetase of Bacillus subtilis ATCC 6633: a multifunctional hybrid between a peptide synthetase, an amino transferase, and a fatty acid synthase. Proceedings of the National Academy of Sciences of the United States of America 96: $13294-13299$.

Du Toit, L.J and Derie, M.L. 2014. First report of Pythium sulcatum causing cavity spot in processing carrot crops in the Columbia Basin of Washington State. Plant Disease 98: 427.

El Sayed, W., Abd El-Megeed, M., Abd El-Razik, A.B., Soliman, K.H., Ibrahi, S.A. 2008. Isolation and identification of phenazine-1-carboxylic acid from different Pseudomonas isolates and its biological activity against Alternaria solani. Research Journal of Agriculture and Biological Sciences 4: 892-901.

Falardeau, J., Wise, C., Novitsky, L., Avis, T.J. 2013. Ecological and mechanistic insights into the direct and indirect antimicrobial properties of Bacillus subtilis lipopeptides on plant pathogens. Journal of Chemical Ecology 39: 869-878.

Fan, Q., Tian, S.P. 2000. Postharvest biological control of Rhizopus rot on nectarine fruit by Pichia membranefaciens. Plant Disease 84: 1212-1216.

Fisher, M.C., Henk, D.A., Briggs, C.J., Brownstein, J.S., Madoff, L.C., McCraw, S.L., Gurr, S.J. 2013. Emerging fungal threats to animal, plant and ecosystem health. Nature 484: 1-18. 
Galonic, D.P., Vaillancourt, F.H., Walsh, C.T. 2006. Halogenation of unactivated carboncenters in natural product biosynthesis: trichlorination of leucine during barbamide biosynthesis. Journal of American Chemical Society 128: 3900-3901.

Gardener, B.B.M. 2004. Ecology of Bacillus and Paenibacillus spp. in agricultural systems. Phytopathology 94: 1252-1258.

Gomez-Alipzar, L. 2001. Verticillium dahliae. NC University State. PP728 pathogen profiles. http://www.cals.ncsu.edu/course/pp728/Verticillium/Vertifin.htm. Consulted on August $\underline{24^{\text {th }}, 2011 .}$.

Gross, H., Loper, J.E. 2009. Genomics of secondary metabolite production by Pseudomonas spp. Natural Product Report 26: 1408-1446.

Guenzi, E., Galli, G., Grgurina, G., Gross, D.C., Grandi, G. 1998. Characterization of the syringomycin synthetase gene cluster: a link between prokaryotic and eukaryotic peptide synthetases. Journal of Biological Chemistry 273: 32857-32863.

Haas, D., Défago, G. 2005. Biological control of soil-borne pathogens by fluorescent pseudomonads. Nature Reviews Microbiology 3: 307-319.

Hamdache, A., Lamarti, A., Aleu, J., Collado, I.G. 2011. Non-peptide metabolites from the genus Bacillus. Journal of Natural Products 74: 893-899.

Hancock, R.E.W., Chapple, D.S. 1999. Peptide Antibiotics. Antimicrobial Agents and Chemotherapy 43: 1317-1323.

Hildebrand, P.D., Braun, P.G., McRae, K.B., Lu, X. 1998. Role of the biosurfactant viscosin in broccoli head rot caused by a pectolytic strain of Pseduomonas fluorescens. Canadian Journal of Plant Pathology 20: 296-303. 
Hideaki, O., Tomohiro, Y., Chiaki, S., Yuichi, S., Naya, A. 1998. Solanapyrones, phytotoxins produced by Alternaria solani: biosynthesis and isolation of minor components. Bioscience, Biotechnology, and Biochemistry 62: 2016-2022.

Horst, K.R. 2001. Westcott's Plant Disease Hand book $6^{\text {th }}$ ed. Kluwer Academic Publishers. Boston, MA. pp. 528-529.

Hoitink, H.A.J. 1980. Compost bark, a light weight growth medium with fungicidal properties. Plant Disease 64: 142-147.

Hoitink, H.A.J., Inbar, Y., Boehm, M.J. 1991. Status of compost-amended potting mixes naturally suppressive to soilborne diseases of floricultural crops. Plant Disease 75: 869873.

Hoitink, H.A.J., Stone, A.G., Han, D.Y. 1997. Suppression of plant diseases by composts. HortScience 32: 184-187.

Hu, L.B., Shi, Z.Q., Zhang, T., Yang, Z.M. 2007. Fengycin antibiotics isolated from B-FS01 culture inhibit the growth of Fusarium moniliforme Sheldon ATCC 38932. FEMS Microbiology Letters 272: 91-98.

Inbar, Y., Boehm, M.J., Hoitink, H.A.J. 1991. Hydrolysis of fluorescein diacetate in sphagnum peat container media for predicting suppression to damping-off caused by Pythium ultimum. Soil Biology and Biochemistry 23: 479-483.

Isaac, I. 1967. Speciation in Verticillium. Annual Review of Phytopathology 41: 325-350.

Kakinuma, A., Hori, M., Isono, M., Tamura, G., Arima, K. 1969. Determination of amino acid sequence in surfactin, a crystalline peptidolipid surfactant produce by Bacillus subtilis. Agricultural and Biological Chemistry 33: 971-997. 
Kemmitt, G. 2002. Early blight of potato and tomato. The Plant Health Instructor. Dow AgroSciences, IN, USA.

Koné, S.B., Dionne, A., Tweddell, R.J., Antoun, H., Avis, T.J. 2010. Suppressive effect of non-aerated compost teas on foliar fungal pathogens of tomato. Biological Control 52: $167-173$.

Kong, Q., Chi, C., Yu, J., Shan, S., Li, Q., Li, Q., Bennett, J.W. 2014. The inhibitory effect of Bacillus megaterium on aflatoxin and cyclopiazonic acid biosynthetic pathway gene expression in Aspergillus flavus. Applied Microbiology and Biotechnology 98: 51615172.

Kuiper, I., Lagendijk, E.L., Pickford, R., Derrick, J.P., Lamers, G. E.M., Thomas-Oates, J.E., Bloemberg, G.V. 2003. Characterization of two Pseudomonas putida lipopeptide biosurfactants, putisolvin I and II, which inhibit biofilm formation and break down existing biofilms. Molecular Microbiology 51: 97-113.

Jacques, P. 2011. Surfactin and other lipopeptides from Bacillus spp. Microbiology Monographs 20:57-91.

Janisiewicz, W.J., Marchi, A. 1992. Control of storage rots on various pear cultivars with saprophytic strain of Pseudomonas syringae. Plant Disease 76: 555-560.

Janisiewicz, W.J., Jeffers, S.N. 1997. Efficacy of commercial formulation of two biofungicides for control of blue mold and gray mold of apples in cold storage. Crop Protection 16: 629-633.

Lang, S. 2002. Biological amphiphiles (microbial biosurfactants). Current Opinion in Colloid Interface Science 7: 12-20. 
Lavermicocca, P., Iacobellis, N., Simmaco, M., Graniti, A. 1997. Biological properties and spectrum of activity of Pseudomonas syringae pv. syringae toxins. Physiological and Molecular Plant Pathology 50:129-140.

Leclère, V., Béchet, M., Adam, A., Wathelet, B., Ongena, M., Thonart, P.,Jacques, P. 2005. Mycosubtilin overproduction by Bacillus subtilis BBG100 enhances the organism's antagonistic and biocontrol activities. Applied and Environmental Microbiology 71: $4577-4584$.

Leong, J. 1986. Siderophores: their biochemistry and possible role in the biocontrol of plant pathogen. Annual Review of Phytopathology 24: 187-209.

Li, B., Ravnskov, S., Xie, G., Larsen, J. 2007. Biocontrol of Pythium damping-off in cucumber by arbuscular mycorrhiza-associated bacteria from the genus Paenibacillus. BioControl 52: $863-875$.

Lin, G.H., Chen, C.L., Tschen, J.S., Tsay, S.S., Chang, Y.S., Liu, S.T. 1998. Molecular cloning and characterization of fengycin synthetase gene fen $\mathrm{B}$, from Bacillus subtilis. Journal of Bacteriology 180: 1338-1341.

Lira-de León, K.I., Ramírez-Mares, M.V., Sánchez-López, V., Ramírez-Lepe, M., SalasCoronado, R., Santos-Sánchez, N.F., Hernández-Carlos, B. 2014. Effect of crude plant extracts from some Oaxacan flora on two deleterious fungal phytopathogens and extract compatibility with a biofertilizer strain. Frontiers in Microbiology 5: 1-10.

Litterick, A.M., Harrier, L., Wallace, P., Watson, C.A., Wood, M. 2004. The role of uncomposted materials, composts, manures and compost extracts in reducing pest and disease incidence and severity in sustainable temperate agricultural and horticultural crop production a review. Critical Reviews in Plant Sciences 23: 453-479. 
Liu, X.Y., Yang, S.Z., Mu, B.Z. 2008. Isolation and characterization of a $\mathrm{C}_{12}$-lipopeptide produced by Bacillus subtilis HSO 121. Journal of Peptide Science 14: 864-875.

Loria, R. 1993. Fusarium Dry Rot of Potato. Vegetable MD online: Fact sheet. Department of Plant Pathology Cornell University, Ithaca, NY. 760 pages.

Malfanova, N., Franzil, L., Lugtenberg, B., Chebotar, V., Ongena, M. 2012. Cyclic lipopeptide profile of the plant-beneficial endophytic bacterium Bacillus subtilis HC8. Archives of Microbiology 194: 893-899.

Mandelbaum, R., Hadar, Y., Chen, Y. 1988. Composting of agricultural wastes for their use as container media: effect of heat treatments on suppression of Pythium aphanidermatum and microbial activities in substrates containing compost. Biological Wastes 26: 261274.

Marahiel, M. 1997. Protein templates of biosynthesis of peptide antibiotics. Chemical \& Biology 4: 561-567.

Markets and Markets Inc. 2013. Agricultural Inoculants Market by Type (PGPMs, BioControl Agents, Plant Resistance Stimulants), Source (Bacterial and Fungal), Mode of Application, Crop Type, Geography Global Trends Forecasts to 2019. Vancouver WA. US. http://www.marketsand markets.com/Market-Reports/agricultural-inoculants$\underline{\text { market152735696.html }}$

Martin, F., Bull, T. 2002. Biological approaches for control of root pathogens of strawberry. Phytopathology 92: 1356-1362.

Martin-Lapierre, A. 2011. Application de composts et de fumigants pour lutter contre la verticilliose (Verticillium dahliae) du fraisier. M.Sc. thesis. Département de phytologie, Université Laval. Québec, QC. pp.70-71. 
Martinez, C., Michaud, M., Bélanger, R.R., Tweddell, R.J. 2002. Identification of soils suppressive against Helminthosporium solani, the causal agent of potato silver scurf. Soil Biology and Biochemistry 34: 1861-1868.

Martinez, C., Avis, T.J., Simard, J.N., Labonté, J., Bélanger, R.R., Tweddell, R.J. 2006. The role of antibiosis in the antagonism of different bacteria towards Helminthosporium solani, the causal agent of potato silver scurf. Phytoprotection 87: 69-67.

Meena, K.R., Kanwar, S.S. 2015. Lipopeptides as the antifungal and antibacterial agents: Applications in food safety and therapeutics. BioMed Research International http://dx.doi.org/10.1155/2015/473050.

Mezaache-Aichour, S., Guechi, A., Nicklin, J., Drider, D., Prevost, H., Strange, R.N. 2012. Isolation, identification, and antimicrobial activity of pseudomonads isolated from the rhizosphere of potatoes growing in Algeria. Journal of Plant Pathology 94: 89-98.

Mishra, R.K., Prakash, O., Tiwari, A.K., Pandey, A., Alam, M., Dikshit, A. 2011. Culture filtrate antibiosis of plant growth promoting rhizobacteria PGPRs against phytopathogens infecting medicinal and aromatic plants. International Journal of Research in Biological Sciences 1: 45-51.

Mondol, M.A.M., Shin, H.J., Islam, M.T. 2013. Diversity of secondary metabolites from marine Bacillus species: chemistry and biological activity. Marine Drugs 11: 2846-2872.

Montesinos, E. 2007. Antimicrobial peptides and plant disease control. FEMS Microbiology Letters 270: 1-11.

Mott, K.A., Takemoto, J.Y. 1989. Syringomycin, bacterial of phytotoxin, closes stomata. Plant Physiology 90: 1435-1439. 
Moyne, A.L., Cleveland, T.E., Tuzun, S. 2004. Molecular characterization and analysis of the operon encoding the antifungal lipopeptide bacillomycin D. FEMS Microbiology Letters 234: 43-49.

Mulet, M., Lalucat, J., García-Valdés, E. 2010. DNA sequence-based analysis of the Pseudomonas species. Environmental Microbiology 12: 1513-1530.

Nakajima, M., Akutsu, K. 2013. Virulence factors of Botrytis cinerea. Journal of General Plant Pathology 80: 15-23.

National Center for Biotechnology Information (NCBI). 2015. http://www.ncbi.nlm.nih.gov/Taxonomy/Browser/

Nielsen, T.H., Sørensen, D., Tobiasen, C., Andersen, J.B., Christophersen, C., Givskov, M., Sørensen, J. 2002. Antibiotic and biosurfactant properties of cyclic lipopeptides produced by fluorescent Pseudomonas spp. from sugar beet rhizosphere. Applied and Environmental Microbiology 68: 3416-3423.

Nielsen, T.H., Sjøholm, O.R., Sørensen, J. 2009. Multiple physiological states of a Pseudomonas fluorescens DR54 biocontrol inoculant monitored by a new flow cytometry protocol. FEMS Microbiology Ecology 67: 479-490.

Niisawa, C., Oka, S.I., Kodama, H., Hirai, M., Kumagai, Y., Mori, K., Miyamoto, H. 2008. Microbial analysis of a composted product of marine animal resources and isolation of bacteria antagonistic to a plant pathogen from the compost. Journal of General and Applied Microbiology 54: 149-158.

Niu, D.D., Wang, C.J., Guo, Y.H., Jiang, C.H., Zhang, W.Z., Wang, Y., Guo, J.H. 2011. AR156 induces resistance in tomato with induction and priming of defence response. Biocontrol Science and Technology 22: 991-1004. 
Njoroge, C., Kabir, Z., Martin, N., Subbarao, V. 2009. Comparison of crop rotation for Verticillium wilt management and effect on Pythium species in conventional and organic strawberry production. Plant Disease 93: 519-527.

On, A., Wong, F., Ko, Q., Tweddell, R.J., Antoun, H., Avis, T.J. 2015. Antifungal effects of compost tea microorganisms on tomato pathogens. Biological Control 80: 63-69.

Ongena, M., Jacques, P. 2008. Bacillus lipopeptides: versatile weapons for plant disease biocontrol. Trends in Microbiology 16: 115-125.

Ongena, M., Jacques, P., Toure, Y., Destain, J., Jabrane, A., Thonart, P. 2005. Involvement of fengycin-type lipopeptides in the multifaceted biocontrol potential of Bacillus subtilis. Applied Microbiology and Biotechnology 69: 29-38.Pal, K.K., McSpadden Gardener, B. 2006. Biological control of plant pathogens. Plant Health Instructor DOI: 10.1094/PHI-A-2006-1117-02.

Palleroni, N.J. 1993. Pseudomonas classification. A new case history in the taxonomy of Gramnegative bacteria. Antonie Van Leeuwenhoek 64: 231-251.

Pecci, Y., Rivardo, F., Martinotti, M.G., Allegrone, G. 2010. LC/ESI-MS/MS characterisation of lipopeptide biosurfactants produced by the Bacillus licheniformis V9T14 strain. Journal of Mass Spectrometry 45: 772-778.

Pyoung, I.K., Ryu, J., Kim, Y.H., Chi, Y.T. 2010. Production of biosurfactant lipopeptides iturin A, fengycin and surfactin from Bacillus subtilis CMB32 for control of Colletotrichum gloespriodes. Journal of Microbiology and Biotechnology 20: 138-145.

Raaijmakers, J.M, De Bruijn, I., De Kock, M.J.D. 2006. Cyclic lipopeptide production by plant associated Pseudomonas species: diversity, activity, biosynthesis and regulation. Molecular Plant-Microbe Interactions 19: 699-710. 
Raaijmakers, J.M., De Bruijn, I., Nybroe, O., Ongena, M. 2010. Natural functions of lipopeptides from Bacillus and Pseudomonas: more than surfactants and antibiotics. FEMS Microbiology Reviews 34: 1037-1062.

Ripperger, H., Seifert, K., Romer, A., Rullkotter, J. 1975. Isolierung von Diacetoxyscirpenol aus Fusarium solani var. coeruleum. Phytochemistry 14: 2298-2299.

\section{Romero, D., De Vicente, A., Rakotoaly, R., Dufour, S., Veening, J., Arrebola, E., Cazorlam} F.M., Kuipers, O.P., Paquot, M., Pérez-García, A. 2007. The iturin and fengycin families of lipopeptides are key factors in antagonism of Bacillus subtilis toward Podosphaera fusca. Molecular Plant-Microbe Interactions 20: 430-440.

Roongsawang, N., Washio, K., Morikawa, M. 2011. Diversity of nonribosomal peptide synthetases involved in the biosynthesis of lipopeptide biosurfactants. International Journal of Molecular Sciences 12: 141-172.

Rückert, C., Blom, J., Chen, X., Reva, O., Borriss, R. 2011. Genome sequence of $B$. amyloliquefaciens type strain DSM7T reveals differences to plant-associated $B$. amyloliquefaciens FZB42. Journal of Biotechnology 155: 78-85.

Sayyed, R.Z., Patel, P.R. 2011. Biocontrol potential of siderophore producing heavy metal resistant Alcaligenes spp. and Acinetobacter spp. vis-à-vis organophosphorus fungicide. Indian Journal of Microbiology 51: 266-272.

Scheuerell, S., Mahaffee, W. 2002. Compost tea: principles and prospects for plant disease control. Compost Science and Utilization 10: 313-338.

Schneider, T., Gries, K., Josten, M., Wiedemann, I., Pelzer, S., Labischinski, H., Sahl, H. G. 2009. The lipopeptide antibiotic friulimicin B inhibits cell wall biosynthesis through 
complex formation with bactoprenol phosphate. Antimicrobial Agents and Chemotherapy 53: 1610-1618.

Segre, A., Bachmann, R.C., Ballio, A. 1989. The structure of syringomycins A1, E and G. FEBS Letter 255: 27-31.

Sharma, N., Gupta, A., Gautam, N. 2014. Characterization of bacteriocin like inhibitory substance produced by a new strain Brevibacillus borstelensis AG1 Isolated from “Marcha”. Brazilian Journal of Microbiology 45: 1007-1015.

Shu, H.Y., Lin, G.H., Wu, Y.C., Tschen, J.S., Liu, S.T. 2002. Amino acids activated by fengycin synthetase FenE. Biochemical and Biophysical Research Communications 292: 789-793.

Sokolova, G.D., Voznesenskiü, V.N. 2011. Biosynthesis of 4,15-diacetylnivalenol by Fusarium sambucinum Fuckel var. minus. Prikladnaia biokhimiia i mikrobiologiia 47: 46-49.

Sonnenbichler, J., Guillaumin, J.J., Peipp, H., Schwarz, D. 1997. Secondary metabolites from dual cultures of genetically different Armillaria isolates. European Journal of Forest Pathology 27: 241-249.

Sorensen, K.N., Kim, K.H., Takemoto, J.Y. 1996. In vitro antifungal and fungicidal activities and erythrocyte toxicities of cyclic lipodepsinonapeptides produced by Pseudomonas syringae pv. syringae. Antimicrobial Agents and Chemotherapy 40: 2710-2713.

Sorensen, D., Nielsen, T. H. 2001. Cyclic lipoundecapeptide amphisin. Acta Crystallographica Section C 57:1123-1124.

Stein, T. 2005. Bacillus subtilis antibiotics: structures, syntheses and specific functions. Molecular Microbiology 56: 845-857. 
Stevenson, W.R., Loria, R., Franc, G.D., Weingartner, D.P. 2001. Compendium of potato diseases, 2nd Edition. APS Press.

Stevenson, W.R. 1993. Management of early blight and late blight. In Potato Health Management. Rowe, R.C. (ed), APS Press, St. Paul, MN Pages 141 -147.

Takemoto, J.Y., Brand, G., Kaulin, Y.A., Malev, V.V., Schagina, L.V., Blasko, K. 2003. The syringomycins: lipodepsipeptide pore formers from plant bacterium, Pseudomonas syringae. In pore forming peptides and protein toxins. G. Menestrina et al. (eds.), pp. 260-271. Taylor \& Francis, London.

Tehrani, A.S., Disfani, F.A., Hedjaroud, G.A., Mohammadi, M. 2001. Antagonistic effects of several bacteria on Verticillium dahliae the causal agent of cotton wilt. Mededelingen (Rijksuniversiteit te Gent. Fakulteit van de Landbouwkundige en Toegepaste Biologische Wetenschappen) 66: 95-101.

Termorshuizen, A.J., Jeger, M.J. 2008. Strategies of soil borne plant pathogenic fungi in relationship to disease suppression. Fungal Ecology 1: 108-114.

Thaniyavarn, J., Roongsawang, N., Kameyama, T., Haruki, M., Imanaka, T., Morikawa, M., Kanaya, S. 2003. Production and characterization of biosurfactants from Bacillus licheniformis F2.2. Bioscience, Biotechnology, and Biochemistry 67: 1239-1244

Thimon, L., Peypoux, F., Wallach, J., Michel, G. 1995. Effect of the lipopeptide antibiotic, iturin A, on morphology and membrane ultrastructure of yeast cell. FEMS Microbiology Letters 128: 101-106.

Toxic Action Center. 2012. The problem with pesticides. http://www.toxicsaction.org/problems-and-solutions/pesticide

Trivedi, P.C. 2007. Biocontrol of Plant Disease. Aavishkar Publishers, Jaipur, India. 438 pages. 
Trotel-Aziz, P., Couderchet, M., Biagianti, S., Aziz, A. 2008. Characterization of new bacterial biocontrol agents Acinetobacter, Bacillus, Pantoea and Pseudomonas spp. mediating grapevine resistance against Botrytis cinerea. Environmental and Experimental Botany 64: 21-32.

Tsuge, K., Akiyama, T., Shoda, M. 2001. Cloning, sequencing, and characterization of the iturin A operon. Journal of Bacteriology 183: 6265-6273.

Vaishampayan, P., Miyashita, M., Ohnishi, A., Satomi, M., Rooney, A., La Duc, M.T., Venkateswaran, K. 2009. Description of Rummeliibacillus stabekisii gen. nov., sp. nov. and reclassification of Bacillus pycnus. International Journal of Systematic and Evolutionary Microbiology 59: 1094-1099.

Van Loon, L.C., Glick, B.R. 2004. Increased plant fitness by rhizobacteria. In: Sandermann H, ed. Molecular ecotoxicology of plants, Ecological Studies 170. Berlin, Heidelberg: SpringerVerlag 177-205.

Velázquez, E., de Miguel, T., Poza, M., Rivas, R., Rosselló-Mora, R., Villa, T. G. 2004. Paenibacillus favisporous sp. nov., a xylanolytic bacterium isolated from cow faeces. International Journal of Systematic and Evolutionary Microbiology 54:59-64.

Velho, R.V, Medina, L.F.C., Segalin, J., Brandelli, A. 2011. Production of lipopeptides among Bacillus strains showing growth inhibition of phytopathogenic fungi. Folia Microbiologica 56: 297-303.

Vurro, M., Bonciani, B., Vannacci, G. 2010. Emerging infectious diseases of crop plants in developing countries: impact on agriculture and socio-economic consequences. Food Security 2: 113-132. 
Wang, J., Liu, B., Liu, G., Chen, Q., Zhu, Y., Chen, Z., Che, J. 2015. Genome sequence of Brevibacillus formosus $\mathrm{F} 12 \mathrm{~T}$ for a genome-sequencing project for genomic taxonomy and phylogenomics of Bacillus-like bacteria. Genome Announcements 3: 4-5.

Wang, J., Haddad, N.I.A., Yang, S.Z., Mu, B.Z. 2010. Structural characterization of lipopeptides from Brevibacillus brevis HOB1. Applied Biochemistry and Biotechnology 160: 812-821.

Wilkinson, R., Fitzgerald, G. 1997. Public perceptions of biological control of rabbits in New Zealand: some ethical issues and practical issues. Agriculture and Human Values 14: 273-282.

Wise, C., Novitsky, L., Tsopmo, A., Avis, T.J. 2012. Production and antimicrobial activity of 3-hydroxypropionaldehyde from Bacillus subtilis strain CU12. Journal of Chemical Ecology 38: 1521-1527.

Wu, C.Y., Chen, C.L., Lee, Y.H., Cheng, Y.C., Wu, Y.C., Shu, H.Y. 2007. Non ribosomal synthesis of fengycin on an enzyme complex formed by fengycin synthetases. Journal of Biological Chemistry 282: 5608- 5616.

Yuan, J., Raza, W., Shen, Q., Huang, Q. 2012. Antifungal activity of Bacillus amyloliquefaciens NJN-6 volatile compounds against Fusarium oxysporum f. sp. cubense. Applied and Environmental Microbiology 78:5942-5944.

Zamski, E., Peretz, I. 1995. Cavity spot of carrots: II. Cell- wall-degrading enzymes secreted by Pythium and pathogen-related proteins produced by the root cells. Annals of Applied Biology 128: 195-207. 
Zhang, S., Wang, Y., Meng, L., Li, J., Zhao, X., Cao, X., Li, J. 2012. Isolation and characterization of antifungal lipopeptides produced by endophytic Bacillus amyloliquefaciens TF28. African Journal of Microbiology Research 6: 1747-1755.

Zhou, X., Lu, Z., Lv, F., Zhao, H., Wang, Y., Bie, X. 2011. Antagonistic action of Bacillus subtilis strain fmbj on the postharvest pathogen Rhizopus stolonifer. Journal of Food Science 76: M254-259.

Zintani, G. 2005. Compost in the 20th Century: A tool to control plant diseases in nursery and vegetable crops. HortTechnology 15: 61-66. 


\section{Appendix I}
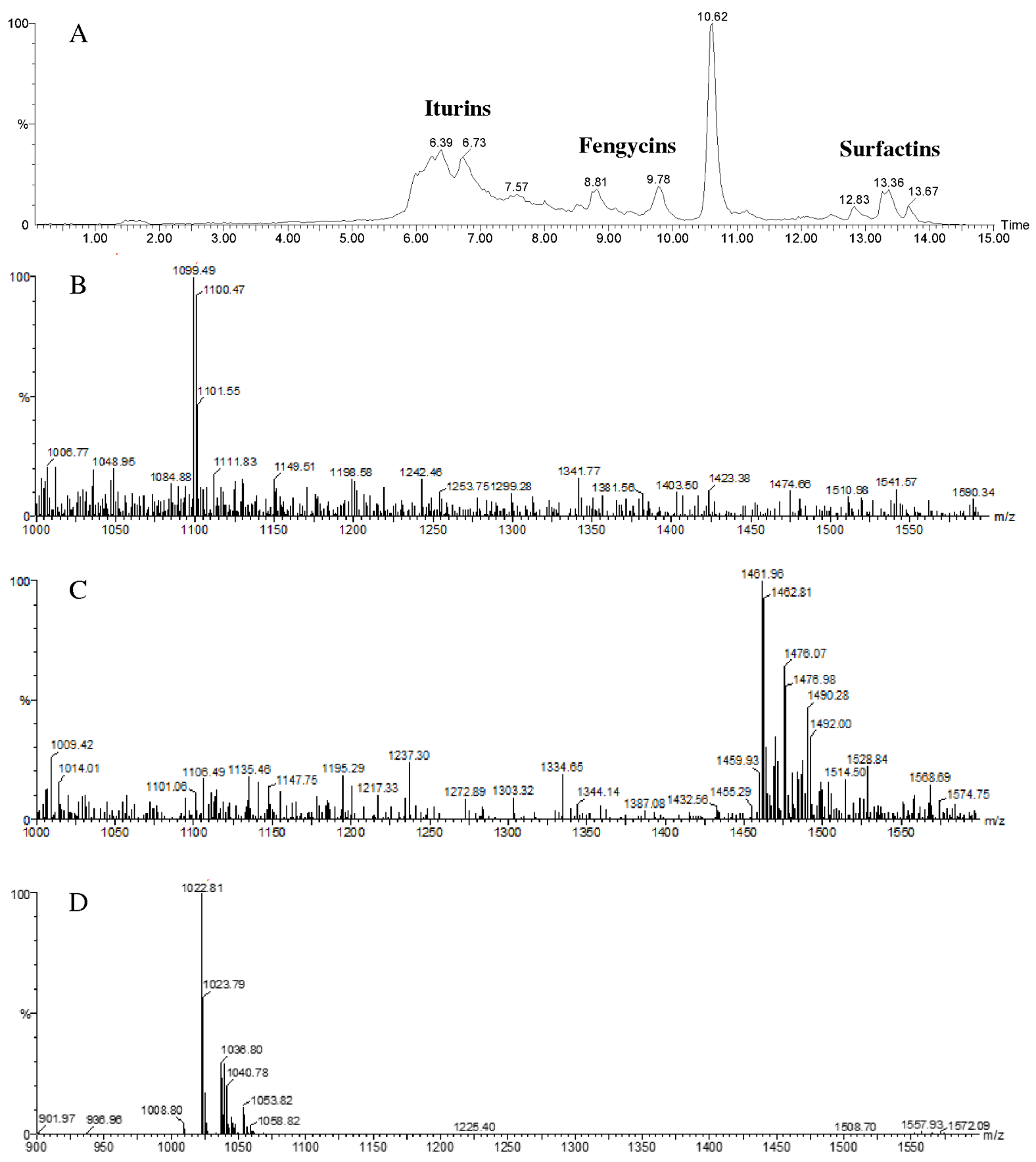

Figure A1. Lipopeptides families produced by Bacillus subtilis CU12. A. Chromatogram showing the three families of lipopeptides; B. Mass spectrum iturin, $m / z=1084$ and 1099; C. Mass spectrum of fengycins, $m / z=1462,1476,1490$; D. Mass spectrum of $\operatorname{surfactin} m / z=1008$, $1022,1036$. 

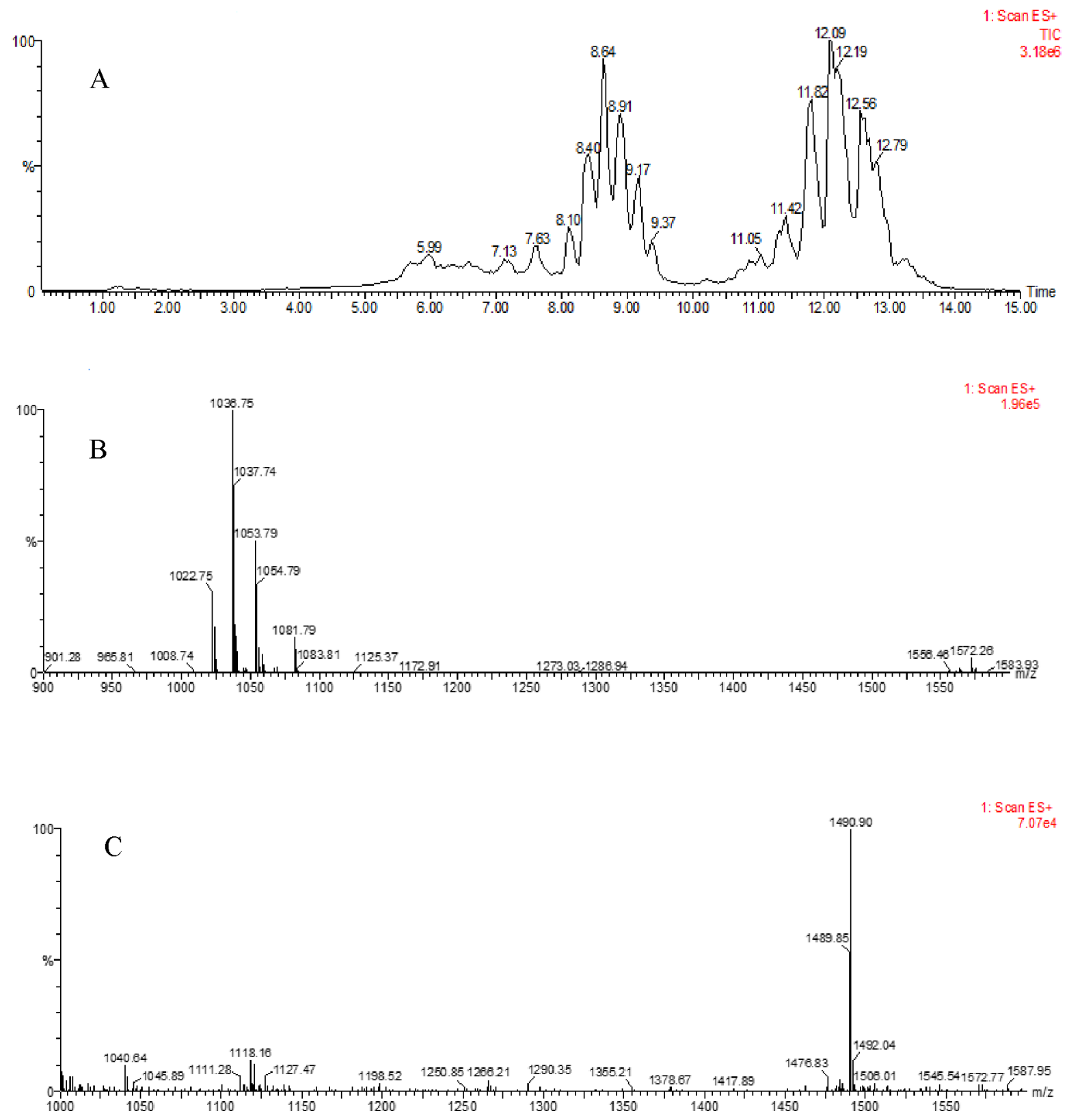

Figure A2. Lipopeptides families produced by Bacillus megaterium B9-9B. A. Chromatogram showing the two families of lipopeptides; B. Mass spectrum surfactin, $m / z=1008,1022,1036$; C. Mass spectrum of fengycin, $m / z=1476,1490,1492,1506$. 

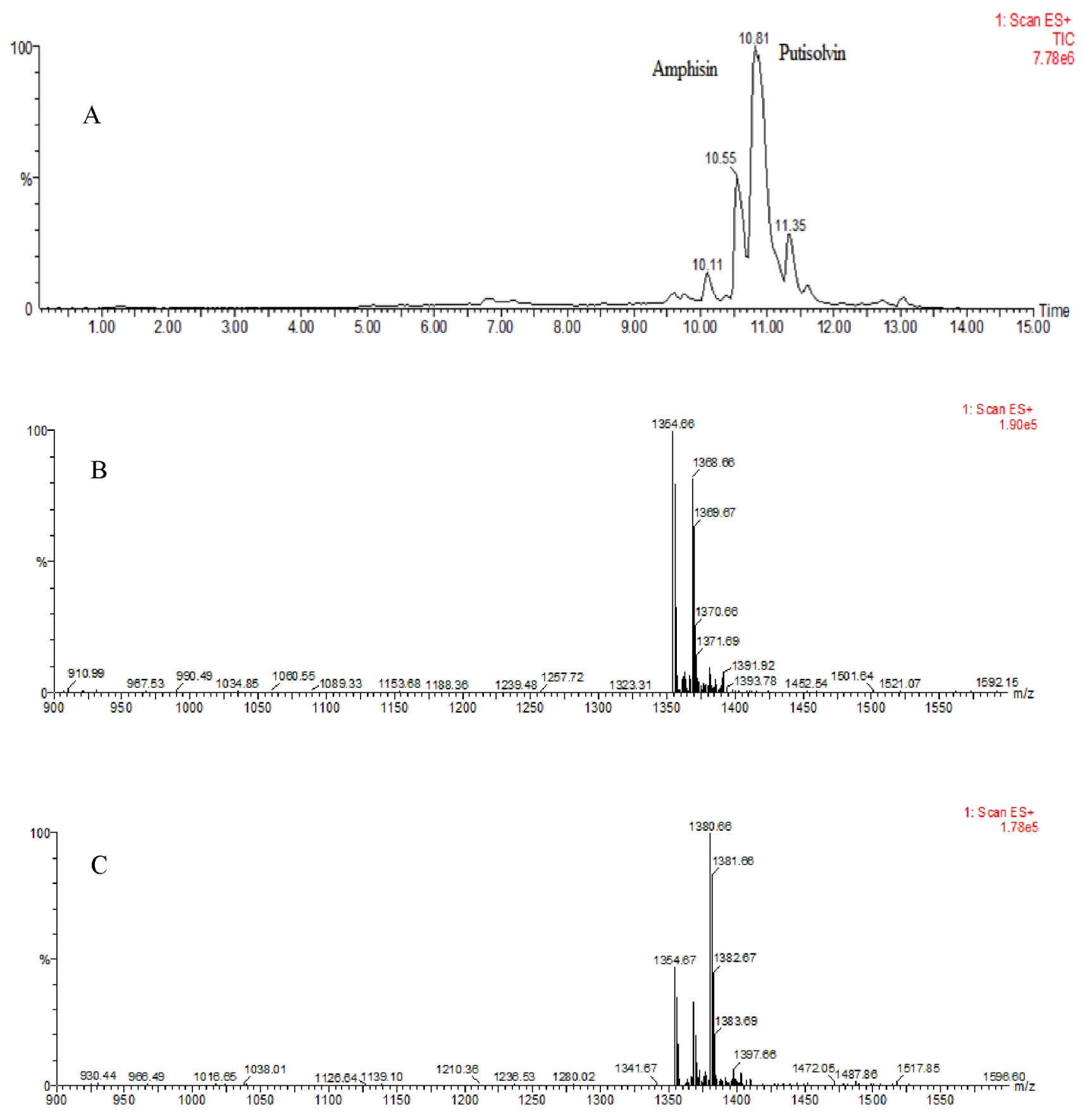

Figure A3. Lipopeptides families produced by Pseudomonas moraviensis F9-11. A. Chromatogram showing the three families of lipopeptides; B. Mass spectrum amphisin, $\mathrm{m} / \mathrm{z}=$ 1340, 1354, 1368, 1382; C. Mass spectrum of putisolvin, $m / z=1383$ and 1397. 